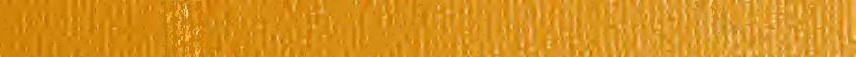

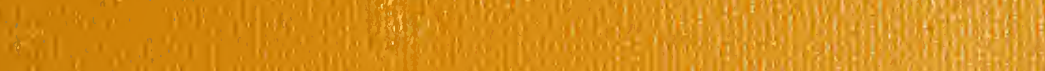

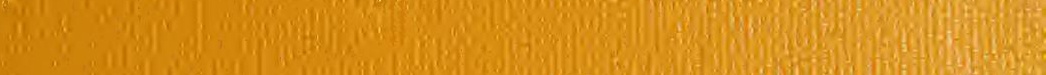

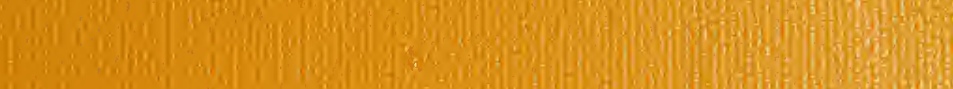

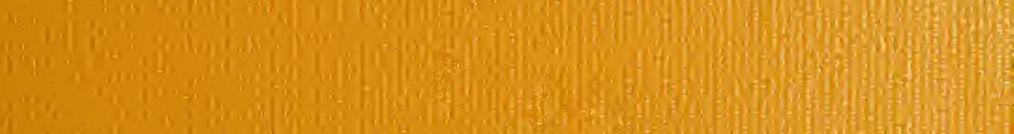

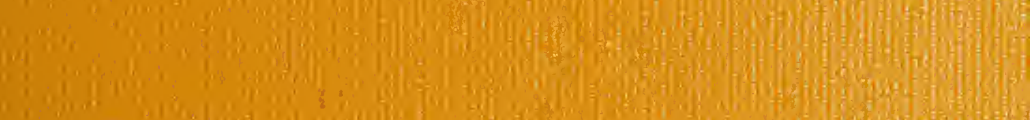
in

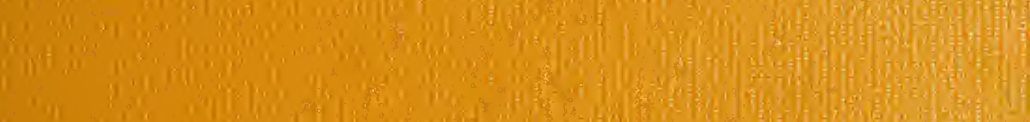
(1,

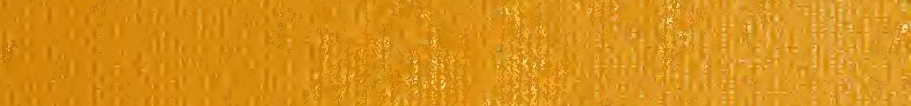
ang an

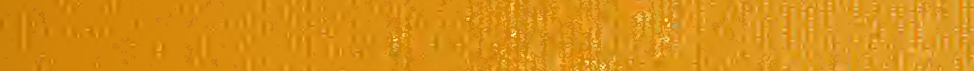
I

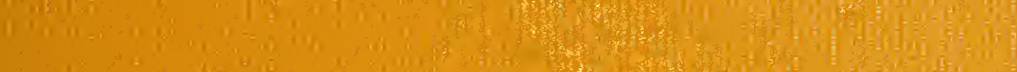

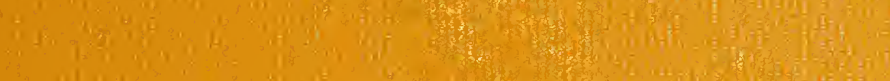
1. 3.

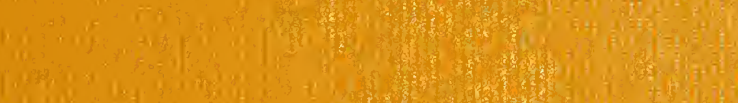

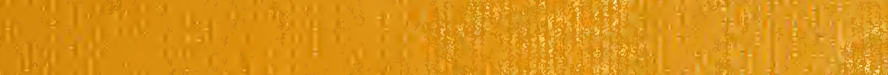
(1), ats. (1. 3rix

13 3.

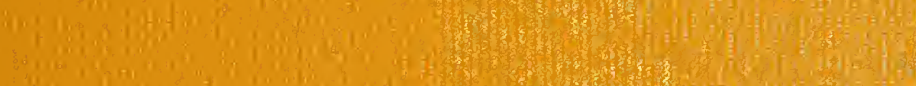

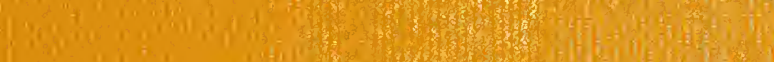

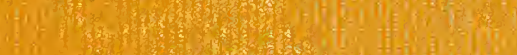

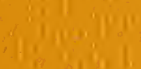

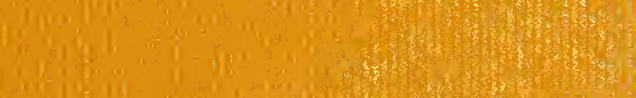
$t^{2}$

(10.)

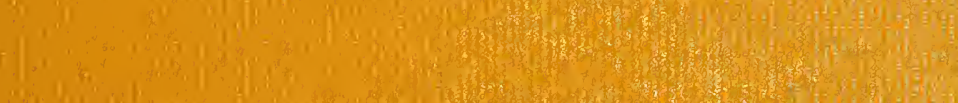
4. I. : A.

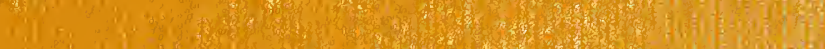

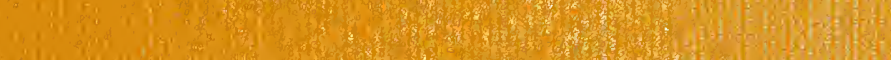

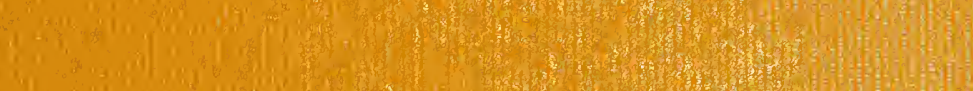

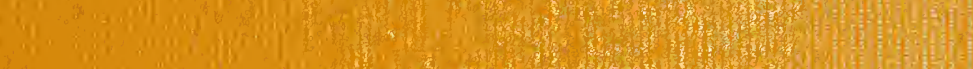

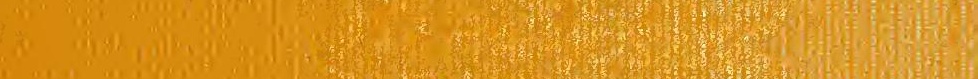
Ant: 
Digitized by the Internet Archive in 2011 with funding from

LYRASIS members and Sloan Foundation 




\title{
TOBACCO SUBSTATION AT WINDSOR REPORT FOR 1930
}

\author{
P. J. ANDERSON, T. R. SWANBACK, O. E. STREET \\ AND OTHERS
}

\section{Crmmertinut}

\section{Anrinultural Extarintent Statinn}

\section{R.?}

bulletins of this station are mailed free to citizens of Connecticut ply for them and to other applicants as far as the editions permit. 


\section{BOARD OF CONTROL}

His Excellency, Governor Wilbur L. Cross, extofficio, President

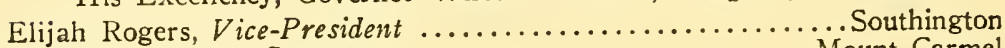

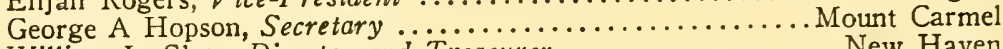
William L. Slate, Director and Treasurer ............... New Haven

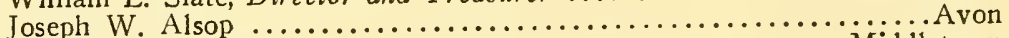

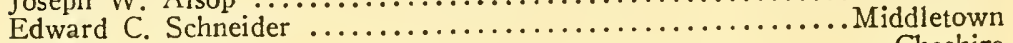

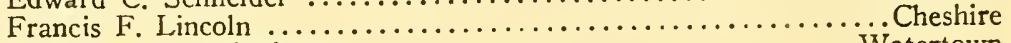
S. McLean Buckingham ......................................

\section{STAFF}

Administration. William L. Slate, B.Sc., Director and Treasurer. Miss L. M. BRAutLecnit, Bookkeeper and Librarian. MISS DOROTHY AMRINE, B.LITT, Editor.

G. E. GRAHAM, In Charge of Buildings and Grounds.

Analytical

Chemistry.

E. M. BaIley, Ph.D., Chemist in Charge.

C. E. Shepard

OWEN L. NolAn

W. T. Mathis

DAVID C. WALDEN, B.S.

Miss Harriet C. YALE, General Assistant.

Fran K C. SHeldon, Laboratory Assistant.

V. L. CHURCHILl, Sampling Agent.

Mrs. A. B. Vosburgh, Secretary.

Biochemistry.

H. B. VICKERY, РH.D., Biochemist in Charge.

George W. PuCHer, PH.D., Assistant Brochemist.

Mrs. Helen Cannon Cronin, B.S., Dietitian.

Botany.

G. P. Clinton, Sc.D., Botanist in Charge.

E. M. STODDARD, B.S., P omologist.

Miss Fiorence A. MCCORMick, PH.D., Pathologist.

A. A. Dunlar, PH.D., Assistant Mycologist.

A. D. McDon nel, General Assistant.

Mrs. W. W. Kelsey, Secretary.

Entomology.

W. E. BRitton, PH.D., D.Sc., Entomologist in Charge, State Entomologist.

B. H. WALDEN, B.Agr.

$\left.\begin{array}{l}\text { M. P. ZAPPE, B.S. } \\ \text { PHILIP GARMAN, PH.D. } \\ \text { ROGER B. FRIEND, PH.D. }\end{array}\right\}$ Assistant Entomologists.

ROGER B. FrIEND, PH.D. Deputy in Charge of Gipsy Moth Work.

JoH T. AsHWORTH, Deputy in Charge of Guito Elimination.

J. P. JoHnson, B.S., Deputy in Charge of Asiatic and Japanese Beetle Quarantines.

Mrs, Gladys Brooke, B.A., Secretary.

Forestry.

Walter O. Filley, Forester in Charge.

H. W. Нıсоск, M.F., Assistant Forester.

J. E. RILEY, JR., M.F., In Charge of Blister Rust Control.

Miss Pauline A. Merchant, Secretary.

Plant Breeding. Donald F. Jones, Sc.D., Geneticist in Charge.

W. R. Singleton, Sc.D., Assistant Geneticist.

Lawrence C. Curtis, B.S., Assistant.

Mrs. Catherine R. Miller, M.A., Secretary.

Soils.

M. F. Morgan, M.S., Agrononist in Charge.

H. G. M. JAcoBson, M.S., Assistant Agronomist.

Herbert A. Lunt, Ph.D., Assistant in Forest Soils.

Dwight B. Downs, General Assistant.

Tobacco Substation at Windsor.

Paul J. Anderson, Ph.D., Pathologist in Charge.

T. R. SWAN BACK, M.S., Agronomist.

O. E. Street, M.S., Plant Physiolooist.

Miss DoRothy Lenard, Secretary. 


\section{CONTENTS}

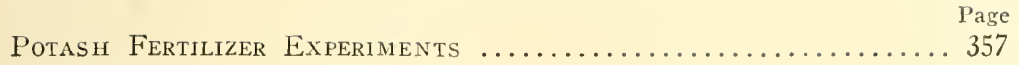

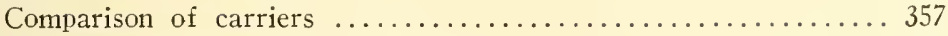

Sulfate, carbonate and nitrate of potash ............ 357

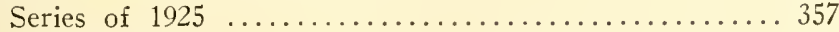

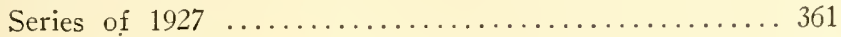

Summary and discussion $\ldots \ldots \ldots \ldots \ldots \ldots \ldots \ldots \ldots \ldots \ldots$

Ground tobacco stems as a source of potash $\ldots \ldots \ldots \ldots . \ldots 363$

Chemical analyses of tobacco on stems plots ......... 364

Cotton hull ashes as a source of potash ............. 366

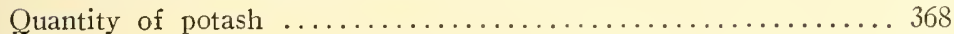

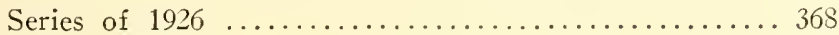

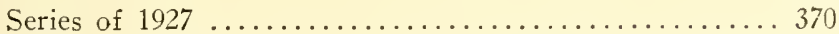

Effect of the quantity of potash applied in the fertilizer on the percentage of potash, lime and magnesia in the

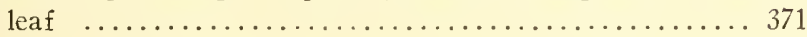

Nitrogen Fertilizer Experiments ............................. 374

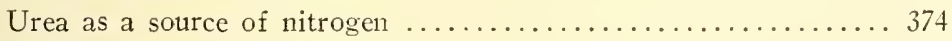

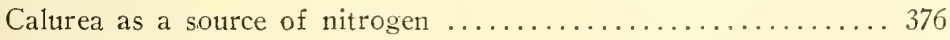

Nitrophoska tests ................................. 377

Comparison of nitrate of soda and nitrate of lime as a mineral source of nitrogen ............................ 379

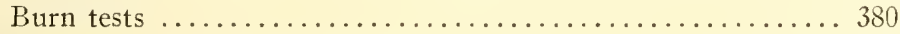

Fractional Application of Fertilizer ................. 331

Manure as a Supplement to Commercial Fertilizer .......... 384

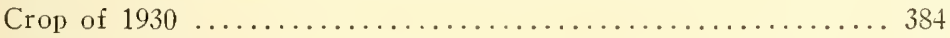

Black rootrot on the manure plots ................... 385

Increase in soil organic matter from use of manure ......... 386

Increase in water-holding capacity of soil $\ldots \ldots \ldots \ldots \ldots \ldots . \ldots 387$

Effect of manure on the burn ...................... 387

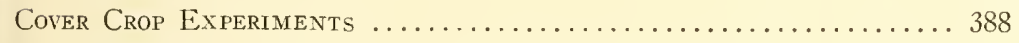

The Relation of Magnesia to the Burning Qualities of Cigar LEAF ToBAcco ............................ 391 
Eritect or Toprise Page

Effect of Topping and Suchering on Development of the Tobacco

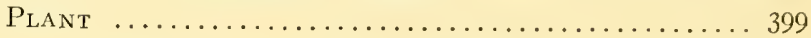

Influence of Plant Trimaing on Weight of Seeds $\ldots \ldots \ldots \ldots \ldots \ldots 406$

Curing Experiments $\ldots \ldots \ldots \ldots \ldots \ldots \ldots \ldots \ldots \ldots \ldots \ldots \ldots \ldots \ldots$

Tobacco Insect Studies in $1930 \ldots \ldots \ldots \ldots \ldots \ldots \ldots \ldots \ldots \ldots \ldots \ldots \ldots \ldots \ldots \ldots \ldots$

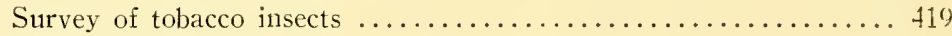

Experiments with insecticides $\ldots \ldots \ldots \ldots \ldots \ldots \ldots \ldots \ldots \ldots . \ldots 421$

Miscellaneous observations on tobacco insects ............ 424

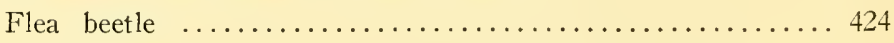

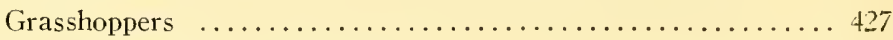

Late infestation of wireworms ................. 429

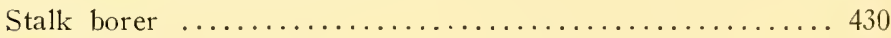

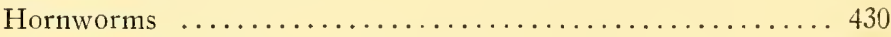

Paris green injury to tobacco $\ldots \ldots \ldots \ldots \ldots \ldots \ldots \ldots \ldots \ldots \ldots \ldots \ldots \ldots \ldots$

Fertilizer Losses Through Leaching Measured by Lysimeter

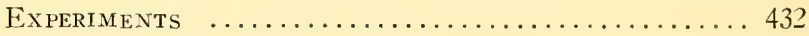

The Use of Coke in Heating Tobacco Sheds ............... 442

Fire-curing Tests on Stalk Tobacco ........................ 445

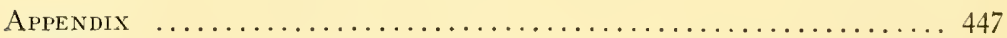




\section{TOBACCO SUBSTATION AT WINDSOR REPORT FOR $1930^{1}$}

The season of 1930 was generally favorable for growth of tobacco, and satisfactory progress has been made on most of the projects under way. The temperature during the growing season was above average and the rainfall sufficient and well distributed up to the latter part of July. The accompanying table, which gives the rainfall by 10-day periods during the growing seasons of the last two years, shows how much more favorable were the distributtion and amount, than in 1929.

Table 1. Distribution of Rainfall in Inches at the Tobacco Substation, Windsor, 1929 and 1930

By 10-day periods

\begin{tabular}{|c|c|c|c|c|c|c|c|c|c|c|}
\hline \multirow[b]{2}{*}{ Year } & & & & & & \multirow{2}{*}{$\overbrace{1-10 \quad 11-20}^{\text {Augtust }}$} \\
\hline & $1-10$ & $11-20$ & $21-31$ & $1-10$ & 11.20 & $21-30$ & -10 & $11-20$ & $21-31$ & \\
\hline & 1.4 & 1.56 & 1.7 & 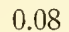 & 0.03 & & & 0.4 & & $2.73 \quad 2.13$ \\
\hline & 0.43 & 2.01 & 2.04 & 2.38 & 0.73 & 0.62 & 0.93 & 0.69 & 1.01 & 0.63 \\
\hline
\end{tabular}

By months

$\begin{array}{lcccc} & \text { May } & \text { June } & \text { July } & \text { August } \\ 1929 & 4.79 & 1.67 & 0.98 & 4.86 \\ 1930 & 4.48 & 3.73 & 2.63 & 2.16 \\ \text { Mean }^{2} & 3.55 & 3.06 & 4.31 & 2.93\end{array}$

The weather in 1930 resulted in unusually rapid growth and development of the plants, and it was found necessary to start harvesting before August 1, an unprecedented occurrence at the Station. During the latter half of July, however, the rain was insufficient and the unusually hot days of low humidity caused tobacco on light lands to wilt badly. In many fields the lower leaves were spoiled by burning on the hot sands. Serious damage on the Station farm from this source was avoided by irrigating twice during the drought. The installation of this irrigation system, which consists of a fire hydrant and 700 feet of ordinary fire hose, was the most notable addition to our equipment during the year.

Although the Connecticut Valley was visited by five destructive hail storms within the season, the crop on the experiment station farm was untouched. The loss from hail to the crop throughout the Valley approached but did not equal that of 1929.

Fertilizer experiments on broadleaf tobacco were begun this year on the Farnham farm at East Windsor Hill, under the super-

\footnotetext{
${ }^{1}$ For bibliographical purposes all material should be credited to $\mathrm{P}$. J. Anderson, T. R. Swanback and O. E. Street, unless otherwise indicated.

${ }^{2}$ Hartford records for the past 57 years.
} 
vision of J. S. Owens, Extension Agronomist of the Connecticut Agricultural College. The tobacco on these plots was destroyed by hail and therefore no results were recorded.

Two assistants were added temporarily to the scientific staff during the summer. Donald S. Lacroix, under the direction of the Department of Entomology, spent three months in a survey and investigation of insects that attack tobacco. His summary of the work accomplished is published on page 419 of this bulletin. Dr. Th. Berthold, until recently tobacco expert of the province of Brandenberg, Germany, was on our staff throughout the summer under the direction of the Department of Plant Breeding. He continued the breeding work with shade tobacco and conducted investigations along other lines, some of which are reported on pages 319 and 406 of this bulletin.

The purchase of a small field, the Mellon tract, adjacent to the Station farm furnished an opportunity for conducting experiments with phosphoric acid on land that had not grown tobacco previously, the only condition in which phosphatic fertilizers seem to be necessary. Leasing another field, the Pomeroy tract, directly across the road from the station farm also furnished an opportunity for a comprehensive set of field plots on which the use of magnesian lime is under investigation.

Dr. Vickery and Dr. Pucher of the Department of Biochemistry have continued their studies of the tobacco plant and have made valuable contributions to our knowledge of the organic acids of tobacco and of the changes in the nitrogenous compounds during curing. The work is published in Bulletins 323 and 324. Important investigations conducted by the Department of Soils on nutrition of tobacco have been published recently in Bulletin 320, "The Soils of Connecticut."

A project on "Improvement of Havana Seed Strains," which has been inactive since 1926, has been resumed on a larger scale through the interest and financial support of three cigar manufacturing corporations, Bayuk Cigars, Incorporated, the -General Cigar Company, and the Congress Cigar Company, under the direct supervision of W. H. Hatheway. We are coöperating with the Office of Tobacco Investigations, United States Department of Agriculture, in a project under the supervision of C. V. Kightlinger to find or develop strains of Havana Seed tobacco of satisfactory quality that are resistant to black rootrot.

Fertilizer experiments with special reference to the use of manure for shade tobacco are being conducted in West Granby in coöperation with the growers F. S. Holcomb and Son and with the American Cigar Company.

The following pages contain progress reports on projects of the Tobacco Substation that are sufficiently advanced to warrant publication of results now obtained. 


\section{POTASH FERTILIZER EXPERIMENTS}

The object of all the potash fertilizer experiments continued in 1930 is to determine, (1) which carriers of potash are best and (2) which is the optimum quantity to apply. Each involved the use of a different set of field plots and the two are discussed separately.

\section{Comparison of Carriers}

Potash is ordinarily supplied in the tobacco fertilizer mixture as the sulfate, nitrate or carbonate of potash. Double sulfate of potash-magnesia has been used to some extent. The conclusion of a six-year experiment on this last salt was given in the Report of the Tobacco Substation for 1928. Carbonate of potash may also be supplied in cottonhull ashes. Another source of potash is tobacco stems, originally applied in the unground condition separate from the fertilizer, but now supplied in a finely ground condition suitable for incorporation with the other ingredients.

\section{Sulfate, Carbonate and Nitrate of Potash}

In order to compare these carriers or combinations of them a series of ten plots was started in 1925 (designated in this report as "Series of 1925"). The experiment was enlarged in 1927 by the addition of 18 plots on a better type of soil (designated as "Series of 1927"). These two series are discussed separately before summarizing all results.

Series of 1925. ${ }^{1}$ After the destructive hailstorm of August 1, 1929, the tobacco on the ten plots was harrowed in and the entire field sowed to oats, which made a luxuriant growth before winter, some plants even heading out.

The location of these 10 one-fortieth acre plots on Field $\mathrm{V}$ was exactly the same as in previous years and they received the same fertilizer ration in 1930, applied on May 22. ${ }^{2}$ Plants were set on May 27.

After the heavy leaching rains of June 8 to 10 , growth of the plants was somewhat checked, in a way which made us believe that the nitrogen had been leached out. This was also confirmed by results on the lysimeter. Therefore, on June 19, a side dressing was applied and worked in, consisting of 100 pounds nitrate of lime and 300 pounds cottonseed meal per acre.

\footnotetext{
${ }^{1}$ In previous reports designated as "Old Qualitative Potash Series."

${ }^{2}$ The composition of all fertilizer mixtures referred to in this bulletin is given in the appendix to which the reader is referred. See formulas $\mathrm{K} 1, \mathrm{~K} 5, \mathrm{~K} 7, \mathrm{~K} 8$, and $\mathrm{K} 9$.
} 
These plots are in duplicate. The five plots on one end of the field are identical in treatment with the five on the other end. As an irrigation experiment, the five plots on the east end were irrigated three times (July 19, 23 and 27), when the weather became excessively dry and hot. The west end received no water. All the tobacco (except border rows) was harvested on July 30 and sorted in December.

The only noticeable differences between the plots during the summer were the better growth on the east (irrigated) end and the

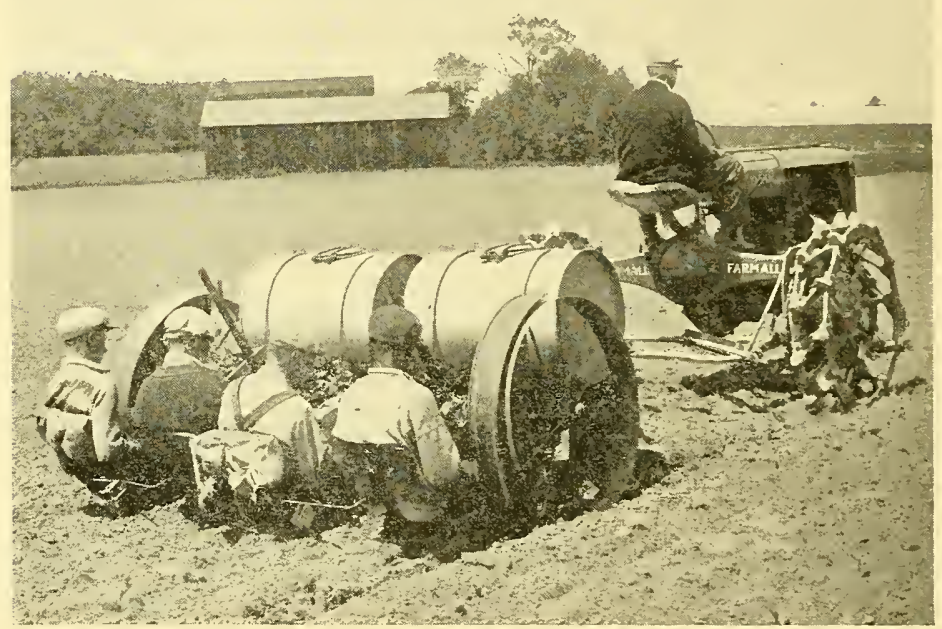

Figure 18. Two-row setter, drawn by tractor on Station farm. All operations on the farm are by tractor.

poor growth on plots K1-2 and K5 which, as mentioned in previous reports, were located in a corner apparently unfavorable for good growth.

The sorting records of 1930 are presented in Table 2 and the results for five years are summarized in Table 3. These show a slight advantage in favor of the triple source of potash. However, when it is recalled that the poor plots $\mathrm{K} 1-2$ and $\mathrm{K} 5$ on the west end make this row of questionable value and we compare only the plots on the east end with each other (Table 4), it will be seen that the differences both in yield and grade index are quite small, not sufficiently large to be of significance. 
The results indicate that as far as yield and grading are concerned it makes little difference which carrier or combination of carriers is used.

Table 2. Conparison of Sulfate, Carbonate and Nitrate of Potash. Acre Yietd and Grading of Crop of 1930. Series of 1925

\begin{tabular}{|c|c|c|c|c|c|c|c|c|c|c|c|}
\hline $\begin{array}{c}\text { Carrier } \\
\text { of potash }\end{array}$ & $\begin{array}{l}\text { Plot } \\
\text { No. }\end{array}$ & $\begin{array}{l}\text { Acre } \\
\text { yield }\end{array}$ & L & M & $\begin{array}{l}\text { Perce } \\
\text { LS }\end{array}$ & $\begin{array}{l}\text { atagc } \\
\text { SS }\end{array}$ & $\stackrel{o f}{\mathrm{LD}} 8$ & $\begin{array}{l}\text { rade: } \\
\text { DS }\end{array}$ & & $\dot{B}$ & $\begin{array}{l}\text { Grade } \\
\text { index }{ }^{1}\end{array}$ \\
\hline Sulfate & $\begin{array}{l}\text { K1-2 } \\
\text { K1-3 }\end{array}$ & $\begin{array}{l}1160 \\
1431\end{array}$ & $\begin{array}{l}3 \\
7\end{array}$ & $\begin{array}{l}10 \\
12\end{array}$ & $\begin{array}{r}9 \\
14\end{array}$ & $\begin{array}{r}14 \\
9\end{array}$ & $\begin{array}{l}28 \\
39\end{array}$ & $\begin{array}{r}21 \\
6\end{array}$ & $\begin{array}{l}15 \\
12\end{array}$ & $\begin{array}{l}0 \\
1\end{array}$ & \\
\hline Carbonate & $\begin{array}{l}\text { K5 } \\
\text { K5-1 }\end{array}$ & $\begin{array}{l}1194 \\
1389\end{array}$ & $\frac{2}{7}$ & $\begin{array}{r}3 \\
10\end{array}$ & $\begin{array}{l}14 \\
19\end{array}$ & $\begin{array}{r}10 \\
9\end{array}$ & $\begin{array}{l}32 \\
35\end{array}$ & $\begin{array}{r}18 \\
7\end{array}$ & $\begin{array}{l}18 \\
13\end{array}$ & $\begin{array}{l}3 \\
0\end{array}$ & \\
\hline $\begin{array}{l}2 / 3 \text { nitrate } \\
1 / 3 \text { carbonate }\end{array}$ & $\begin{array}{l}\text { K7 } \\
\text { K7-1 }\end{array}$ & $\begin{array}{l}1230 \\
1398\end{array}$ & $\begin{array}{r}1 \\
10\end{array}$ & $\begin{array}{r}3 \\
13\end{array}$ & $\begin{array}{l}21 \\
20\end{array}$ & $\begin{array}{r}12 \\
9\end{array}$ & $\begin{array}{l}31 \\
31\end{array}$ & $\begin{array}{r}15 \\
4\end{array}$ & $\begin{array}{l}14 \\
12\end{array}$ & 1 & \\
\hline $\begin{array}{l}1 / 2 \text { carbonate } \\
1 / 2 \text { sulfate }\end{array}$ & $\begin{array}{l}\mathrm{K} 8 \\
\mathrm{~K} 8-1\end{array}$ & $\begin{array}{l}1305 \\
1431\end{array}$ & $\begin{array}{r}2 \\
10\end{array}$ & $\begin{array}{r}6 \\
11\end{array}$ & $\begin{array}{l}21 \\
18\end{array}$ & $\begin{array}{r}11 \\
9\end{array}$ & $\begin{array}{l}34 \\
35\end{array}$ & $\begin{array}{r}12 \\
5\end{array}$ & $\begin{array}{l}12 \\
12\end{array}$ & $\begin{array}{l}2 \\
0\end{array}$ & \\
\hline $\begin{array}{l}1 / 3 \text { carbonate } \\
1 / 3 \text { sulfate } \\
1 / 3 \text { nitrate }\end{array}$ & $\begin{array}{l}\text { K9 } \\
\text { K9-1 }\end{array}$ & $\begin{array}{l}1470 \\
1422\end{array}$ & $\begin{array}{r}9 \\
11\end{array}$ & $\begin{array}{l}13 \\
10\end{array}$ & $\begin{array}{l}16 \\
20\end{array}$ & $\begin{array}{r}10 \\
9\end{array}$ & $\begin{array}{l}32 \\
30\end{array}$ & $\begin{array}{l}9 \\
7\end{array}$ & $\begin{array}{l}10 \\
12\end{array}$ & 1 & \\
\hline
\end{tabular}

${ }^{1}$ In comparing the quality of tobacco grown on different plots it is very difficult to keep in mind the percentage of eight commercial grades of tobacco from one plot and compare it with a like number from another. To simplify these comparisons a grade index is used. The grade index is a single number expressing the grading of all the tobacco grown on a particular plot. It is based on the percentage of carefully assorted commercial grades and the relative price value of the different grades. Although market prices vary from year to year, the ratios of prices between the different grades are fairly constant. These adopted price relationships for the different grades are as follows:

(L) Light wrappers ......\$1.00

(M) Medium wrappers .... .60

(LS) Long sec. (19" up) … .60

(SS) Short seconds (15" and $\left.17^{\prime \prime}\right) \ldots \ldots \ldots \ldots \ldots . .30$

The grade index of any plot is obtained by multiplying the percentage of each grade by the price in the above schedule, adding the products and dividing by 100 .
(LD) Long darks (19" up) .. \$.30

(DS) Dark stemming $\left(17^{\prime \prime}\right) \ldots \quad .20$

(F) Fillers ............ .10

(Br) Brokes ............ .10 


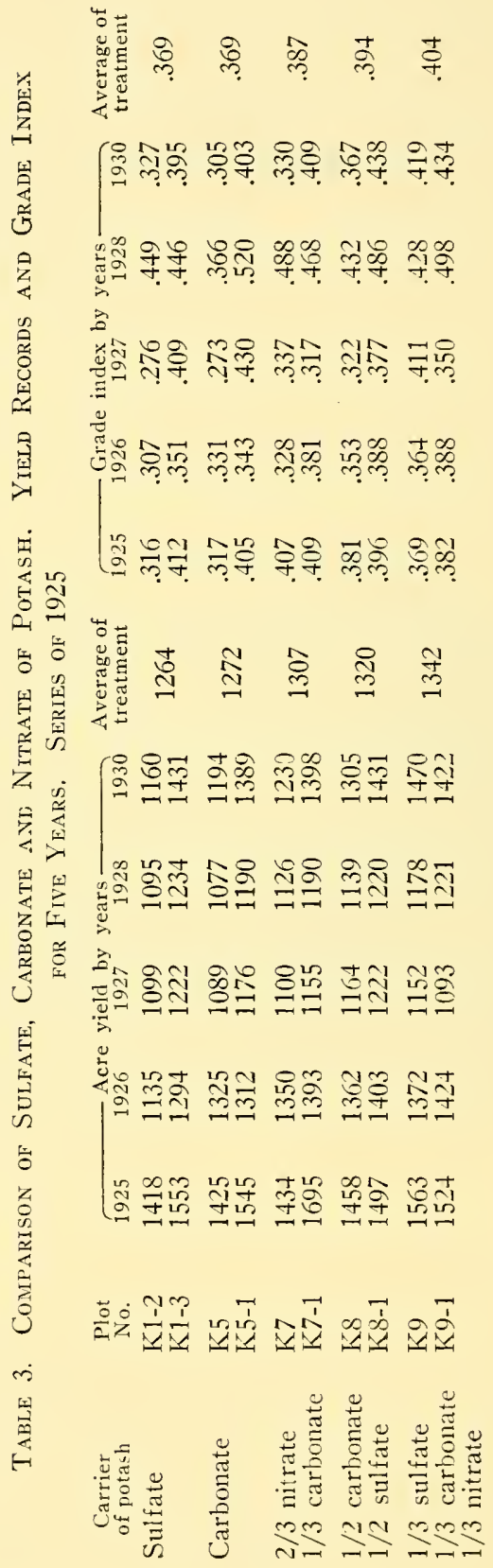


Table 4. Comparison of Sulfate, Carbonate and Nitrate of Potash Average Yields and Grade Index for Five Plots on East End for Five Years. Series of 1925

\begin{tabular}{|c|c|c|}
\hline Carrier & $\begin{array}{c}\text { Average } \\
\text { yield for } 5 \text { years }\end{array}$ & $\begin{array}{l}\text { Average grade } \\
\text { index for } 5 \text { years }\end{array}$ \\
\hline 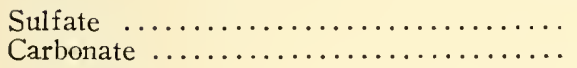 & $\begin{array}{l}1347 \\
1323\end{array}$ & $\begin{array}{l}.403 \\
.420\end{array}$ \\
\hline $\begin{array}{l}2 / 3 \text { nitrate } \ldots \ldots \ldots \ldots \ldots \ldots \ldots \ldots \ldots \ldots \ldots \ldots \ldots \\
1 / 3 \text { carbonate } \ldots \ldots \ldots \ldots \ldots \ldots\end{array}$ & 1366 & .397 \\
\hline $\begin{array}{l}1 / 2 \text { carbonate } \ldots \ldots \ldots \ldots \ldots \ldots \ldots \ldots \ldots \ldots \ldots \ldots \\
1 / 2 \text { sulfate } \ldots \ldots \ldots \ldots \ldots \ldots\end{array}$ & 1355 & $.417^{\circ}$ \\
\hline 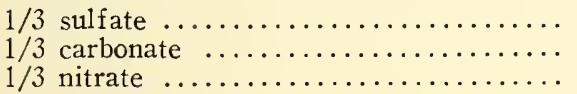 & 1337 & .410 \\
\hline
\end{tabular}

Series of $1927^{1}$. This series of 18 one-fortieth acre plots is a replication in triplicate of the 1925 series, but is on Field I, where the soil is naturally more favorable for the production of larger tobacco. The fertilizer treatment was the same as for the 1925 series except for the addition of 400 pounds per acre of hydrated lime containing 29 per cent of $\mathrm{MgO}$. The lime was added because this field was somewhat too acid and because the color of the ash needed improvement.

The fertilizer was applied on May 22 and the plants were set on June 2. No second application of fertilizer was made on this field because the soil is not so "leachy" as Field V. It did not suffer so much from the dry, hot weather, but was irrigated once during the latter part of July. All the plots were harvested on August 5 and 6 , one row only (center row of about 50 plants) being kept for the records. Growth was uniformly good on these plots and the yield heavy, being about the same as for 1923, 1925, and 1926 on this field. When sorted, there was found to be no pole sweat and very little yellow color but considerable white vein on most of the plots of this field.

The yield and sorting records, presented in Table 5, do not show very large differences either in the yields or grade indexes for the different treatments when the replicates are averaged.

\footnotetext{
${ }^{1}$ In previous reports designated as "New Qualitative Potash Series."
} 
Table 5. Comparison of Sulfate, Carbonate and Nitrate of Potash. Acre Yield and Grading of Crop of 1930. Series of 1927

\begin{tabular}{|c|c|c|c|c|c|c|c|c|c|c|c|c|c|}
\hline $\begin{array}{l}\text { Source of } \\
\text { potash }\end{array}$ & $\begin{array}{l}\text { Plot } \\
\text { No. }\end{array}$ & Plot A A & Aield- & $\mathrm{L}$ & $\mathrm{MI}$ & $\begin{array}{l}\text { erces } \\
\text { LS }\end{array}$ & $\begin{array}{l}\text { tage } \\
\text { SS }\end{array}$ & $\begin{array}{l}\text { of } g \\
L D\end{array}$ & de & F & $\mathrm{B}$ & $\begin{array}{c}\text { Grad } \\
\text { Plot }\end{array}$ & $\begin{array}{l}\text { index } \\
\text { Average }\end{array}$ \\
\hline & K1-4 & 1846 & & 21 & 7 & 14 & 5 & 40 & 2 & 11 & 0 & .486 & \\
\hline & $\mathrm{K} 1-5$ & 1884 & & 14 & 10 & 17 & 4 & 43 & 2 & 10 & 0 & .457 & \\
\hline fate & K1-6 & 1884 & 1910 & 11 & 8 & 21 & 3 & 46 & 1 & 9 & 1 & .443 & .455 \\
\hline & $\mathrm{K} 1-7$ & 2025 & & 9 & 4 & 22 & 4 & 47 & 1 & 13 & 0 & .414 & \\
\hline & K $1-9$ & & & 14 & 10 & 22 & 2 & 42 & 0 & 9 & 1 & .474 & \\
\hline & K5-2 & 1826 & & 16 & 7 & 16 & 5 & 44 & 2 & 10 & 0 & .459 & \\
\hline rbonate & K5-3 & 1838 & 1884 & 19 & 7 & 18 & 3 & 43 & 0 & 10 & 0 & .488 & .471 \\
\hline & K5-4 & 1988 & & 12 & 10 & 23 & 4 & 43 & 0 & 8 & 0 & .467 & \\
\hline rate & K7-2 & 1900 & & 22 & 8 & 17 & 4 & 37 & 1 & 11 & 0 & .506 & \\
\hline 3 carbonate & K $7-3$ & 1983 & & 13 & 3 & 25 & 2 & 44 & 1 & 10 & 2 & .450 & .464 \\
\hline & K $7-4$ & 2114 & (?) & 10 & 4 & 25 & 3 & 48 & 0 & 8 & 2 & 437 & \\
\hline 2 carbonate & K8-2 & 1862 & & 15 & 8 & 27 & 1 & 40 & 1 & 8 & 0 & .493 & \\
\hline 2 sulfate & K8-3 & $2010\}$ & & 14 & 3 & 21 & 3 & 48 & 1 & 9 & 1 & .449 & .458 \\
\hline & K8-4 & 2028 & (2) & 8 & 9 & 23 & 5 & 43 & 2 & 10 & 0 & .432 & \\
\hline & K9-2 & 1762 & & 15 & 6 & 23 & 4 & 41 & 2 & 9 & 0 & 472 & \\
\hline & K9-3 & 1984 & 1897 & 8 & 6 & 25 & 3 & 49 & 0 & 9 & 0 & .431 & .458 \\
\hline $3 \mathrm{ni}$ & K9-4 & 1944 & & 13 & 6 & 28 & 3 & 39 & 9 & 2 & 0 & .471 & \\
\hline
\end{tabular}

Records of three years on this series of plots are presented in Table 6. The only differences that may possibly be considered sufficiently large to be significant are the lower average yield and higher grade index on the carbonate plots. This tendency of the carbonate treatment has been noted in previous reports on both series.

Table 6. Comparison of Sulfate, Carbonate and Nitrate of Potash. Summary of Three Years. Series of 1927

\begin{tabular}{|c|c|c|c|c|c|c|c|c|c|}
\hline $\begin{array}{c}\text { Source } \\
\text { of potash }\end{array}$ & $\begin{array}{l}\text { Plot } \\
\text { No. }\end{array}$ & $\overparen{1927}$ & $\begin{array}{l}\text { Acre yield } \\
1928\end{array}$ & $1 \widehat{1930}$ & Average & $\tau_{1927}^{\mathrm{G}}$ & $\begin{array}{l}\text { de in } \\
1928\end{array}$ & $\operatorname{lex}_{1930}$ & Average \\
\hline Sulfate & $\begin{array}{l}\mathrm{K} 1-4 \\
\mathrm{~K} 1-5 \\
\mathrm{~K} 1-6 \\
\mathrm{~K} 1-7 \\
\mathrm{~K} 1-8 \\
\mathrm{~K} 1-9\end{array}$ & $\begin{array}{l}1273 \\
1250 \\
1261 \\
1258 \\
1276 \\
1320\end{array}$ & $\begin{array}{l}1410 \\
1335 \\
1476 \\
1366 \\
1356 \\
1442\end{array}$ & $\begin{array}{l}1846 \\
1884 \\
1884 \\
2025 \\
(1910)^{1} \\
(1910)\end{array}$ & 1527 & $\begin{array}{l}.394 \\
.389 \\
.372 \\
.413 \\
.345 \\
.380\end{array}$ & $\begin{array}{l}.455 \\
.405 \\
.425 \\
.408 \\
.511 \\
.420\end{array}$ & $\begin{array}{l}.486 \\
.457 \\
.443 \\
.414 \\
(.455) \\
.474\end{array}$ & .425 \\
\hline Carbonate & $\begin{array}{l}\text { K5-2 } \\
\text { K5-3 } \\
\text { K5-4 }\end{array}$ & $\begin{array}{l}1230 \\
1246 \\
1307\end{array}$ & $\begin{array}{l}1320 \\
1261 \\
1419\end{array}$ & $\begin{array}{l}1826 \\
1838 \\
1988\end{array}$ & 1493 & $\begin{array}{l}.410 \\
.394 \\
.421\end{array}$ & $\begin{array}{l}.431 \\
.481 \\
.499\end{array}$ & $\begin{array}{l}.459 \\
.488 \\
.467\end{array}$ & .450 \\
\hline $\begin{array}{l}2 / 3 \text { nitrate } \\
1 / 3 \text { carbonate }\end{array}$ & $\begin{array}{l}\mathrm{K} 7-2 \\
\mathrm{~K} 7-3 \\
\mathrm{~K} 7-4\end{array}$ & $\begin{array}{l}1271 \\
1250 \\
1318\end{array}$ & $\begin{array}{l}1394 \\
1330 \\
1416\end{array}$ & $\begin{array}{l}1900 \\
1983 \\
(1941)\end{array}$ & 1534 & $\begin{array}{l}.419 \\
.380 \\
.326\end{array}$ & $\begin{array}{l}.416 \\
.507 \\
.392\end{array}$ & $\begin{array}{l}.506 \\
.450 \\
.437\end{array}$ & .426 \\
\hline $\begin{array}{l}1 / 2 \text { sulfate } \\
1 / 2 \text { carbonate }\end{array}$ & $\begin{array}{l}\text { K8-2 } \\
\text { K8-3 } \\
\text { K8-4 }\end{array}$ & $\begin{array}{l}1319 \\
1280 \\
1345\end{array}$ & $\begin{array}{l}1331 \\
1391 \\
1445\end{array}$ & $\begin{array}{c}1862 \\
2010 \\
(1936)\end{array}$ & 1546 & $\begin{array}{l}.396 \\
.369 \\
.463\end{array}$ & $\begin{array}{l}.416 \\
.389 \\
.458\end{array}$ & $\begin{array}{l}.493 \\
.449 \\
.432\end{array}$ & .429 \\
\hline $\begin{array}{l}1 / 3 \text { carbonate } \\
1 / 3 \text { nitrate } \\
1 / 3 \text { sulfate }\end{array}$ & $\begin{array}{l}\mathrm{K} 9-2 \\
\mathrm{~K} 9-3 \\
\mathrm{~K} 9-4\end{array}$ & $\begin{array}{l}1292 \\
1319 \\
1284\end{array}$ & $\begin{array}{l}1394 \\
1353 \\
1495\end{array}$ & $\begin{array}{l}1762 \\
1984 \\
1944\end{array}$ & 1536 & $\begin{array}{l}.414 \\
.365 \\
.403\end{array}$ & $\begin{array}{l}.385 \\
.441 \\
.452\end{array}$ & $\begin{array}{l}.472 \\
.431 \\
.471\end{array}$ & .426 \\
\hline
\end{tabular}

${ }^{1}$ Figures in parenthesis represent averages of other plots of the same treatment and year, and are substituted where the real records were accidentally lost or confused. 


\section{Summary and Discussion}

Aside from these small but persistent differences in the carbonate plots, it would seem, from all results up to date on both series, that it makes little difference which of the three or which combination of the three carriers is used to supply the potash requirements of a tobacco crop. The yield per acre and the grading of the crop are essentially the same.

This result is not surprising in view of the known behavior of potash salts when incorporated with soil. As soon as any one of these potash compounds goes into solution in the soil, the potassium cation unites with the large acetoid or colloidal exchange anion, displacing hydrogen, calcium or magnesium, or possibly other cations which in turn unite with sulfate or nitrate or carbonate of the added fertilizer salt. Thus the potash compound, which is more or less stable in the soil and from which the tobacco roots must obtain the plant's ration of potash, is just the same, regardless of the carrier in which potash was furnished in the fertilizer, and it would be anticipated that the results on the crop would be similar. When sulfate of potash is used, a difference in growth or quality due to increase in amount of sulfate in the soil solution might be anticipated, but such a difference is minimized by the limited capacity of the tobacco plant to accumulate or increase its sulfur content (see Report of the Tobacco Substation for 1929, page 213). In the formula where nitrate of potash is used, there is no increase in the total nitrate added because the nitrate of soda in the mixture is correspondingly reduced when nitrate of potash is added. When carbonate is used, it is decomposed or changed to a bicarbonate and if this anion is taken into the plant it could hardly produce a marked difference in a medium where carbonic acid from the air is ever present in sufficient quantity.

\section{Ground Tobacco Stems as a Source of Potash}

The three plots on which tobacco stems are used as the only source of potash are located on Field I, between the other Sourceof-Potash plots. The fertilizer mixture used was essentially the same as in preceding years, composed as follows:

\section{2,650 lbs. ground tobacco stems \\ 1,529 lbs. cottonseed meal \\ 260 lbs. nitrate of soda}

This formula furnishes 200 pounds of nitrogen and a like amount of potash. For the 1930 experiment, ground sterilized stems were substituted for the long stems used in the experiments of previous years. The stems were mixed with the other fertilizer ingredients and spread in a single application. Ground stems, which are a by-product of the extraction of nicotine sulfate (an 
insecticide), have certain advantages over long stems: (1) Being sterilized by steaming in the process of nicotine extraction, they are free from danger of carrying such diseases as wildfire and mosaic to the young plants. (2) The moisture content is low and constant. (3) Their mechanical condition makes them easy to mix with the other fertilizer ingredients and also makes the plant food more quickly available.

Dates of setting and harvesting were the same as for the adjacent plots.

Table 7. Stems Plots. Acre Yield and Grading as Compared with Other Sources of Potash. Crop of 1930

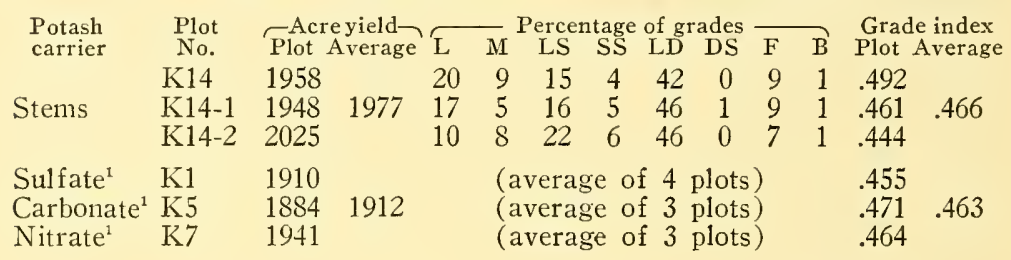

The yield and sorting records (Table 7 ) indicate that stems are a sufficient source of potash and a good one, since the yield was somewhat higher than that of plots where other potash carriers were used, and the grade index was about the same.

Stems are a desirable fertilizer material because, being a residue of the tobacco plant, it is safe to assume that they contain, besides potash, a supply of all other elements that are needed by the growing tobacco plants. In order to see whether this assumption is warranted, a pot experiment on very poor, worn-out soil was tried in the greenhouse. A heavy application of stems was used as the only fertilizer, on six out of 12 pots. No stems or other fertilizer were applied to the other six. Young tobacco plants in the untreated pots made practically no growth, while those in the stems pots grew rapidly and luxuriantly. One plant of each series is shown in Figure 19. Only in the last stages of growth did the plants grown on stems show some symptoms of shortage of nitrogen.

\section{Chemical Analysis of Tobacco on Stems Plots}

In order to see how much potash the crop actually absorbs from stems, as compared with other potash carriers, samples of the fermented crop of 1928 were analyzed.2 ${ }^{2}$ Since it was possible that

\footnotetext{
${ }^{1}$ Averages from Table 5.

${ }^{2}$ The analyses were made by the Department of Analytical Chemistry, at New Haven.
} 
the other bases in the leaf might be affected, a determination of the percentage of $\mathrm{CaO}$ and $\mathrm{MgO}$ was also made. Results of the analyses are presented in Table 8 .

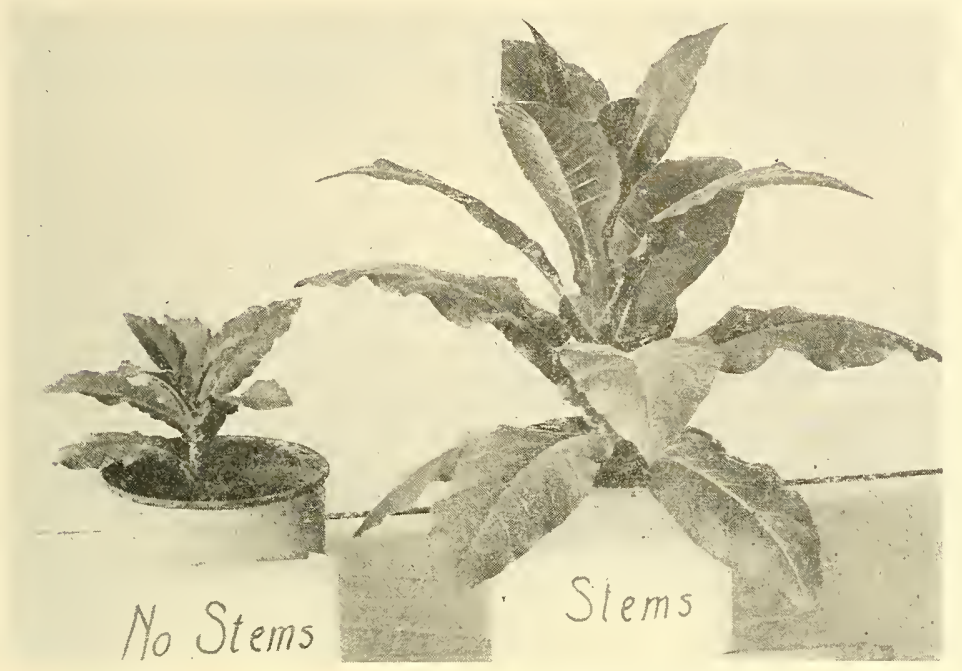

Figure 19. Plant on right received tobacco stems only as a fertilizer. Plant on left had no fertilizer.

Table 8. Analyses of Tobacco from Stems Plots ${ }^{2}$

\begin{tabular}{|c|c|c|c|c|c|c|c|c|}
\hline \multirow{2}{*}{$\begin{array}{c}\text { Source of } \\
\text { potash in fertilizer }\end{array}$} & \multirow{3}{*}{$\begin{array}{l}\text { Plot } \\
\text { No. } \\
\text { K14 } \\
\text { K14 } \\
\text { K14-1 } \\
\text { K14-1 }\end{array}$} & \multirow{3}{*}{$\begin{array}{c}\text { Grade } \\
\text { D } \\
\text { S } \\
\text { D } \\
\text { S }\end{array}$} & \multicolumn{2}{|c|}{$\approx \mathrm{K}_{2} \mathrm{O}-$} & & intage of & \\
\hline & & & $\overparen{\text { Plot }}$ & Average & Plot & Average & Plot & Average \\
\hline $\begin{array}{l}\text { Stems to supply } 200 \\
\text { lbs. } \mathrm{K}_{2} \mathrm{O} \ldots \ldots \ldots .\end{array}$ & & & $\begin{array}{l}7.42 \\
9.72 \\
7.79 \\
9.14\end{array}$ & 8.52 & $\begin{array}{l}8.57 \\
5.50 \\
5.83 \\
6.22\end{array}$ & 6.53 & $\begin{array}{l}.88 \\
.77 \\
.73 \\
.68\end{array}$ & .77 \\
\hline $\begin{array}{l}200 \mathrm{lbs} . \mathrm{K}_{2} \mathrm{O} \text { in nitrate, } \\
\text { sulfate and carbonate }\end{array}$ & $\begin{array}{l}\text { K9-5 } \\
\text { K9-5 }\end{array}$ & $\mathrm{D}$ & $\begin{array}{l}7.30 \\
8.64\end{array}$ & 7.97 & $\begin{array}{l}5.97 \\
6.52\end{array}$ & 6.25 & $\begin{array}{l}.82 \\
.77\end{array}$ & .80 \\
\hline $\begin{array}{l}300 \text { lbs. } \mathrm{K}_{2} \mathrm{O} \text { in nitrate, } \\
\text { sulfate and carbonate } \\
\text { of potash .......... }\end{array}$ & $\begin{array}{l}\text { K13-2 } \\
\text { K13-2 } \\
\text { K13-3 } \\
\text { K13-3 }\end{array}$ & $\begin{array}{l}\mathrm{D} \\
\mathrm{S} \\
\mathrm{D} \\
\mathrm{S}\end{array}$ & $\begin{array}{l}8.54 \\
9.14 \\
8.19 \\
8.83\end{array}$ & 8.68 & $\begin{array}{l}5.57 \\
6.05 \\
5.87 \\
6.43\end{array}$ & 5.98 & $\begin{array}{l}.77 \\
.73 \\
.78 \\
.68\end{array}$ & .74 \\
\hline
\end{tabular}

Thus when 200 pounds of $\mathrm{K}_{2} \mathrm{O}$ per acre were supplied in stems, the crop absorbed at least as much as when the same amount of potash was supplied from mineral carriers. The percentage in the crop was almost as large as when 300 pounds of potash was supplied in mineral carriers.

${ }^{1}$ Figures are on air-dry basis; water content, about seven per cent. 
In this connection, it is of interest to note that in the Poquonock experiments of 1892-96, Dr. Jenkins (Connecticut Agricultural Experiment Station Report for 1896, page 331) found the highest percentage of potash (nine per cent) in the tobacco on the plot that had been fertilized with stems. However, in these earlier experiments the stems applied to this plot contained more potash (486 pounds per acre) than the fertilizers applied to the other plots (340 pounds per acre).

\section{Cotton Hull Ashes as a Source of Potash}

Thirty to forty years ago, ash resulting from the burning of cotton seed hulls in the South was a commonly used source of potash for tobacco in New England. This ash contained a variable percentage (15 to 35 per cent) of potash in the form of carbonate, carbonates of calcium and magnesium, and some phosphoric acid (average about nine per cent), as well as small amounts of other elements, some of which may be of importance in plant growth. ${ }^{1}$ According to analyses made during the last year on 14 samples (Table 9), the chlorine content varies from .43 to 2.33 per cent. This is probably not sufficient to affect the burn seriously.

${ }^{1}$ The Station Report for 1897, page 144, gives the average analyses of 195 samples of cotton hull ashes as follows:

\begin{tabular}{|c|c|c|c|}
\hline & $\begin{array}{c}\text { Ash of } \\
\text { pure hulls }\end{array}$ & $\begin{array}{l}\text { Commercial } \\
\text { cotton } \\
\text { hull ash }\end{array}$ & $\begin{array}{c}\text { Average } \\
\text { composition } \\
\text { (185 analyses) }\end{array}$ \\
\hline 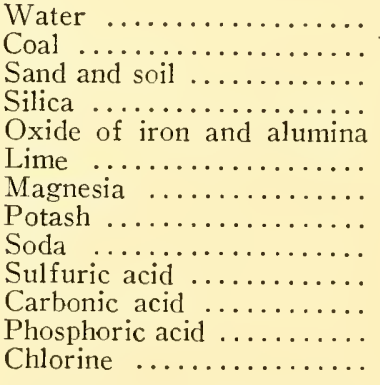 & $\begin{array}{r}7.56 \\
1.21 \\
1.69 \\
5.29 \\
11.29 \\
42.13 \\
3.35 \\
3.04 \\
20.10 \\
2.96 \\
1.74\end{array}$ & $\begin{array}{r}5.95 \\
1.86 \\
6.16 \\
1.00 \\
.54 \\
15.68 \\
3.47 \\
36.76 \\
1.18 \\
1.92 \\
22.22 \\
3.10 \\
1.40\end{array}$ & $\begin{array}{r}2.07 \\
8.85 \\
9.97 \\
23.40 \\
2.58 \\
2.56\end{array}$ \\
\hline \multirow[t]{2}{*}{$\begin{array}{l}\text { Deduct oxygen equivalent to } \\
\text { chlorine } \ldots . . . \ldots \ldots \ldots . .\end{array}$} & 100.36 & 101.24 & \\
\hline & 100.00 & 100.92 & \\
\hline
\end{tabular}


Table 9. Chemical Analyses of Siamples of Cotton Hull Ashes Sold FOR TOBACCO IN $1930^{1}$

$\begin{array}{cccccccc}\begin{array}{c}\text { Lab. } \\ \begin{array}{c}\text { No. of } \\ \text { sample }\end{array}\end{array} & \begin{array}{c}\mathrm{K}_{2} \mathrm{O} \\ \%\end{array} & \begin{array}{c}\mathrm{P}_{2} \mathrm{O}_{5} \\ \%\end{array} & \begin{array}{c}\mathrm{CaO} \\ \%\end{array} & \begin{array}{c}\mathrm{MgO} \\ \%\end{array} & \begin{array}{c}\mathrm{Cl} \\ \%\end{array} & \begin{array}{c}\text { Boron }\left(\mathrm{B}_{2} \mathrm{O}_{3}\right) \\ \%\end{array} & \text { Water } \\ 3601 & 31.67 & 2.15 & 10.67 & 4.35 & 2.33 & 0.029 & \\ 3667 & 23.35 & 2.90 & 12.52 & 4.38 & 1.34 & 0.024 & \\ 3668 & 24.60 & 2.80 & 11.41 & 5.17 & 1.45 & 0.022 & \\ 3669 & 24.79 & 2.78 & 11.47 & 4.99 & 1.47 & 0.035 & \\ 3693 & 22.95 & 3.07 & 10.38 & 5.05 & 1.39 & 0.022 & \\ 3694 & 23.64 & 2.86 & 10.15 & 4.48 & 1.59 & 0.024 & \\ 3753 & 25.27 & 3.71 & 8.33 & 3.93 & 0.94 & 0.021 & \\ 3786 & 29.97 & 2.72 & 8.50 & 3.97 & 1.97 & 0.029 & \\ 3818 & 29.07 & 2.65 & 9.16 & 3.93 & 2.15 & 0.036 & \\ 3826 & 23.03 & 2.33 & 15.35 & 5.64 & 0.87 & 0.008 & \\ 3827 & 33.57 & 1.88 & 12.62 & 3.94 & 1.84 & 0.011 & \\ 3949 & 20.97 & 3.18 & 19.94 & 8.14 & 0.43 & 0.011 & \\ 3990 & 38.17 & 2.80 & 14.10 & 4.93 & 1.76 & 0.003 & \\ 4026 & 25.31 & 5.00 & 12.73 & 5.35 & 0.83 & 0.009 & \\ \text { Average } & 26.88 & 2.92 & 11.95 & 4.87 & 1.45 & 0.020 & \text { App. 9.00-10.00 }\end{array}$

Later, the use of cotton hull ashes was discontinued, but within the last five years this material has again appeared on the market and has been used with success by many growers.

In order to compare it with other sources of potash, five plots were added in 1929 to those described above as the Source-ofPotash plots on Field I. The formula used was as follows:

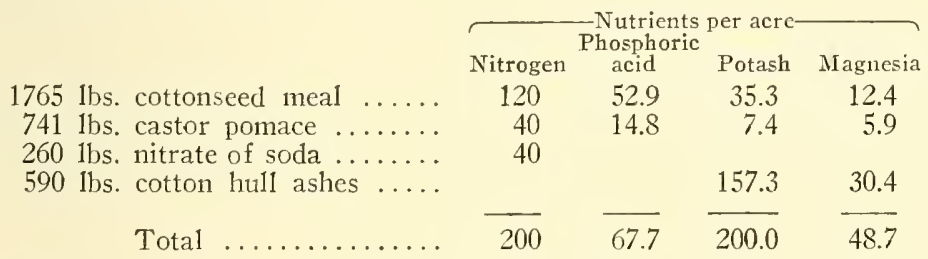

This supplied the same quantity of the elements as was applied to the adjacent plots. No results were computed in 1929 because the tobacco was destroyed by hail and the experiment was repeated in 1930 on the same plots. The records on yield and grading given in Table 10 show a lower yield on all cotton hull ash plots as compared with the average of any of the other sources of potash. The grade index on two of the plots was about the same as for the other sources of potash. On the other plots it was lower.

The results do not indicate that cotton hull ashes are a more favorable source of potash than the other carriers. Since the form in which the potash occurs here is mostly carbonate of potash, it is probable that any more favorable results that might be

\footnotetext{
${ }^{1}$ Analyses by the Department of Analytical Chemistry. Published by courtesy of Dr. E. M. Bailey.
} 
Table 10. Cotton Hull Ashes Compared with Other Sources of Potash. ACre Yield and Grading. Crop of 1930

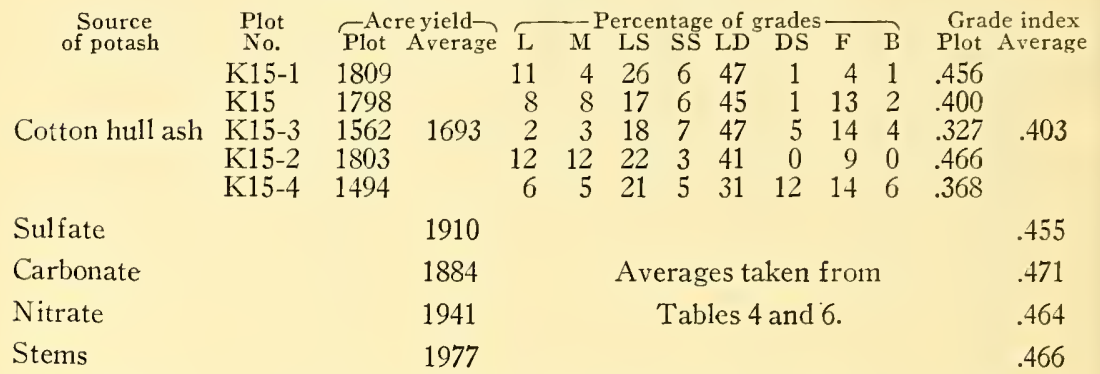

expected would come from the other elements in the ash. In view of our results with magnesia; reported in another section of this bulletin, it seems likely that the quantity of this element in cotton hull ashes would have a favorable effect on the burn.

Through the courtesy of one of the large cigar manufacturing corporations, the writers tested the smoking quality of cigars from tobacco raised on a cotton hull ash formula contrasted with an equal number of others raised on the same 12 fields in various parts of the Connecticut Valley, but with other sources of potash (standard commercial fertilizer mixtures). Neither the writers nor the experts from the manufacturing company could detect any consistently favorable influence on the burn, taste or aroma of the cotton hull ash cigars as compared with the others.

Final conclusions as to the relative value of cotton hull ashes and other potash carriers must await the continuation of these experiments through a series of years. Nothing in the results at present indicates that this material is in any way superior to some of the others.

\section{Quantity of Potash}

In order to determine the optimum quantity of potash to apply in the fertilizer, a series of six one-fortieth acre plots was started on Field V in 1926 (Series of $1926^{1}$ ). In 1927 this experiment was enlarged by addition of 15 plots on Field I (Series of $1927^{2}$ ). These two series are discussed separately below.

Series of 1926 . These six plots received the same fertilizer treatment in 1930 as in the preceding four years. ${ }^{3}$

The fact that the crop of 1929 was harrowed into the soil and a cover crop of oats sowed early in August undoubtedly had an effect on the results in 1930. Omission of all special carriers of potash in 1930 did not have as serious effect in reducing yield and quality

'In previous reports designated as "Old Quantitative Series."

"In previous reports designated as "New Quantitative Series."

${ }^{3}$ See Appendix for formulas for plots $\mathrm{K} 9, \mathrm{~K} 11$, and $\mathrm{K} 12$. 
of the tobacco as might have been anticipated. The supply of available potash had been built up because none of it had been removed in the crop of the previous year. The tobacco plants in 1929 on the "no-potash" plots not only utilized the small amount that was present in the "organics" of the fertilizer; they also were able to secure an additional supply from the natural but less available soil potash compounds. This combined supply was returned to the soil in a perfectly available form and was next absorbed by the oats crop. This crop not only utilized the available supply from the tobacco, but also added some of the natural soil potash. When the oats crop was plowed under in the spring most of its potash was probably in a form available to the 1930 tobacco crop.

Fertilizer was applied to these plots on May 22 and the plants were set on May 27. On June 19 a side dressing of 100 pounds nitrate of lime and 300 pounds cottonseed meal per acre were applied. All the plots except K9 were irrigated on July 19 and July 25. They were harvested July 31 (three rows of each plot) and sorted in December. Differences in growth as observed in the field were not so marked as they were in 1928, probably for reasons previously discussed. Sorting records presented in Table 11 show

Table 11. Quantity of Potash. Acre Yield and Grading of Crop of 1930. SERIES OF 1926

\begin{tabular}{|c|c|c|c|c|c|c|c|c|c|c|c|c|c|}
\hline $\begin{array}{l}\text { Lbs. potash } \\
\text { per acre }\end{array}$ & $\begin{array}{l}\text { Plot } \\
\text { No. }\end{array}$ & \multicolumn{3}{|c|}{-Acre vield } & M & \multicolumn{4}{|c|}{$\begin{array}{l}\text { Percentage of grades } \\
\text { LS SS LD DS }\end{array}$} & $\mathrm{F}$ & B & \multicolumn{2}{|c|}{$\begin{array}{l}\text { Grade index } \\
\text { Plot Average }\end{array}$} \\
\hline & $\mathrm{K} 11$ & 1430 & & 3 & 9 & 13 & 9 & 43 & 8 & 12 & 3 & .349 & \\
\hline None & $\mathrm{K} 11-1$ & 1306 & 1368 & 0 & 4 & 12 & 6 & 39 & 14 & 15 & 10 & .284 & .317 \\
\hline 100 & $\begin{array}{l}\text { K12 } \\
\text { K12-I }\end{array}$ & $\begin{array}{l}1541 \\
1304\end{array}$ & 1422 & $\begin{array}{l}4 \\
3\end{array}$ & $\begin{array}{l}5 \\
8\end{array}$ & $\begin{array}{l}22 \\
14\end{array}$ & $\begin{array}{l}7 \\
9\end{array}$ & $\begin{array}{l}39 \\
37\end{array}$ & $\begin{array}{l}4 \\
9\end{array}$ & $\begin{array}{l}12 \\
15\end{array}$ & $\begin{array}{l}7 \\
5\end{array}$ & $\begin{array}{l}.367 \\
.338\end{array}$ & .357 \\
\hline 200 & $\begin{array}{l}\text { K9 } \\
\text { K9-1 }\end{array}$ & $\begin{array}{l}1470 \\
1422\end{array}$ & 1446 & $\begin{array}{r}9 \\
11\end{array}$ & $\begin{array}{l}13 \\
10\end{array}$ & $\begin{array}{l}16 \\
20\end{array}$ & $\begin{array}{r}10 \\
9\end{array}$ & $\begin{array}{l}32 \\
30\end{array}$ & $\begin{array}{l}9 \\
7\end{array}$ & $\begin{array}{l}10 \\
12\end{array}$ & $\begin{array}{l}1 \\
1\end{array}$ & $\begin{array}{l}.419 \\
.434\end{array}$ & .427 \\
\hline
\end{tabular}

only a small reduction in yield due to shortage of potash. This would have been more pronounced if plot $\mathrm{K} 9$ had been irrigated as were the other plots. With the shortage of potash the reduction in quality was more pronounced than the reduction in quantity, as shown by comparing the grade index of each.

Table 12. Quantity of Potash. Summary of Yields and Grading for Three Years. Series of 1926

\begin{tabular}{|c|c|c|c|c|c|c|c|c|c|}
\hline \multirow{2}{*}{$\begin{array}{l}\text { Lbs. potash } \\
\text { per acre }\end{array}$} & \multirow{2}{*}{$\begin{array}{l}\text { Plot } \\
\text { No. }\end{array}$} & \multicolumn{3}{|c|}{ Acre yields by years } & \multicolumn{4}{|c|}{ Index by years } & \multirow[b]{2}{*}{ Average } \\
\hline & & 1927 & 1928 & 1930 & Average & 1927 & 1928 & 1930 & \\
\hline None & $\begin{array}{l}\mathrm{K} 11 \\
\mathrm{~K} 11-1\end{array}$ & $\begin{array}{l}1150 \\
1137\end{array}$ & $\begin{array}{l}1107 \\
1163\end{array}$ & $\begin{array}{l}1430 \\
1306\end{array}$ & 1215 & $\begin{array}{l}.281 \\
.298\end{array}$ & $\begin{array}{l}.194 \\
.233\end{array}$ & $\begin{array}{l}.349 \\
.284\end{array}$ & 273 \\
\hline 100 & $\begin{array}{l}\text { K12 } \\
\text { Ki2-1 }\end{array}$ & $\begin{array}{l}1247 \\
1141\end{array}$ & $\begin{array}{l}1107 \\
1076\end{array}$ & $\begin{array}{l}1541 \\
1304\end{array}$ & 1236 & $\begin{array}{l}.368 \\
.364\end{array}$ & $\begin{array}{l}.321 \\
.324\end{array}$ & $\begin{array}{l}.367 \\
.338\end{array}$ & 347 \\
\hline 200 & $\begin{array}{l}\text { K9 } \\
\text { K9-1 }\end{array}$ & 1152 & $\begin{array}{l}1178 \\
1221\end{array}$ & $\begin{array}{l}1470 \\
1422\end{array}$ & 1266 & .411 & $\begin{array}{l}.428 \\
.498\end{array}$ & $\begin{array}{l}.419 \\
.434\end{array}$ & .433 \\
\hline
\end{tabular}

* No special carriers of potash were applied to any of the K11 plots but the cottonseed meal and castor pomace of the formula furnished 43 pounds $\mathrm{K}_{2} \mathrm{O}$ per acre. 
The sorting records for the three years 1927, 1928, and 1930 presented in. Table 12 show that the effects noted in 1930 are similar to those of the previous years. The notes taken at the time of sorting show as in previous years that without an adequate supply of potash, the tobacco becomes short, dry, yellow, nonelastic and lifeless. Although the leaves on these no-potash plots are much smaller than on the regular ration plots, the weight of tobacco per plot is not much less because the leaves are thick and heavy.

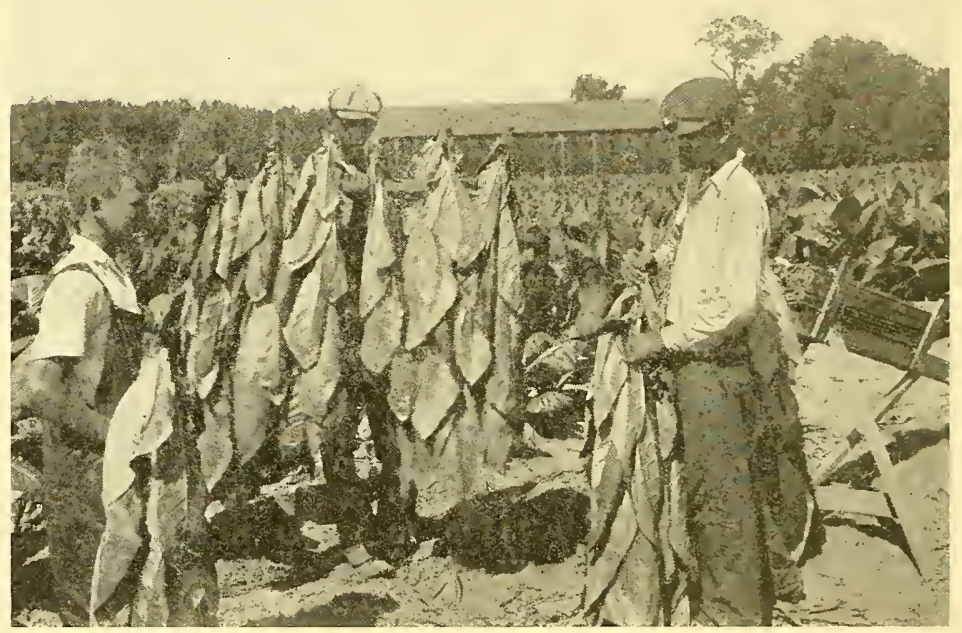

Figure 20. Spearing tobacco on the Station farm, 1930.

Series of 1927. Treatment on the replicate plots on Field I (Series of 1927) was the same as the Series of 1926 and the same notes as to treatment after the hail storm of 1929 apply here. Fertilizer was applied on May 22 and the plants set on June 2. No significant differences in growth in the field were observed except that the leaves appeared smaller on some of the no-potash plots. No side dressing of fertilizer was applied. The plots were irrigated once during the latter part of Jttly. All plots were harvested August 5 and 6.

The sorting records, presented in Table 13, lead to the same conclusion as expressed for the other series, namely, that shortage of potash affects the grading more than the yield of tobacco. 
Table 13. Quantity of Potash. Yield and Grading Records, Crop of 1930. SERIES OF 1927 ON Field I

\begin{tabular}{|c|c|c|c|c|c|c|c|c|c|c|c|c|c|}
\hline & Plot & Acr & eyield- & & & Perce & atag & of $g$ & ade & & & Gra & \\
\hline & & Plot & & $\mathrm{L}$ & M & LS & SS & LD & DS & F & B & & . \\
\hline & K11-2 & 1828 & & 8 & 6 & 24 & 4 & 46 & 2 & 10 & & .436 & \\
\hline None & & 1782 & & 3 & 4 & 16 & 5 & 49 & 4 & 19 & & .327 & \\
\hline & & 1884 & 1813 & 2 & 2 & 18 & 5 & 57 & 3 & 12 & 1 & .345 & \\
\hline & & 1758 & & 7 & 4 & 18 & 11 & 45 & 3 & 12 & & .388 & \\
\hline & & 1864 & & 13 & 8 & 19 & 6 & 43 & 2 & 9 & & 2 & \\
\hline 100 lbs. & $\mathrm{K}$ & 2080 & 1945 & 11 & 3 & 17 & 5 & 53 & 2 & 9 & & .417 & .427 \\
\hline & $\mathrm{K} 12-4$ & 1890 & & 5 & 3 & 30 & 6 & 44 & 1 & 11 & & .411 & \\
\hline & K9-5 & 1932 & & 12 & 5 & 25 & 4 & 46 & 1 & 7 & & .459 & \\
\hline $200 \mathrm{lbs}$. & K9-6 & 1890 & 1886 & 14 & 8 & 22 & 4 & 40 & 1 & 11 & & .465 & .442 \\
\hline & K9-7 & 836 & & 5 & 2 & 29 & 3 & 48 & 1 & 12 & & .403 & \\
\hline & $\mathrm{K} 13$ & 694 & & 20 & 6 & 21 & 6 & 36 & 1 & 9 & & .500 & \\
\hline $300 \mathrm{lbs}$. & & 1872 & 1834 & 9 & 4 & 29 & 5 & 45 & & 8 & & .446 & .477 \\
\hline & & 1935 & & 17 & 4 & 24 & 4 & 41 & 1 & 9 & & .484 & \\
\hline 300 lbs. $^{1}$ & K13-4 & 1755 & & 11 & 7 & 17 & 11 & 42 & & 12 & & .425 & \\
\hline $200 \mathrm{lbs}^{1}$ & K9-8 & 1682 & & 14 & 4 & 21 & 7 & 41 & 3 & 10 & & .450 & \\
\hline
\end{tabular}

\section{Effect of the Quantity of Potash Applied in the Fertilizer on the Percentage of Potash, Lime and Magnesia in the Leaf}

In previous reports it has been stated that with decreasing amounts of potash applied in the fertilizer, not only is the percentage of potash absorbed by the leaf reduced, but also there is a corresponding increase in the other mineral bases. In order to see how far these changes had gone, samples of darks and seconds of the crop of 1928 from both series were analyzed for bases after the tobacco had been fermented and aged for a year. Results of these analyses are presented in Tables 14 and 15 .

Table 14. Percentage of Potash, Lime and Magnesia in Cured Leaves. Quantitative Potash Series of 1926. Crop of 1928, THE Third on These Plots ${ }^{2}$

\begin{tabular}{|c|c|c|c|c|c|c|c|c|}
\hline \multirow{3}{*}{$\begin{array}{l}\text { Lbs. potash } \\
\text { per acre in } \\
\text { the fertilizer }\end{array}$} & \multirow{3}{*}{$\begin{array}{l}\text { Plot } \\
\text { No. }\end{array}$} & \multirow[b]{3}{*}{ Grade } & \multirow{2}{*}{\multicolumn{2}{|c|}{ Potach (Ko) }} & \multicolumn{4}{|c|}{ Per cent in } \\
\hline & & & & & er ce? & $(\mathrm{CaO})-$ & Mag. & $(\mathrm{MgO})$ \\
\hline & & & Plot & Average & Plot & Average & Plot & Average \\
\hline & K11 & D & 3.63 & & 8.12 & & .82 & \\
\hline None & K11 & S & $\begin{array}{l}3.56 \\
409\end{array}$ & 4.07 & $\begin{array}{l}8.71 \\
767\end{array}$ & 8.17 & 1.07 & .94 \\
\hline & $\begin{array}{l}\mathrm{K} 11-1 \\
\mathrm{~K} 11-1\end{array}$ & $\begin{array}{l}\mathrm{D} \\
\mathrm{S}\end{array}$ & $\begin{array}{l}4.09 \\
5.01\end{array}$ & & & & $\begin{array}{l}.90 \\
.90\end{array}$ & \\
\hline & K12 & $\mathrm{D}$ & 5.74 & & 6.61 & & .64 & \\
\hline 100 & K12 & S & 5.79 & 555 & 6.83 & 671 & .60 & .62 \\
\hline & $\begin{array}{l}\mathrm{K} 12-1 \\
\mathrm{~K} 12-1\end{array}$ & $\begin{array}{l}\mathrm{D} \\
\mathrm{S}\end{array}$ & $\begin{array}{l}5.35 \\
5.33\end{array}$ & & $\begin{array}{l}6.77 \\
6.64\end{array}$ & & $\begin{array}{l}.63 \\
.61\end{array}$ & \\
\hline & K9 & D & 6.27 & & 5.83 & & .69 & \\
\hline 200 & K9 & S & 7.01 & 660 & 5.74 & 507 & .61 & 69 \\
\hline & K9-1 & D & 6.70 & 0.09 & 5.78 & 5.08 & .74 & .09 \\
\hline & K9-1 & S & 6.76 & & 6.11 & & .70 & \\
\hline
\end{tabular}

${ }^{1}$ These two plots were on a different part of the field from the others and therefore not included in averages.

${ }^{2}$ Figures are on air-dry basis; water content, about seven per cent. 
Table 15. Percentage of Potash, Lime and Magnesia in Cured Leaves. Quantitative Potash Series of 1927, Crop of 1928,

the Second on These Plots

\begin{tabular}{|c|c|c|c|c|c|c|c|c|}
\hline \multirow{3}{*}{$\begin{array}{l}\text { Lbs. potash } \\
\text { per acre in } \\
\text { the fertilizer }\end{array}$} & \multirow{4}{*}{$\begin{array}{c}\text { Plot } \\
\text { No. } \\
\text { K11-2 } \\
\text { K11-2 }\end{array}$} & \multirow{4}{*}{$\begin{array}{c}\text { Grade } \\
\text { D } \\
\text { S }\end{array}$} & \multirow{3}{*}{\multicolumn{2}{|c|}{ Potash $\left(\mathrm{K}_{2} \mathrm{O}\right)$}} & \multicolumn{4}{|c|}{ Porcont in the lonf } \\
\hline & & & & & & $\begin{array}{l}\text { in the leaf } \\
(\mathrm{CaO})\end{array}$ & $\mathrm{Mag}$ & $(\mathrm{MgO})$ \\
\hline & & & & & Plot & & Plot & Áverage \\
\hline None & & & $\begin{array}{l}6.03 \\
5.87\end{array}$ & 5.95 & $\begin{array}{l}7.19 \\
7.93\end{array}$ & 7.56 & $\begin{array}{l}.96 \\
.90\end{array}$ & .93 \\
\hline 100 & $\begin{array}{l}\mathrm{K} 12-2 \\
\mathrm{~K} 12-2\end{array}$ & $\begin{array}{l}\mathrm{D} \\
\mathrm{S}\end{array}$ & $\begin{array}{l}6.89 \\
7.08\end{array}$ & 6.98 & $\begin{array}{l}6.27 \\
7.19\end{array}$ & 6.73 & $\begin{array}{l}.79 \\
.79\end{array}$ & .79 \\
\hline 200 & $\begin{array}{l}\text { K9-5 } \\
\text { K9-5 }\end{array}$ & $\begin{array}{l}\mathrm{D} \\
\mathrm{S}\end{array}$ & $\begin{array}{l}7.30 \\
8.64\end{array}$ & 7.97 & $\begin{array}{l}5.97 \\
6.52\end{array}$ & 6.25 & $\begin{array}{l}.82 \\
.77\end{array}$ & .80 \\
\hline 300 & $\begin{array}{l}\mathrm{K} 13 \\
\mathrm{~K} 13 \\
\mathrm{~K} 13-2 \\
\mathrm{~K} 13-2 \\
\mathrm{~K} 13-3 \\
\mathrm{~K} 13-3\end{array}$ & $\begin{array}{l}\mathrm{D} \\
\mathrm{S} \\
\mathrm{D} \\
\mathrm{S} \\
\mathrm{D} \\
\mathrm{S}\end{array}$ & $\begin{array}{l}7.13 \\
7.42 \\
8.54 \\
9.14 \\
8.19 \\
8.83\end{array}$ & 8.21 & $\begin{array}{l}5.87 \\
6.16 \\
5.57 \\
6.05 \\
5.87 \\
6.43\end{array}$ & 6.00 & $\begin{array}{l}.83 \\
.67 \\
.77 \\
.73 \\
.78 \\
.68\end{array}$ & .74 \\
\hline
\end{tabular}

The potash analyses on the older (1926) series for three years are also shown in Table 16.

Table 16. Potash Content of Leaves of Three Crops. Quantitative POTASH SERIES OF 1926

\begin{tabular}{|c|c|c|c|c|c|c|c|c|}
\hline Lbs. $\mathrm{K}_{2} \mathrm{O}$ & & & & & r cent & of $\mathrm{K}_{2} \mathrm{O}$ in 1 & - & 1928 \\
\hline & $\begin{array}{l}\text { Plot } \\
\text { No. }\end{array}$ & Grade & Plot & Average & $\overparen{\text { Plot }}$ & Average & Plot & Average \\
\hline & K11 & D & 6.96 & & 5.45 & & 3.63 & \\
\hline None & $\begin{array}{l}\text { K11 } \\
\text { K11-1 }\end{array}$ & $\begin{array}{l}\mathrm{S} \\
\mathrm{D}\end{array}$ & 7.03 & 7.00 & $\begin{array}{l}4.71 \\
6.00\end{array}$ & 5.46 & $\begin{array}{l}3.56 \\
4.09\end{array}$ & 4.07 \\
\hline & K11-1 & S & & & 5.67 & & 5.01 & \\
\hline & K12 & D & 7.20 & & 7.19 & & 5.74 & \\
\hline 100 & K12 & S & 7.33 & 7.27 & 7.18 & 7.00 & $\begin{array}{r}5.79 \\
5.35\end{array}$ & 5.55 \\
\hline & $\mathrm{K} 12-1$ & S & & & 6.58 & & 5.33 & \\
\hline & K9 & D & 7.97 & & 7.69 & & 6.27 & \\
\hline 200 & K9 & $\mathrm{S}$ & 8.32 & 8.15 & 7.97 & 7.64 & 7.01 & 6.69 \\
\hline & K9-1 & S & & & 7.10 & & 6.76 & \\
\hline
\end{tabular}

From an inspection of these tables we may draw the following conclusions :

1. Each increase in the amount of potash in the fertilizer up to 300 pounds $\mathrm{K}_{2} \mathrm{O}$ per acre increased the percentage of potash in the leaves. The increase was about one per cent for each 100 pounds of fertilizer potash.

2. For three successive years the percentage of $\mathrm{K}_{2} \mathrm{O}$ in the leaves declined steadily when all special carriers of potash were omitted from the fertilizer.

${ }^{1}$ Figures are on air-dry basis; water content, about seven per cent. 
3. A steady decline, but less pronounced, followed when the $\mathrm{K}_{2} \mathrm{O}$ was reduced to 100 pounds per acre.

4. A still smaller decline in percentage of potash was noticed when 200 pounds $\mathrm{K}_{2} \mathrm{O}$ per acre were used. Whether this is seasonal may be determined by analyses of future crops.

5. The fact that in the third year of the "no-potash" plots, the percentage of $\mathrm{K}_{2} \mathrm{O}$ in the seconds was no higher than in the darks might be interpreted as meaning that either: (1) The lower leaves normally serve as storage places for surplus potash, or (2) when potash is short it is translocated from the older leaves to the new growth.

6. The percentage of $\mathrm{CaO}$ has varied inversely with $\mathrm{K}_{2} \mathrm{O}$. This agrees with all our previous results.

7. The percentage of $\mathrm{MgO}$ was highest where no $\mathrm{K}_{2} \mathrm{O}$ was added to the fertilizer. The other rates of application, however, do not show any consistent differences in this respect. This is probably due to the fact that 1928 was a very wet year with a number of heavy leaching rains during the growing season, which resulted in a very low supply of $\mathrm{MgO}$ in the soil. If there had been an abundant supply of $\mathrm{MgO}$ in the soil probably we should have found the same relation to $\mathrm{K}_{2} \mathrm{O}$ and $\mathrm{CaO}$ as in previous years. 


\section{NITROGEN FERTILIZER EXPERIMENTS}

Six sets of experiments that deal with the nitrogen ration of the crop are being conducted on the station farm. Progress reports on four of these are presented on the following pages.

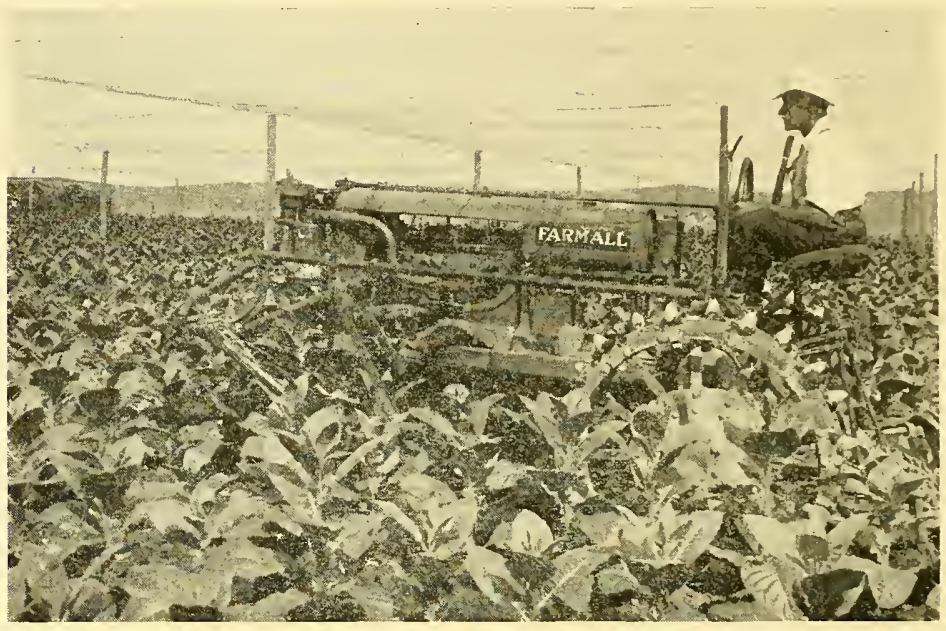

Figure 21. A two-row tractor cultivator at work in the Station tent.

\section{Urea as a Source of Nitrogen}

Progress on the turea experiments has been described in previous bulletins (Reports of the Tobacco Substation for 1925, page 12; 1926 , page 33 ; 1927, page 55 ; 1928, page 190). The plots on Fields II and IX were continued in 1930 in the same location and with the same fertilizer ration ${ }^{1}$ as in previous years. Fertilizer was applied on May 22 and the plants set on May 31. The tobacco was harvested on July 30 . No significant differences in the appearance of the plants were recorded during the summer. Although this set of plots has now been continued through six years on the same soil, at no time has there been any significant difference in their appearance in the field, regardless of the fertilizer treatment. The crop of 1929 was destroyed, but if one could judge from field appearance, the results would not have differed materially from those of the other years when the crop was sorted.

Another comparison between the standard formula and one in which one-half the nitrogen is furnished in urea was started in 1927 on two small plots on Field II. These are designated in the tables as N1-7 and N8-2.

\footnotetext{
${ }^{1}$ See Appendix for composition of formulas for plots N1, NS and N9.
} 
The yield and grading records for 1930 presented in Table 17 indicate that a formula in which urea is used to furnish half of the nitrogen produces at least as much tobacco of as good quality as a standard formula in which none of the nitrogen is from urea.

Table 17. Urea Plots. Yield and Grading of the Crop of 1930

\begin{tabular}{|c|c|c|c|c|c|c|c|c|c|c|c|c|c|}
\hline \multirow{2}{*}{$\begin{array}{c}\text { Amount of } \\
\text { urea } \\
\text { None }\end{array}$} & $\begin{array}{l}\text { Plot } \\
\text { No. }\end{array}$ & Plot & $\begin{array}{l}\text { e yield- } \\
\text { Average }\end{array}$ & L & $\mathrm{M}^{\mathrm{I}}$ & erce & $\begin{array}{l}\text { tage } \\
\text { SS }\end{array}$ & of $\mathrm{gr}$ & $\begin{array}{l}\text { ades } \\
\text { DS }\end{array}$ & $\mathrm{F}$ & B & \multicolumn{2}{|c|}{$\begin{array}{l}\text { Grade index } \\
\text { Plot Average }\end{array}$} \\
\hline & $\begin{array}{l}\text { N1-5 } \\
\text { N1-6 }\end{array}$ & $\begin{array}{l}1361 \\
1545\end{array}$ & 1453 & $\begin{array}{l}11 \\
15\end{array}$ & $\begin{array}{r}6 \\
13\end{array}$ & $\begin{array}{l}17 \\
20\end{array}$ & $\begin{array}{r}13 \\
6\end{array}$ & $\begin{array}{l}36 \\
31\end{array}$ & $\begin{array}{l}4 \\
4\end{array}$ & $\begin{array}{l}13 \\
11\end{array}$ & & $\begin{array}{l}.416 \\
.478\end{array}$ & .447 \\
\hline $\begin{array}{c}1 / 2 \mathrm{~N} \text { in } \\
\text { urea }\end{array}$ & $\begin{array}{l}\text { N8 } \\
\text { N8-1 }\end{array}$ & $\begin{array}{l}1460 \\
1630\end{array}$ & 1545 & $\begin{array}{l}14 \\
12\end{array}$ & $\begin{array}{l}8 \\
1\end{array}$ & $\begin{array}{l}20 \\
18\end{array}$ & $\begin{array}{l}8 \\
6\end{array}$ & $\begin{array}{l}32 \\
41\end{array}$ & $\begin{array}{l}5 \\
4\end{array}$ & $\begin{array}{l}13 \\
12\end{array}$ & & $\begin{array}{l}.451 \\
.431\end{array}$ & .441 \\
\hline $\begin{array}{c}\text { All } \mathrm{N} \text { in } \\
\text { urea }\end{array}$ & $\begin{array}{l}\text { N9 } \\
\text { N9-1 }\end{array}$ & $\begin{array}{l}1505 \\
1577\end{array}$ & 1541 & $\begin{array}{r}15 \\
6\end{array}$ & $\begin{array}{l}7 \\
4\end{array}$ & $\begin{array}{l}14 \\
15\end{array}$ & $\begin{array}{l}11 \\
19\end{array}$ & $\begin{array}{l}35 \\
46\end{array}$ & $\begin{array}{l}5 \\
8\end{array}$ & $\begin{array}{l}13 \\
12\end{array}$ & & $\begin{array}{l}.437 \\
.367\end{array}$ & .402 \\
\hline None & N1-7 & 1701 & & 9 & 9 & 27 & 4 & 37 & 2 & 12 & & .445 & .445 \\
\hline $\begin{array}{l}1 / 2 \mathrm{~N} \text { in } \\
\text { urea }\end{array}$ & N8-2 & 1610 & & 13 & 11 & 20 & 6 & 37 & 2 & 11 & & .460 & .460 \\
\hline
\end{tabular}

Tobacco from the plots where urea was the only source of nitrogen has not graded out quite as well as the others. As in previous years, so in the 1930 crop, it was found that the leaves of all grades from the all-urea plots were a shade darker and the veins were more prominent and light colored.

Since there are now records for five years on the plots of Field IX and for three years on the two small plots on Field II, we may summarize the entire series since its inception in 1925 in Table 18. One may draw the same conclusions from this table as from Table 17, namely, that a formula in which one half the nitrogen is in urea is as good as a standard formula in which there is no urea.

\section{Table 18. Urea Plots. Yield and Grading for Five Years}

\begin{tabular}{|c|c|c|c|c|c|c|c|c|c|c|c|c|}
\hline $\begin{array}{l}\text { Nitrogen } \\
\text { treatment }\end{array}$ & $\begin{array}{l}\text { Plot } \\
\text { No. }\end{array}$ & 1925 & $1926^{\circ}$ & $\begin{array}{c}\text { cree yie } \\
1927\end{array}$ & $\begin{array}{l}1 \mathrm{~d} \text { d by ye } \\
1928\end{array}$ & 1930 & Average & 1925 & ${ }_{1926}^{G}$ & $\begin{array}{r}\text { rade index by } \\
1927 \quad 1928\end{array}$ & $\begin{array}{l}\text { years } \\
1930\end{array}$ & Average \\
\hline No urea & $\begin{array}{l}\text { N1-5 } \\
\text { N1-6 }\end{array}$ & $\begin{array}{l}1364 \\
1561\end{array}$ & $\begin{array}{l}1501 \\
1711\end{array}$ & $\begin{array}{l}1060 \\
1296\end{array}$ & $\begin{array}{r}994 \\
1105\end{array}$ & $\begin{array}{l}1361 \\
1545\end{array}$ & 1350 & $\begin{array}{l}.268 \\
.411\end{array}$ & $\begin{array}{l}.492 \\
.473\end{array}$ & $\begin{array}{ll}.337 & .343 \\
.411 & .471\end{array}$ & $\begin{array}{l}.416 \\
.478\end{array}$ & .410 \\
\hline $\begin{array}{l}1 / 2 \mathrm{~N} \text { in } \\
\text { urea }\end{array}$ & $\begin{array}{l}\text { N8 } \\
\text { N8-1 }\end{array}$ & $\begin{array}{l}1365 \\
1597\end{array}$ & $\begin{array}{l}1488 \\
1695\end{array}$ & $\begin{array}{l}1053 \\
1441\end{array}$ & $\begin{array}{l}1109 \\
1170\end{array}$ & $\begin{array}{l}1460 \\
1630\end{array}$ & 1400 & $\begin{array}{l}.325 \\
.303\end{array}$ & $\begin{array}{l}.545 \\
.405\end{array}$ & $\begin{array}{ll}.354 & .430 \\
.446 & .434\end{array}$ & $\begin{array}{l}.451 \\
.431\end{array}$ & .412 \\
\hline $\begin{array}{l}\text { All } \mathrm{N} \text { in } \\
\text { urea }\end{array}$ & $\begin{array}{l}\text { N9 } \\
\text { N9-1 }\end{array}$ & $\begin{array}{l}1347 \\
1465\end{array}$ & $\begin{array}{l}1622 \\
1810\end{array}$ & $\begin{array}{l}1060 \\
1223\end{array}$ & $\begin{array}{l}1106 \\
1206\end{array}$ & $\begin{array}{l}1505 \\
1577\end{array}$ & 1392 & $\begin{array}{l}.257 \\
.352\end{array}$ & $\begin{array}{l}.489 \\
.445\end{array}$ & $\begin{array}{ll}.312 & .319 \\
.428 & .354\end{array}$ & $\begin{array}{l}.437 \\
.367\end{array}$ & .376 \\
\hline $\begin{array}{l}\text { No urea } \\
1 / 2 \mathrm{~N} \text { in }\end{array}$ & N1-7 & & & 1426 & 1157 & 1701 & 1428 & & & .499 .451 & .445 & .465 \\
\hline urea & N8-2 & & & 1386 & 1202 & 1610 & 1399 & & & .445 & .460 & .459 \\
\hline
\end{tabular}

In this connection, it may be pointed out that the feeding of urea to tobacco is not a new practice in the Connecticut Valley. For two hundred years before the first carload of cottonseed meal for fertilizer was imported from the South, the tobacco farmers of Connecticut grew their tobacco on a fertilizer in which approximately one half of the nitrogen was in urea, namely, stable manure. 
The urea that contains 40 to 60 per cent of the nitrogen in manure is chemically identical with the product now produced synthetically; the steps by which it breaks down in the soil and enters the growing tobacco plant and promotes growth are just the same, regardless of whether it came from the manure heap or the air nitrogen factory.

The most obvious advantage in substituting synthetic urea for cottonseed meal is the reduction in the fertilizer bill. The present cost of nitrogen in urea is less than half that of nitrogen in cottonseed meal. Some recent results obtained by the Soils Department (see page 435 of this Report) indicate that there is another possible advantage in using urea. After a leaching rain when all the available forms of nitrogen (nitrates mostly) have been washed away and the plant is in danger of being checked in its growth, urea seems to possess the ability of changing to an available form more quickly than cottonseed meal or other organics. In another set of experiments where single sources of nitrogen are being compared, it has been observed during every wet year that tobacco on the urea plots suffers but little from leaching, less so in fact than the cottonseed meal plot.

\section{Calurea as a Source of Nitrogen}

Calurea, a combination of urea and calcium nitrate in which four-fifths of the nitrogen is in the form of urea and one-fifth in calcium nitrate, has been found to be a cheap and favorable source of nitrogen in growing some crops. In order to determine its value in a tobacco fertilizer mixture, a series of 12 one-fortieth acre plots was started in 1928 on uniform soil on Field I. Three mixtures quite similar to the urea mixtures previously described were compared: (1) a standard mixture in which there was no Calurea, (2) one in which one-half of the nitrogen was in Calurea, and (3) one in which all the nitrogen was in Calurea. ${ }^{1}$ All treatments were in quadruplicate. Brief mention of this experiment was made in the Report for 1928 . The crop was destroyed in 1929 but during the three years of the experiment, no differences in growth as between the three different treatments could be observed in the field.

In 1930, the fertilizer was applied on May 22 and the plants set on June 2. All plots were harvested (the center row only kept for records) on August 5 and 6 . The sorting records are shown in Table 19 and the results for two years are summarized in Table 20. The differences in yield for the three treatments are too small to be considered significant. The grade index is somewhat lower where Calurea is the only source of nitrogen. Altogether, the results parallel very closely those from the urea tests.

'For complete composition, see Appendix, formulas N25, N26, and N27. 
Table 19. Calurea Series. Yield and Grading Records. Crop of 1930

\begin{tabular}{|c|c|c|c|c|c|c|c|c|c|c|c|c|}
\hline \multirow{4}{*}{$\begin{array}{l}\text { Calurea used } \\
\text { one (standard } \\
\text { formula) }\end{array}$} & $\begin{array}{l}\text { Plot } \\
\text { No. }\end{array}$ & \multicolumn{3}{|c|}{ Acreyield $\longrightarrow$} & $\begin{array}{l}\mathrm{Pet} \\
\mathrm{M}\end{array}$ & $\begin{array}{l}\text { enta } \\
\mathrm{LS}\end{array}$ & $\begin{array}{l}\text { ge } \\
\text { SS }\end{array}$ & $\begin{array}{l}\mathrm{f} g r \\
\mathrm{LD}\end{array}$ & $\begin{array}{l}\text { des- } \\
\text { DS }\end{array}$ & $\mathrm{F}$ & \multicolumn{2}{|c|}{$\begin{array}{l}\text { Grade index } \\
\text { Plot Average }\end{array}$} \\
\hline & $\mathrm{N} 25$ & 1959 & & 8 & 3 & 25 & 4 & 50 & 2 & 8 & .422 & \\
\hline & N25-1 & 1745 & & 19 & 9 & 22 & 7 & 32 & 3 & 8 & .507 & \\
\hline & N25-2 & 1675 & 1794 & 15 & 12 & 18 & 6 & 35 & 1 & 13 & .444 & .470 \\
\hline & N25-3 & 1798 & & 19 & 11 & 19 & 7 & 35 & 1 & 8 & .506 & \\
\hline Calurea & N26 & 2002 & & 14 & 9 & 19 & 4 & 42 & 1 & 11 & .459 & \\
\hline & N26-1 & 1728 & & 17 & 10 & 20 & 6 & 37 & 2 & 8 & .491 & \\
\hline & N26-2 & 1720 & 1799 & 12 & 8 & 21 & 5 & 42 & 1 & 11 & .448 & .463 \\
\hline & N26-3 & 1745 & & 12 & 11 & 19 & 6 & 42 & 1 & 9 & .455 & \\
\hline Calurea & N27 & 1932 & & 14 & 8 & 17 & 5 & 46 & 1 & 9 & .454 & \\
\hline & N27-1 & 1760 & & 17 & 8 & 16 & 9 & 42 & 1 & 7 & .476 & \\
\hline & $\mathrm{N} 27-2$ & 1651 & 1801 & 8 & 5 & 19 & 7 & 45 & 4 & 12 & .400 & .448 \\
\hline & N27-3 & 1861 & & 15 & 9 & 16 & 9 & 41 & 2 & 8 & .462 & \\
\hline
\end{tabular}

Tarle 20. Calurea Series. Summary of Two Years Results

\begin{tabular}{|c|c|c|c|c|c|c|c|}
\hline \multirow{2}{*}{ Amount of Calurea } & \multirow{2}{*}{$\begin{array}{l}\text { Plot } \\
\text { No. }\end{array}$} & \multicolumn{3}{|c|}{ Acre yiel } & \multicolumn{3}{|c|}{ Grade Index } \\
\hline & & 1928 & 1930 & Average & 1928 & 1930 & Average \\
\hline \multirow[t]{4}{*}{ None ........ } & N25 & 1300 & 1959 & & .387 & .422 & \\
\hline & N25-1 & 1140 & 1745 & & .404 & .507 & \\
\hline & $\mathrm{N} 25-2$ & 1174 & 1675 & 1508 & .419 & .444 & .436 \\
\hline & N25-3 & 1273 & 1798 & & .400 & .506 & \\
\hline \multirow{4}{*}{$\begin{array}{l}244 \text { lbs. to furn- } \\
\text { ish } 1 / 2 \text { of the } \\
\text { nitrogen .... }\end{array}$} & N26 & 1128 & 2002 & & .398 & .459 & \\
\hline & N26-1 & 1160 & 1728 & 1470 & .395 & .491 & 432 \\
\hline & N26-2 & 1257 & 1720 & 148 & .394 & .448 & .452 \\
\hline & N26-3 & 1092 & 1745 & & .413 & .455 & \\
\hline \multirow{4}{*}{$\begin{array}{l}488 \text { lbs. to furn- } \\
\text { ish all the } \\
\text { nitrogen } \ldots\end{array}$} & N27 & 1223 & 1932 & & .386 & .454 & \\
\hline & N27-1 & 1201 & 1760 & 1505 & .387 & .476 & 424 \\
\hline & $\mathrm{N} 27-2$ & 1113 & 1651 & & .400 & .400 & \\
\hline & N27-3 & 1298 & 1861 & & .425 & .462 & \\
\hline
\end{tabular}

\section{Nitrophoska Tests}

Nitrophoska (No. 3) is a concentrated commercial mixture containing 16.3 per cent nitrogen, 16.3 per cent phosphorus and 20 per cent potash. It contains no chlorine, the potash being in the form of sulfate. Obviously if such a fertilizer were found to be suitable for growing tobacco it would be less expensive than our usual mixtures, both on account of its original cost and because it is less bulky and would thus involve less labor in handling. An experiment was begun in 1929 to determine its suitability, (1) as the principal source of the elements included and, (2) as the source of half of the elements. These treatments are compared with the standard formula on six one-fortieth acre plots on a part of Field I, which has always produced the best tobacco on the farm. These plots are in duplicate and the soil is uniform.

The three formulas used are given in the appendix as N28, $\mathrm{N} 29$ and N30. The object of using a small quantity of urea in the N30 (all Nitrophoska) formula was to make the total quantity of nitrogen applied equal to the potash and thus correspond with 
our standard formula and customary practice. Carbonate of magnesia was also added to all three to prevent sand drown and to give a better burn. During 1929, observations in the field showed no difference between growth on the standard formula and the half-Nitrophoska formula. On the all-Nitrophoska formula, however, growth was not quite so large nor so uniform as on the others

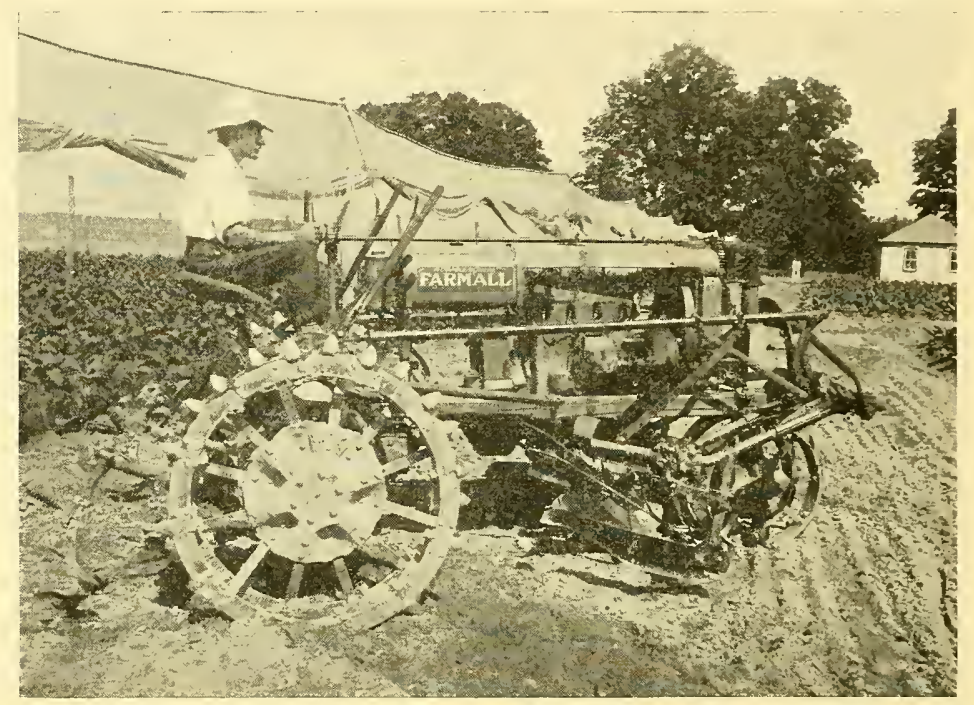

Figure 22. Arrangement of the Thompson attachments on the tractor for "hilling" shade tobacco.

at the time of the hailstorm that destroyed the crop on August 1. The same treatments, in duplicate, on the same plots were continued in 1930. Fertilizer was spread on May 22 and the plants set on June 2. During the summer the growth was good and uniform on all plots, no differences being apparent between the various treatments. All plots were harvested on August 5 (three rows of each plot, or about 150 plants, being kept for records).

Table 21. Nitrophoska Series. Yield and Grading Records. Crop of 1930

\begin{tabular}{|c|c|c|c|c|c|c|c|c|c|c|c|c|}
\hline Nitrophoska used & $\begin{array}{l}\text { Plot } \\
\text { No. }\end{array}$ & Plot & $\begin{array}{l}\text { eyield- } \\
\text { Averag }\end{array}$ & $\widetilde{L}$ & Merce & $\begin{array}{c}\text { entage } \\
\text { SS }\end{array}$ & $\begin{array}{l}\text { of } \\
\text { LD }\end{array}$ & & & & & $\begin{array}{l}\text { le index } \\
\text { Arerage }\end{array}$ \\
\hline $\begin{array}{c}\text { None } \\
\text { (standard formula) }\end{array}$ & $\begin{array}{l}\text { N28 } \\
\text { N28-1 }\end{array}$ & $\begin{array}{l}1884 \\
1829\end{array}$ & 1856 & $\begin{array}{l}15 \\
13\end{array}$ & $\begin{array}{ll}8 & 27 \\
6 & 26\end{array}$ & $\begin{array}{l}7 \\
4\end{array}$ & $\begin{array}{l}33 \\
39\end{array}$ & 1 & $\begin{array}{l}8 \\
9\end{array}$ & 2 & .491 & 477 \\
\hline & & $\begin{array}{l}1810 \\
1934\end{array}$ & 1872 & $\begin{array}{l}12 \\
11\end{array}$ & $\begin{array}{ll}3 & 27 \\
6\end{array}$ & $\begin{array}{l}5 \\
6\end{array}$ & $\begin{array}{l}44 \\
38\end{array}$ & & $\begin{array}{l}6 \\
9\end{array}$ & & $\begin{array}{l}.457 \\
.453\end{array}$ &.+55 \\
\hline & $\begin{array}{l}\text { N30 } \\
\text { N30-1 }\end{array}$ & $\begin{array}{l}1915 \\
1875\end{array}$ & 1895 & $\begin{array}{r}9 \\
13\end{array}$ & $\begin{array}{ll}6 & 27 \\
9 & 26\end{array}$ & $\begin{array}{l}3 \\
3\end{array}$ & $\begin{array}{l}41 \\
47\end{array}$ & & $\begin{array}{l}11 \\
10\end{array}$ & & $\begin{array}{l}.435 \\
.473\end{array}$ & .454 \\
\hline
\end{tabular}

Sorting records shown in Table 21 indicate no significant differences either in yield or grading. Neither do the observations taken 
at time of sorting show any real variations. All the tobacco on this field in 1930 had considerable white vein, but this apparently bore no relation to the fertilizer.

It is planned to continue this experiment through a series of years and possibly enlarge it by the addition of further replications. The only conclusion that may be drawn up to the present is that no falling off either in yield or quality occurred when Nitrophoska was used for two years on naturally strong land.

\section{Comparison of Nitrate of Soda and Nitrate of Lime as a Mineral Source of Nitrogen}

The object of this experiment was to compare the merits of these two quickly available nitrogen compounds when used to supply a portion of the nitrogen in the fertilizer mixture. Neither of them is suitable as the only source of nitrogen in a mixture because of too rapid leaching. A preliminary statement of this test, which was started in 1927, was published in our Report for 1928, page 191. There are four different treatments, ${ }^{1}$ in which (1) they are compared when each furnishes one-fifth of the nitrogen and (2) when each furnishes one-half of the nitrogen of the formula. Each treatment is in duplicate. The eight plots are located on Field III, where the soil is moderately uniform and crops are usually of only average size.

During the wet years, 1927 and 1928, tobacco on the plots where half of the nitrogen was in nitrate form turned noticeably more yellow than on the other plots, thus indicating that there had been considerable leaching away of the nitrogen. However, significant differences between the two kinds of nitrate did not appear, as far as could be judged from the tobacco in the field.

In 1930, the fertilizer was spread on May 22 and the plants set on June 2. No marked differences in appearance were recorded for 1930. The tobacco was harvested on August 7. The yield and grading records for the 1930 crop are presented in Table 22 and a summary of three years in Table 23.

Table 22. Comparison of Nitrate of Soma and Nitrate of Line. Yield and Grading Records. CRop of 1930

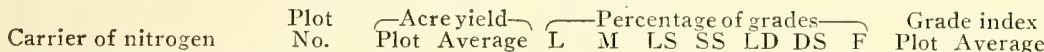

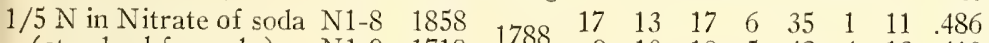

$\begin{array}{llllllllllll}\text { (standard formula) } & \text { N1-9 } & 1719 & 1788 & 9 & 10 & 18 & 5 & 42 & 4 & 12 & .419\end{array}$

$\begin{array}{llllllllrrrr}1 / 5 & \mathrm{~N} \text { in Nitrate } & \mathrm{N} 18 & 1795 & 1810 & 20 & 14 & 13 & 5 & 39 & 9 & .503\end{array}$ of lime

N18-1 1825

$1 / 2 \mathrm{~N}$ in Nitrate of soda

N2-3 1403

N2-4 1685

$1 / 2 \mathrm{~N}$ in Nitrate of lime

N16 1839

N16-1 1674

$\begin{array}{rrrrrrrrr}1544 & 7 & 9 & 22 & 5 & 35 & 7 & 15 & .405\end{array}$

$\begin{array}{rrrrrrrr}10 & 17 & 5 & 29 & 6 & 16 & .462 \\ 17 & 9 & 15 & 4 & 44 & & 11 & .469\end{array}$

$\begin{array}{rrrrrrrrr}1757 & 17 & 9 & 15 & 4 & 44 & & 11 & .469\end{array}$

.453

.461

.434

.432

${ }^{1}$ For composition of formulas see N1, N2, N16, and N18 in the Appendix. 
Table 23. Nitrate of Lime Series. Summary of Yield and Grade Index RECORDS FOR THREE YEARS

\begin{tabular}{|c|c|c|c|c|c|c|c|c|c|}
\hline \multirow{2}{*}{$\begin{array}{l}\text { Source } \\
\text { of nitrogen }\end{array}$} & \multirow{2}{*}{$\begin{array}{l}\text { Plot } \\
\text { No. }\end{array}$} & \multicolumn{4}{|c|}{-Acre yield- } & \multicolumn{4}{|c|}{-Grade index } \\
\hline & & 1927 & 1928 & 1930 & Average & 1927 & 1928 & 1930 & Average \\
\hline $\begin{array}{c}1 / 5 \text { in Nitrate } \\
\text { of soda }\end{array}$ & $\begin{array}{l}\text { N1-8 } \\
\text { N1-9 }\end{array}$ & $\begin{array}{l}1232 \\
1239\end{array}$ & $\begin{array}{l}1162 \\
1097\end{array}$ & $\begin{array}{l}1858 \\
1719\end{array}$ & 1385 & $\begin{array}{l}.386 \\
454\end{array}$ & $\begin{array}{l}.452 \\
463\end{array}$ & $\begin{array}{r}.486 \\
419\end{array}$ & .443 \\
\hline $\begin{array}{c}1 / 5 \text { in Nitrate } \\
\text { of lime }\end{array}$ & $\begin{array}{l}\text { N18 } \\
\text { N18-1 }\end{array}$ & $\begin{array}{l}1246 \\
1265\end{array}$ & $\begin{array}{l}1153 \\
1153\end{array}$ & $\begin{array}{l}1795 \\
1814\end{array}$ & 1407 & $\begin{array}{l}.385 \\
.387\end{array}$ & $\begin{array}{l}.446 \\
.446\end{array}$ & $\begin{array}{l}.503 \\
.419\end{array}$ & 431 \\
\hline $\begin{array}{c}1 / 2 \text { in Nitrate } \\
\text { of soda }\end{array}$ & $\begin{array}{l}\text { N2-3 } \\
\text { N2-4 }\end{array}$ & $\begin{array}{l}1145 \\
1185\end{array}$ & $\begin{array}{l}1098 \\
1080\end{array}$ & $\begin{array}{l}1403 \\
1685\end{array}$ & 1265 & $\begin{array}{l}.352 \\
.344\end{array}$ & $\begin{array}{l}.422 \\
.421\end{array}$ & $\begin{array}{l}.405 \\
.462\end{array}$ & .401 \\
\hline $\begin{array}{c}1 / 2 \text { in Nitrate } \\
\text { of lime }\end{array}$ & $\begin{array}{l}\text { N16 } \\
\text { N16-1 }\end{array}$ & $\begin{array}{l}1348 \\
1128\end{array}$ & $\begin{array}{l}1076 \\
1088\end{array}$ & $\begin{array}{l}1839 \\
1674\end{array}$ & 1359 & $\begin{array}{l}.457 \\
.386\end{array}$ & $\begin{array}{l}.40 S \\
.376\end{array}$ & $\begin{array}{l}.469 \\
.394\end{array}$ & .415 \\
\hline
\end{tabular}

These records show that there has been a marked reduction both in yield and grading where the larger quantities of nitrate of either kind were used. Such reduction has been greater where nitrate of soda was used than where nitrate of lime was applied.

\section{Burn Tests}

In order to see whether the kind or quantity of nitrate had any effect on the burn, both strip burn tests and cigar tests were made on the crops of 1927 and of 1928 . One hundred and sixty strip burn tests on each of the four grades and for each year and each treatment failed to show any differences in the fire-holding capacity. All had an average fire-holding capacity of 54 to 60 seconds. No tobacco raised on the farm had a better burn.

Some of the cigars had wrapper, binder and filler from the same plot ("clears"), while others had only the wrapper and binder. The fire-holding capacity of all was satisfactory, six to ten minutes. The color of the ash was a medium to dark gray, not light enough to be considered entirely satisfactory, but the different fertilizer treatments had no effect on this character. The coal band was narrow to medium, or even wide, and the coherence and evenness good. The taste and aroma were only fair.

Therefore, from the standpoint of combustion characteristics, we may conclude, from the crops of 1927 and 1928, that there was no difference between these two kinds of nitrates or the quantities used. 


\section{FRACTIONAL APPLICATION OF FERTILIZER}

On three one-twentieth acre plots on Merrimac coarse loamy sand on Field VII, the fertilizer was so divided that only a small part of the quickly available nitrogen was applied broadcast before setting, the remainder being divided and applied at the side of the growing plants on June 9 and June 27. On the adjacent check plots the same mixture in the same amount was broadcast on the field on May 23. The composition of the fertilizer for each application was as follows:

\begin{tabular}{|c|c|c|c|c|}
\hline \multirow[b]{2}{*}{ Carrier } & \\
\hline & $\begin{array}{c}\text { Broadcast } \\
\text { before setting }\end{array}$ & June 9 & June 27 & Total \\
\hline Cottonseed meal ........... & 200 & 400 & 400 & 1000 \\
\hline Castor pomace ........... & 1400 & & & 1400 \\
\hline Nitrate of lime $\ldots \ldots \ldots \ldots \ldots$ & & 100 & 100 & 200 \\
\hline Calurea ............. & 100 & & & 100 \\
\hline Nitrate of potash ... & & 50 & 60 & 110 \\
\hline Carbonate of potash & 90 & & & 90 \\
\hline Sulfate of potash ... & 117 & & & 117 \\
\hline Magnesia lime ... & 400 & & & 400 \\
\hline
\end{tabular}

This series of plots was started in 1926 and previous progress has been published in the Reports for 1927, page 57, and 1928, page 193. During 1926 and 1927 the results showed no advantage in fractional application. In the wet year of 1928, however, the benefit was quite apparent. (For details see Report for 1928.) In 1930 the first side dressing was applied during the heavy leaching rain of June 8 to 10 and again there was a distinct gain, both in yield and grading, as may be seen by reference to Table 24 . That the poor grading of the check plots was due to leaching of the available nitrogen may be inferred from the lighter color of the leaves on these plots in the field and the dead, yellow condition of the seconds on the sorting bench. The sorting records of these plots for four years are presented in Table 24a.

Table 24. Fractional Application Plots. Yield and Grading as Compared With Adjacent Plots where Fertilizer was in

One Application. Crop of 1930

\begin{tabular}{|c|c|c|c|c|c|c|c|c|c|c|c|c|c|}
\hline $\begin{array}{l}\text { Method of } \\
\text { fertilizer } \\
\text { application }\end{array}$ & $\begin{array}{l}\text { Plot } \\
\text { No. }\end{array}$ & $\overbrace{\text { Plot }}^{A c 1}$ & e yield $\longrightarrow$ & L & M & & $\begin{array}{l}\text { tage } \\
\text { SS }\end{array}$ & & $\begin{array}{c}\text { rade } \\
\text { DS }\end{array}$ & $\mathrm{F}$ & $\mathrm{B}$ & $\begin{array}{c}\text { Grad } \\
\text { Plot }\end{array}$ & $\begin{array}{l}\text { e index } \\
\text { Average }\end{array}$ \\
\hline Fractional & $\begin{array}{l}\text { F5-1 } \\
\text { F6 } \\
\text { F6-1 }\end{array}$ & $\begin{array}{l}1591 \\
1235 \\
1228\end{array}$ & 1351 & $\begin{array}{r}14 \\
2 \\
6\end{array}$ & $\begin{array}{r}10 \\
4 \\
9\end{array}$ & $\begin{array}{l}14 \\
12 \\
10\end{array}$ & $\begin{array}{r}7 \\
13 \\
9\end{array}$ & $\begin{array}{l}40 \\
32 \\
29\end{array}$ & $\begin{array}{r}2 \\
16 \\
19\end{array}$ & $\begin{array}{l}13 \\
21 \\
18\end{array}$ & & $\begin{array}{l}.442 \\
.304 \\
.344\end{array}$ & .363 \\
\hline $\begin{array}{l}\text { Single } \\
\text { application }\end{array}$ & $\begin{array}{l}\text { C3 } \\
\text { C3-1 } \\
\text { C5 } \\
\text { C5 } 1\end{array}$ & $\begin{array}{l}1120 \\
1260 \\
1157 \\
1243\end{array}$ & 1195 & 2 & 2 & $\begin{array}{r}7 \\
16 \\
15 \\
13\end{array}$ & $\begin{array}{l}8 \\
3 \\
7 \\
4\end{array}$ & $\begin{array}{l}23 \\
31 \\
31 \\
23\end{array}$ & $\begin{array}{r}20 \\
9 \\
14 \\
20\end{array}$ & $\begin{array}{l}24 \\
21 \\
20 \\
23\end{array}$ & $\begin{array}{l}18 \\
16 \\
13 \\
13\end{array}$ & $\begin{array}{l}.217 \\
.281 \\
.265 \\
.267\end{array}$ & .258 \\
\hline
\end{tabular}


Table 24a. Fractional Application Plots. Yield and Grading Recokds FOR FOUR YEARS

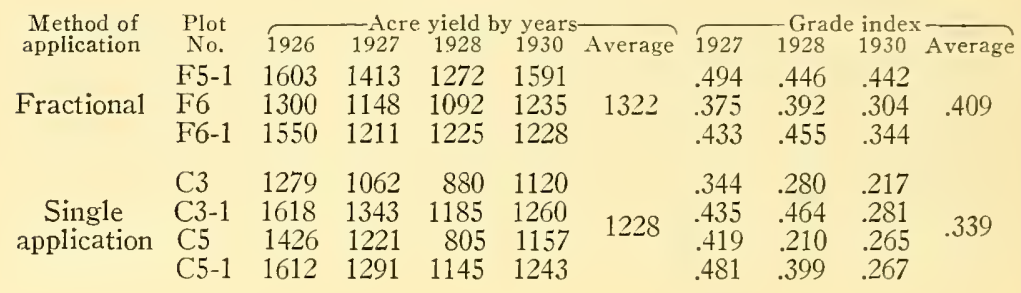

As a result of all fractional application experiments up to date on the station farm the following conclusions may be drawn:

1. During dry years, that is, years without leaching rains that follow the first application of fertilizer, a single broadcast application is more profitable both in yield and grading than fractional application of the same fertilizer.

2. In years when heavy leaching rains occur in the growing season, both yield and quality may be improved by reserving some of the quickly available nitrogen carriers for later applications.

3. Coarse sandy soils with porous subsoils subject to leaching, may be expected to show greater benefit from such later applications.

4. Timing such later applications is particularly important. Reference should be made not to the calendar nor to the time of hoeing, but to the time and character of the rains. After a heavy, leaching rain, the application should be made immediately, without waiting to see whether the leaves will turn pale.

From these conclusions, it is apparent that the better method of applying the fertilizer depends on whether it is a wet or a dry year. But it is obviously not possible to know beforehand what kind of a season is ahead. In order to be safe and to profit by either method, some growers follow this rule: Before setting, apply enough fertilizer to take care of all the nutrient requirements of the crop. Then, if leaching rains occur during the growing season, apply additional nitrogen at once. Obviously this increases the cost of the fertilizer throughout a series of years but probably the increase in yield and quality more than compensates for the extra cost.

The heavy rains of June, 1930, presented an opportunity for testing this rule. As previously stated, 100 pounds of nitrate of lime and 300 pounds of cottonseed meal per acre were applied to Field V, but not to Field VII. These two fields are adjacent, and on the same type of soil and on the check plots they receive the same fertilizer application. The average acre yield of the four 
check plots on Field VII for the years 1926, 1927 and 1928 was 1,239 pounds, as compared with 1,140 pounds for the two check plots on Field $\mathrm{V}$ for the same years, a difference of 99 pounds per acre in favor of Field VII. In 1930, however, the average for Field V was 1,509 , as compared with 1,195 for Field VII. A similar increase in grading is apparent by reference to Table 28. Such an increase more than pays for the additional cost of fertilizer. 


\section{MANURE AS A SUPPLEMENT TO COMMERCIAL FERTILIZER}

The purpose of this experiment was to see what effect the addition of manure to the regular commercial fertilizer ration has on the yield and quality of tobacco. The progress of the experiment, which was started in the autumn of 1925 on eight plots of Merrimac loamy coarse sand, Field VII, and has now been continued for five years, was discussed in Reports $^{1}$ for the years 1927, 1928 and 1929. One plot was treated annually with 20 loads (tons) per acre of mixed stable manure, another with 40 loads per acre, two others with about 30 loads of artificial (Adco) manure. Adjacent to each plot was a check plot of the same size and treated the same way throughout, except that it received no manure.

In the dry year of 1926 the differences in yield and grading between the manure and no-manure plots were so small and inconsistent it was apparent that the manure had been of little if any value. In the wet years of 1927 and 1928, tobacco on the manure plots seemed to suffer less from leaching and had a better appearance in the field. Both the yield and grade index were somewhat better on the manured plots in these wet years. See Table 26.

During the dry year of 1929 , however, the manured plots were extremely poor (as judged in the field, the crop being destroyed by hail) in contrast to the check plots. See Report for 1929.

\section{Crop of 1930}

In preparation for the crop of 1930 the manure was harrowed into the soil the previous fall. Commercial fertilizer was applied on May 22 and the plants set on May 27. After the heavy rains of June 8 to 10 a side dressing of 100 pounds nitrate of lime and 300 pounds of cottonseed meal per acre were applied to Field V on which the Adco manure and adjacent check plots were located. None, however, was applied to the other plots. All plots were irrigated twice during the latter part of July. All were harvested on July 31 and August 1.

Early in the growing season it was apparent that the manure plots were not doing so well as the check plots. This difference became more pronounced as the season advanced. This part of the farm suffered severely from the dry and excessively hot weather of the latter half of July. The growth was not normal on the check plots, but on the manure plots the plants were so stunted that from a commercial standpoint they would not have been worth harvesting. They wilted so much that the lower leaves were badly burned on the hot sand.

\footnotetext{
${ }^{1}$ Tobacco Substation Bull. 10: 62-66. 1928. Conn. Agr. Exp. Station Bulletins 299: 192. 1929, and 311: 216-219. 1930.
} 
Table 25. Manure Plots. Yield and Grading for Crop of 1930

Ki Plot $\rightleftharpoons$ Acre yield $\longrightarrow-$ Percentage of grades $\longrightarrow$ B Grade index

$\begin{array}{lcccccccccc}\text { Kind of manure } & \text { No. } & \text { Plot Average } & \text { L } & \text { M } & \text { LS SS } & \text { S LD } & \text { DS } & \text { F } & \text { B } & \text { Plot Average } \\ \text { Stable 20 loads } & \text { M1 } & 989 & 983 & & 16 & 54 & 30 & & .159 & .197\end{array}$

Stable 40 loads

$\begin{array}{lll}\text { M1 } & 989 & 983\end{array}$

None C3 1120

None H-H $1103 \quad 1210$

None

C3-1 1407

Adco manure

M2 1383

M2-1 1236

None

$\begin{array}{ll}\text { C14 } & 1516 \\ \text { C14 } & 1519\end{array}$

$\begin{array}{rrrrrrrr} & 1 & 3 & 16 & 3 & 31 & 9 & 21 \\ 1310 & 7 & 4 & 11 & 11 & 35 & 11 & 21 \\ & 7 & 8 & 8 & 12 & 31 & 16 & 18 \\ 1517 & 15 & 16 & 12 & 8 & 29 & 7 & 13 \\ & 11 & 12 & 18 & 8 & 32 & 4 & 13\end{array}$

$\begin{array}{lllll}6 & 18 & 17 & 35 & 24\end{array}$

.235

.197

$\begin{array}{lllllll}7 & 8 & 23 & 20 & 24 & 18 & .217\end{array}$

$\begin{array}{llllll}14 & 17 & 34 & 25 & 10 & .196\end{array}$

.231

The sorting records presented in Table 25 show a reduction in all cases of more than 200 pounds where manure was used. Also a corresponding falling off in grading. The larger yields on the Adco plots and their adjacent check plots are accounted for by the extra application of fertilizer that was made to these plots after the heavy rains of June.

Table 26. Manure Plots. Yields and Gradings for Four Years

\begin{tabular}{|c|c|c|c|c|c|c|c|c|c|c|c|}
\hline Kind of manure & $\begin{array}{l}\text { Plot } \\
\text { No. }\end{array}$ & $1926^{\circ}$ & 1927 & $\begin{array}{l}\text { Acre y } \\
1928^{*}\end{array}$ & $\begin{array}{l}\text { eld } \\
1930\end{array}$ & Average & 1926 & $\overline{1927}$ & $\begin{array}{l}\text { rrade } i \\
1928^{*}\end{array}$ & $\begin{array}{r}\text { ndex - } \\
1930\end{array}$ & Average \\
\hline Stable 40 loads & M1 & 1404 & 1375 & 1069 & 989 & & .338 & .480 & .319 & .159 & . \\
\hline Stable 20 loads & M1-1 & 1489 & 1402 & 1106 & 978 & & .396 & .391 & .435 & .235 & \\
\hline None & $\begin{array}{l}\text { C3 } \\
\text { C3-1 }\end{array}$ & $\begin{array}{l}1279 \\
1618\end{array}$ & $\begin{array}{l}1062 \\
1343\end{array}$ & $\begin{array}{r}880 \\
1185\end{array}$ & $\begin{array}{l}1120 \\
1407\end{array}$ & 1237 & $\begin{array}{l}.295 \\
.379\end{array}$ & $\begin{array}{l}.344 \\
.435\end{array}$ & $\begin{array}{l}.280 \\
.464\end{array}$ & $\begin{array}{l}.217 \\
.281\end{array}$ & .337 \\
\hline Adco 30 loads & $\begin{array}{l}\text { M2 } \\
\text { M2-1 }\end{array}$ & $\begin{array}{l}1379 \\
1281\end{array}$ & $\begin{array}{l}1259 \\
1300\end{array}$ & $\begin{array}{r}1129 \\
980\end{array}$ & $\begin{array}{l}1383 \\
1236\end{array}$ & 1243 & $\begin{array}{l}.328 \\
.298\end{array}$ & $\begin{array}{l}.442 \\
.482\end{array}$ & $\begin{array}{l}.457 \\
.277\end{array}$ & $\begin{array}{l}.430 \\
.345\end{array}$ & 332 \\
\hline None & $\begin{array}{l}\text { C14 } \\
\text { C14-1 }\end{array}$ & 1285 & $\begin{array}{l}1161 \\
1217\end{array}$ & $\begin{array}{l}912 \\
979\end{array}$ & $\begin{array}{l}1516 \\
1519\end{array}$ & 1227 & $\begin{array}{l}.305 \\
.274\end{array}$ & $\begin{array}{l}.350 \\
.368\end{array}$ & $\begin{array}{l}.287 \\
.351\end{array}$ & $\begin{array}{l}.456 \\
.433\end{array}$ & .353 \\
\hline
\end{tabular}

The yield and grading results of these plots for four years are presented in Table 26. The averages for the four years do not show any very striking differences, but averages do not tell the whole story. In the second and third years of the tests, manure undoubtedly improved both yield and grading. By the fourth year, 1929, however, the results were reversed and the manure plots were definitely inferior in appearance, and undoubtedly would have shown lower yields and grading if the hailstorm had not prevented taking records. In the fifth year the deterioration had progressed to such a point that the tobacco was worthless.

\section{Black Rootrot on the Manure Plots}

The field on which these tests are located has never been seriously affected by black rootrot, Thielavia basicola. In fact, rootrot is not commonly a factor on such coarse sandy soils. It has always

* Crop of 1929 destroyed by hail on August 1. 
been possible, however, to find occasional lesions of this disease on the roots. This is true of practically all old tobacco fields of this state, but it has been observed in the last two years that the tobacco on the manure plots wilted more quickly during hot days than the tobacco on the other parts of the field. This, coupled with its dark green color, lead us to suspect the presence of black rootrot. After the removal of the 1930 crop a wheelbarrow load of roots from each of the manure plots and from the adjacent check plots was dug and washed. Completely rotted roots and lesions in all stages of development were present in abundance on root systems from the manure plots, while only occasional lesions were found on the check plots.

The use of manure in such quantities on this land has thus greatly increased the prevalence of black rootrot and this is the most probable explanation of the decreasing yields. Bearing on this point also is an unpublished observation made during a series of experiments on brown rootrot at Poquonock from 1925 to 1928. Two manured plots in that experiment showed more black rootrot than any other plots on the field.

Data to show how manure decreases acidity of the soil were published in our Report for 1929, page 217. Decreased acidity favors rootrot. It is also probable that increase in the humus content of the soil would favor growth of the rootrot fungus.

\section{Increase in Soil Organic Matter from Use of Manure}

In order to see to what degree the application of manure increases the percentage of organic matter in this soil, analyses were made on two sets of samples, the first taken in the fall of 1927 and the second at about the same time in 1930 . The results of these analyses ${ }^{1}$ presented in Table 27 show that there has been an average increase of about 50 per cent in the organic matter content as a result of adding manure for the five years.

Table 27. Percentage of Organic Matter in Soll of Manure Plots

\begin{tabular}{|c|c|c|c|c|c|}
\hline \multirow{2}{*}{$\begin{array}{l}\text { Kind } \\
\text { of manure }\end{array}$} & \multirow{3}{*}{$\begin{array}{l}\text { Plot } \\
\text { No. } \\
\text { C3 } \\
\text { C3-1 } \\
\text { C14 } \\
\text { C14-1 }\end{array}$} & \multicolumn{2}{|c|}{$\begin{array}{l}\text { Percentage } \\
\text { of organic matter }\end{array}$} & \multirow{3}{*}{$\begin{array}{c}\text { Difference } \\
.023 \text { decrease } \\
.003 \text { increase } \\
.053 \text { decrease } \\
\text { no change }\end{array}$} & \multirow{2}{*}{$\begin{array}{l}\text { Average } \\
\text { for } 1930\end{array}$} \\
\hline & & & & & \\
\hline None & & $\begin{array}{l}1.350 \\
1.557 \\
1.491 \\
1.517\end{array}$ & $\begin{array}{l}1.333 \\
1.560 \\
1.438 \\
1.517\end{array}$ & & 1.462 \\
\hline Stable & $\begin{array}{l}\text { M1 } \\
\text { M1-1 }\end{array}$ & $\begin{array}{l}1.672 \\
1.815\end{array}$ & $\begin{array}{l}2.057 \\
2.477\end{array}$ & $\begin{array}{l}.385 \text { increase } \\
.662 \text { increase }\end{array}$ & \multirow{2}{*}{2.229} \\
\hline Adco & $\begin{array}{l}\text { M2 } \\
\text { M2-1 }\end{array}$ & $\begin{array}{l}1.655 \\
1.762\end{array}$ & $\begin{array}{l}2.408 \\
1.976\end{array}$ & $\begin{array}{l}.753 \text { increase } \\
.214 \text { increase }\end{array}$ & \\
\hline
\end{tabular}

${ }^{1}$ Made by Mr. Morgan and Dr. Lunt of the Soils Department according to the Parr-bomb method of determining carbon and calculating the organic matter by multiplying by the factor 1.724 . 


\section{Increase in Water-holding Capacity of Soil}

Since the use of manure has increased the organic matter content of this soil it would be reasonable to expect that the capacity of the soil for retaining moisture would also be increased. Theoretically, such an increase should be beneficial to the tobacco crop by reducing the ill effects of leaching on a wet year and of drought on a dry year. Determination of the water-holding capacity of the four manure plots and the four adjacent checks was made by the Soils Department in the fall of 1930 . The average water-holding capacity of the four check plots was 27.94 per cent, as contrasted with 30.63 per cent for the manure plots, thus showing a gain of 2.69 per cent in the five years. The fact that the plants on these manure plots do not show any resistance to wilting, but rather are less resistant than those on the check plots is thus apparently due to reduction of the absorbing root surface through black rootrot.

\section{Effect of Manure on the Burn}

In strip burn tests on single leaves (see Report for 1929, page 218 ) it was found that leaves from the manure plots possessed as good fire-holding capacity as those from the check plots. More recently, cigars were made from this tobacco of the crop of 1928. On these cigars it was found that the burn was usually somewhat superior on the manure plots, in that the ash was lighter colored. and the coal band narrower. Also in most cases, the taste and aroma were judged to be better. These differences may be due to the increase in magnesia from the manure; at least the effect is the same as was obtained in other experiments when the magnesia content of the leaves was increased. 


\title{
COVER CROP EXPERIMENTS
}

After the hailstorm of August 1, 1929, the tobacco was harrowed in and the cover crops sowed before August 10, this being one to two weeks earlier than the usual date for sowing them. Plenty of moisture was present and the fall weather was favorable for growth. Both the oats and the barley matured and much of it was headed out before freezing down in December. The vetch did not winter over very well. Most of it died before spring, but all others made an unusually large growth.

The crops were plowed under early in May and the following fertilizer mixture (per acre) applied on May 23.

\author{
1,000 ibs. cottonseed meal \\ 1,400 lbs. castor pomace \\ $200 \mathrm{lbs}$. nitrate of lime \\ 100 lbs. calurea \\ 110 lbs. nitrate of potash \\ $90 \mathrm{lbs}$. carbonate of potash \\ $117 \mathrm{lbs}$. sulfate of potash \\ 400 lbs. magnesian lime (29 per cent $\mathrm{MgO}$ )
}

This mixture furnishes 200 pounds each of nitrogen and potash and 58 pounds of phosphoric acid. The plants were set on May 27. After the heavy rains in June a side dressing of 100 pounds nitrate of lime and 300 pounds cottonseed meal per acre were applied to the plots on Field V, but not to those on Field VII. The tobacco on both fields was irrigated twice during the last ten days of July. This should have been started a week earlier for best results. All plots were harvested on July 31 and August 1.

Observations during the growing season indicated that on Field VII the cover crop plots were doing better than the check plots. This difference was not apparent on Field V, probably due to the second application of fertilizer. The oats plot on the south end (C9) did not do so well, probably because the lysimeter had been built on part of it and the remainder was used as a roadway for the tractor and other machinery. The rye and timothy plots looked best on this field.

The sorting records presented in Table 28 show a distinct benefit from the cover crops on Field VII, but none on Field V; in fact, the check plots are slightly better on the latter. This difference in results on the two fields may be explained on the assumption that the benefit derived from a cover crop is due to conservation of nitrogen or other elements that might otherwise leach away to a smaller degree. On Field $V$, the second application of fertilizer after the only leaching rain of the summer was sufficient to prevent any shortage of nutrients on any of the plots. Growth during the later part of the season was limited by the low supply of moisture rather than the supply of nutrients on this field. 
Table 28. Cover Crop Plots. Yield and Grading of Crop of 1930 Field VII

\begin{tabular}{|c|c|c|c|c|c|c|c|c|c|c|c|c|c|}
\hline Cover crop & $\begin{array}{l}\text { Plot } \\
\text { No. }\end{array}$ & $\overbrace{\text { Plot }}^{\text {Acr }}$ & & $\mathrm{L}$ & M & $\begin{array}{c}\text { Perc } \\
\text { LS }\end{array}$ & $\begin{array}{l}\text { ntagg } \\
\text { SS }\end{array}$ & $\begin{array}{l}e \text { of } \\
\text { LD }\end{array}$ & DS & $\mathrm{F}$ & B & $\begin{array}{l}\text { Grad } \\
\text { Plot }\end{array}$ & $\begin{array}{l}\text { index } \\
\text { verage }\end{array}$ \\
\hline \multirow[t]{2}{*}{ None } & $\begin{array}{l}\text { C3 } \\
\text { C3-1 } \\
\text { C5 } \\
\text { C5-1 }\end{array}$ & $\begin{array}{l}1120 \\
1260 \\
1157 \\
1243\end{array}$ & 1195 & 2 & $\begin{array}{l}3 \\
2\end{array}$ & $\begin{array}{r}7 \\
16 \\
15 \\
13\end{array}$ & $\begin{array}{l}8 \\
3 \\
1 \\
4\end{array}$ & $\begin{array}{l}23 \\
31 \\
31 \\
23\end{array}$ & $\begin{array}{r}20 \\
9 \\
14 \\
20\end{array}$ & $\begin{array}{l}24 \\
21 \\
20 \\
23\end{array}$ & $\begin{array}{l}18 \\
16 \\
13 \\
13\end{array}$ & $\begin{array}{l}.217 \\
.281 \\
.265 \\
.267\end{array}$ & .258 \\
\hline & C5mk & 1326 & 1326 & 2 & 4 & 14 & 4 & 34 & 14 & 18 & 10 & .298 & .298 \\
\hline Timothy & $\begin{array}{l}\text { C6 } \\
\text { C6-1 }\end{array}$ & $\begin{array}{l}1425 \\
1243\end{array}$ & 1334 & 4 & $\begin{array}{l}6 \\
8\end{array}$ & $\begin{array}{l}15 \\
15\end{array}$ & $\begin{array}{l}8 \\
3\end{array}$ & $\begin{array}{l}31 \\
36\end{array}$ & $\begin{array}{l}12 \\
10\end{array}$ & $\begin{array}{l}16 \\
18\end{array}$ & $\begin{array}{l}6 \\
6\end{array}$ & $\begin{array}{l}.349 \\
.339\end{array}$ & .344 \\
\hline & $\begin{array}{l}\text { C7 } \\
\text { C7-1 }\end{array}$ & $\begin{array}{l}1304 \\
1276\end{array}$ & 1290 & & $\begin{array}{l}4 \\
7\end{array}$ & $\begin{array}{l}19 \\
11\end{array}$ & $\begin{array}{l}5 \\
8\end{array}$ & $\begin{array}{l}41 \\
36\end{array}$ & $\begin{array}{l}6 \\
9\end{array}$ & $\begin{array}{r}17 \\
2\end{array}$ & $\begin{array}{l}5 \\
5\end{array}$ & $\begin{array}{l}.340 \\
.323\end{array}$ & .332 \\
\hline Rye & $\begin{array}{l}\text { C8 } \\
\text { C8-1 }\end{array}$ & $\begin{array}{l}1313 \\
1679\end{array}$ & & & $\begin{array}{l}8 \\
6\end{array}$ & $\begin{array}{l}17 \\
17\end{array}$ & $\begin{array}{r}11 \\
7\end{array}$ & $\begin{array}{l}32 \\
40\end{array}$ & $\begin{array}{l}7 \\
6\end{array}$ & $\begin{array}{l}16 \\
17\end{array}$ & 1 & $\begin{array}{l}.390 \\
.378\end{array}$ & .384 \\
\hline Oats & $\begin{array}{l}\text { C9 } \\
\text { C9-1 }\end{array}$ & $\begin{array}{l}1139 \\
1471\end{array}$ & 1305 & 9 & 10 & $\begin{array}{l}20 \\
20\end{array}$ & $\begin{array}{l}8 \\
6\end{array}$ & $\begin{array}{l}26 \\
32\end{array}$ & $\begin{array}{r}16 \\
8\end{array}$ & $\begin{array}{l}24 \\
15\end{array}$ & 6 & $\begin{array}{l}.284 \\
.415\end{array}$ & .350 \\
\hline Vetch & C10-1 & 1545 & 1545 & 9 & 11 & 17 & 5 & 35 & 7 & 15 & 1 & .408 & .408 \\
\hline
\end{tabular}

Field $\mathrm{V}$

\begin{tabular}{|c|c|c|c|c|c|c|c|c|c|c|c|c|c|}
\hline None & $\begin{array}{l}\text { C14 } \\
\text { C14-1 }\end{array}$ & $\begin{array}{l}1516 \\
1501\end{array}$ & 1509 & $\begin{array}{l}15 \\
11\end{array}$ & $\begin{array}{l}16 \\
12\end{array}$ & $\begin{array}{l}12 \\
18\end{array}$ & 8 & $\begin{array}{l}29 \\
32\end{array}$ & $\begin{array}{l}7 \\
4\end{array}$ & $\begin{array}{l}13 \\
13\end{array}$ & 2 & $\begin{array}{l}.456 \\
.433\end{array}$ & .445 \\
\hline Alfalfa & $\begin{array}{l}\text { C12 } \\
\text { C12-1 }\end{array}$ & $\begin{array}{l}1519 \\
1466\end{array}$ & 1492 & $\begin{array}{l}14 \\
10\end{array}$ & $\begin{array}{l}11 \\
12\end{array}$ & $\begin{array}{l}14 \\
12\end{array}$ & 0 & $\begin{array}{l}33 \\
37\end{array}$ & $\begin{array}{l}5 \\
8\end{array}$ & $\begin{array}{l}14 \\
16\end{array}$ & & $\begin{array}{l}.440 \\
.402\end{array}$ & .421 \\
\hline Redtop & $\begin{array}{l}\text { C13 } \\
\text { C13-1 }\end{array}$ & $\begin{array}{l}1524 \\
1367\end{array}$ & 1445 & $\begin{array}{l}13 \\
11\end{array}$ & $\begin{array}{l}14 \\
15\end{array}$ & $\begin{array}{r}15 \\
9\end{array}$ & 6 & $\begin{array}{l}32 \\
34\end{array}$ & $\begin{array}{l}5 \\
6\end{array}$ & $\begin{array}{l}15 \\
17\end{array}$ & & $\begin{array}{l}.443 \\
.409\end{array}$ & .426 \\
\hline Wheat & $\begin{array}{l}\text { C15 } \\
\text { C15-1 }\end{array}$ & $\begin{array}{l}1427 \\
1525\end{array}$ & 1476 & $\begin{array}{l}11 \\
11\end{array}$ & $\begin{array}{l}14 \\
14\end{array}$ & $\begin{array}{l}11 \\
17\end{array}$ & & $\begin{array}{l}36 \\
30\end{array}$ & $\begin{array}{l}5 \\
8\end{array}$ & $\begin{array}{l}16 \\
14\end{array}$ & $\begin{array}{l}1 \\
1\end{array}$ & $\begin{array}{l}.413 \\
.432\end{array}$ & .42 \\
\hline
\end{tabular}

The low yield and grade index of plot C9 for 1930 are a reverse of the results on this plot in previous years and should be disregarded, since proper cultural conditions were disturbed by the installation of the lysimeter in 1929. An examination of Table 29 shows that in previous years this plot has been fully equal to C9-1 both in yield and in grading. Assuming the same yield in 1930 for C9 as for C9-1, the average for the four years for the oats plot is 1,418, about the same as for rye and vetch (Table 29). During the dry year of 1929 the rye plots were about the poorest on the field. Rye seems to be an excellent cover crop for a wet year, or a year at least when there are rains soon enough after the crop is turned under to rot it, as in 1930. During very dry years like 1929, however, decay does not occur at the proper time to help the growing tobacco crop. Oats seem more reliable throughout a series of years. Vetch also gave very good results, but it was observed in the sorting that the tobacco was a shade darker than the other plots. The same fault has been observed in previous years. 
390

Table 29. Cover Crop Plots. Yield and Grading Records for Four Years Field VII

\begin{tabular}{|c|c|c|c|c|c|c|c|c|c|c|c|c|}
\hline Cover crop & $\begin{array}{l}\text { Plot } \\
\text { No. }\end{array}$ & 1926 & $\overline{1927}$ & $\begin{array}{l}\text { cre yit } \\
1928\end{array}$ & $d \longdiv { 1 9 3 0 }$ & Average & $\begin{array}{l}\text { verage } \\
\text { vent }\end{array}$ & 1927 & $\begin{array}{l}\text {-Grade } \\
1928\end{array}$ & $\begin{array}{l}\text { Index } \\
1930 \mathrm{~A}\end{array}$ & $\overrightarrow{\text { verage }}^{\mathrm{T}}$ & $\begin{array}{l}1 \text { reatme } \\
\text { averag }\end{array}$ \\
\hline None & $\begin{array}{l}\text { C3 } \\
\text { C3-1 } \\
\text { C5 } \\
\text { C5-1 }\end{array}$ & $\begin{array}{l}1279 \\
1618 \\
1426 \\
1612\end{array}$ & $\begin{array}{l}1062 \\
1343 \\
1221 \\
1291\end{array}$ & $\begin{array}{r}880 \\
1185 \\
805 \\
1145\end{array}$ & $\begin{array}{l}1120 \\
1260 \\
1157 \\
1243\end{array}$ & $\begin{array}{l}1085 \\
1352 \\
1152 \\
1323\end{array}$ & 1228 & $\begin{array}{l}.344 \\
.435 \\
.419 \\
.481\end{array}$ & $\begin{array}{l}.280 \\
.464 \\
.210 \\
.399\end{array}$ & $\begin{array}{l}.217 \\
.281 \\
.265 \\
.267\end{array}$ & $\begin{array}{l}.280 \\
.393 \\
.298 \\
.382\end{array}$ & .338 \\
\hline Muck & C.5mk & & & 1073 & 1326 & 1200 & & & .348 & .298 & .323 & \\
\hline Timothy & $\begin{array}{l}\text { C6 } \\
\text { C6-1 }\end{array}$ & $\begin{array}{l}1373 \\
1666\end{array}$ & $\begin{array}{l}1203 \\
1278\end{array}$ & $\begin{array}{l}1129 \\
1130\end{array}$ & $\begin{array}{l}1425 \\
1243\end{array}$ & $\begin{array}{l}1283 \\
1329\end{array}$ & 1306 & $\begin{array}{l}.450 \\
.443\end{array}$ & $\begin{array}{l}.371 \\
.342\end{array}$ & $\begin{array}{l}.349 \\
.339\end{array}$ & $\begin{array}{l}.390 \\
.375\end{array}$ & .383 \\
\hline Barley & $\begin{array}{l}\text { C7 } \\
\text { C7-1 }\end{array}$ & $\begin{array}{l}1430 \\
1507\end{array}$ & $\begin{array}{l}1296 \\
1357\end{array}$ & $\begin{array}{l}1177 \\
1057\end{array}$ & $\begin{array}{l}1304 \\
1276\end{array}$ & $\begin{array}{l}1302 \\
1299\end{array}$ & 1301 & $\begin{array}{l}.472 \\
.436\end{array}$ & $\begin{array}{l}.447 \\
.396\end{array}$ & $\begin{array}{l}.340 \\
.323\end{array}$ & $\begin{array}{l}.419 \\
.385\end{array}$ & .402 \\
\hline Rye & $\begin{array}{l}\text { C8 } \\
\text { C8-1 }\end{array}$ & $\begin{array}{l}1455 \\
1717\end{array}$ & $\begin{array}{l}1387 \\
1404\end{array}$ & $\begin{array}{l}1276 \\
1225\end{array}$ & $\begin{array}{l}1313 \\
1679\end{array}$ & $\begin{array}{l}1358 \\
1506\end{array}$ & 1432 & $\begin{array}{l}.480 \\
.488\end{array}$ & $\begin{array}{l}.480 \\
.445\end{array}$ & $\begin{array}{l}.390 \\
.378\end{array}$ & $\begin{array}{l}.450 \\
.437\end{array}$ & .443 \\
\hline Oats & $\begin{array}{l}\text { C9 } \\
\text { C9-1 }\end{array}$ & $\begin{array}{l}1687 \\
1621\end{array}$ & $\begin{array}{l}1356 \\
1371\end{array}$ & $\begin{array}{l}1310 \\
1070\end{array}$ & $\begin{array}{l}1139 \\
1471\end{array}$ & $\begin{array}{l}1371 \\
1383\end{array}$ & 1377 & $\begin{array}{l}.461 \\
.478\end{array}$ & $\begin{array}{l}.521 \\
.395\end{array}$ & $\begin{array}{l}.284 \\
.415\end{array}$ & $\begin{array}{l}.491 \\
.422\end{array}$ & .454 \\
\hline Vetch & $\begin{array}{l}\text { C10 } \\
\text { C10-1 }\end{array}$ & $\begin{array}{l}1642 \\
1479\end{array}$ & $\begin{array}{l}1430 \\
1399\end{array}$ & $\begin{array}{l}1172 \\
1258\end{array}$ & 1545 & $\begin{array}{l}1415 \\
1420\end{array}$ & 1418 & $\begin{array}{l}.392 \\
.434\end{array}$ & $\begin{array}{l}.474 \\
.554\end{array}$ & .408 & $\begin{array}{l}.433 \\
.465\end{array}$ & .449 \\
\hline \multicolumn{13}{|c|}{ Field V } \\
\hline None & $\begin{array}{l}\text { C14 } \\
\text { C14-1 }\end{array}$ & 1285 & $\begin{array}{l}1161 \\
1217\end{array}$ & $\begin{array}{l}912 \\
979\end{array}$ & $\begin{array}{l}1516 \\
1501\end{array}$ & $\begin{array}{l}1219 \\
1232\end{array}$ & 1224 & $\begin{array}{l}.350 \\
.368\end{array}$ & $\begin{array}{l}.287 \\
.351\end{array}$ & $\begin{array}{l}.456 \\
.433\end{array}$ & $\begin{array}{l}.371 \\
.384\end{array}$ & .377 \\
\hline Alfalfa & $\begin{array}{l}\text { C12 } \\
\text { C12-1 }\end{array}$ & $\begin{array}{l}1243 \\
1191\end{array}$ & $\begin{array}{l}1198 \\
1238\end{array}$ & $\begin{array}{l}1061 \\
1015\end{array}$ & $\begin{array}{l}1519 \\
1466\end{array}$ & $\begin{array}{l}1255 \\
1227\end{array}$ & 1241 & $\begin{array}{l}.435 \\
.430\end{array}$ & $\begin{array}{l}.344 \\
.325\end{array}$ & $\begin{array}{l}.440 \\
.402\end{array}$ & $\begin{array}{l}.406 \\
.386\end{array}$ & .396 \\
\hline Redtop & $\begin{array}{l}\text { C13 } \\
\text { C13-1 }\end{array}$ & $\begin{array}{l}1104 \\
1174\end{array}$ & $\begin{array}{l}1212 \\
1240\end{array}$ & $\begin{array}{l}1115 \\
1080\end{array}$ & $\begin{array}{l}1524 \\
1367\end{array}$ & $\begin{array}{l}1239 \\
1215\end{array}$ & 1227 & $\begin{array}{l}.399 \\
.455\end{array}$ & $\begin{array}{l}.447 \\
.344\end{array}$ & $\begin{array}{l}.443 \\
.409\end{array}$ & $\begin{array}{l}.430 \\
.403\end{array}$ & .416 \\
\hline Wheat & $\begin{array}{l}\text { C15 } \\
\text { C15-1 }\end{array}$ & $\begin{array}{l}1364 \\
1137\end{array}$ & $\begin{array}{l}1261 \\
1210\end{array}$ & $\begin{array}{l}951 \\
970\end{array}$ & $\begin{array}{l}1427 \\
1525\end{array}$ & $\begin{array}{l}1251 \\
1211\end{array}$ & 1231 & $\begin{array}{l}.377 \\
.448\end{array}$ & $\begin{array}{l}.332 \\
.367\end{array}$ & $\begin{array}{l}.413 \\
.432\end{array}$ & $\begin{array}{l}.374 \\
.416\end{array}$ & 59. \\
\hline
\end{tabular}




\section{THE RELATION OF MAGNESIA TO THE BURNING QUALITIES OF CIGAR LEAF TOBACCO}

In previous publications of this Station concerning the effects of treating tobacco soils with lime or limestone (containing both calcium and magnesium), the following conclusions were drawn:

1. Liming reduces the fire-holding capacity of the leaves if this capacity is measured by the strip test (single leaf), but,

2. When the same leaves are rolled into a cigar, the fire-holding capacity of the cigar is not only as good, but usually somewhat better, than that of a cigar made from unlimed tobacco.

3. Liming the land improves the color of the ash, making it light gray or white in contrast to the dark gray to black ash of the unlimed cigar.

4. Too much lime, however, makes the ash "flaky" (therefore objectionable).

5. The burn is much closer (that is, the coal band very narrow) on the cigar made from limed tobacco.

6. The taste and aroma are improved by liming.

7. Chemical analyses of the leaves show that liming greatly increases the magnesia, but reduces the calcium and potassium content of the tobacco.

Since the decrease in calcium and potassium would not be expected to produce such changes in the character of combustion, and since such decrease is merely a result of the greater increase in magnesium, we are warranted in concluding that the improved zombustion is due to absorption of larger amounts of magnesium by the plant.

A more extensive test of the comparative burning qualities of imed and unlimed tobacco was conducted on the leaves from three Jlots of the 1928 crop.

The three plots were fertilized as follows:

Fertilizer material

Cottonseed meal

Vitrate of soda $\ldots \ldots \ldots \ldots \ldots \ldots \ldots$

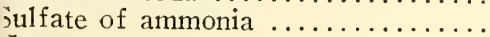

Jrea $\ldots \ldots \ldots \ldots \ldots \ldots \ldots \ldots \ldots \ldots \ldots \ldots$

recipitated bone $\ldots \ldots \ldots \ldots \ldots \ldots \ldots$

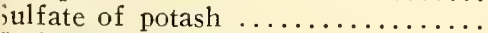

arbonate of potash ............

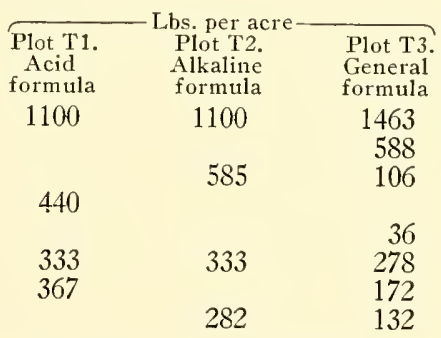

Each of these formulas furnished 200 pounds ammonia, 200 rounds potash and 160 pounds phosphoric acid to an acre.

One-half of each of the plots was limed each year from 1924 to 927 , inclusive, at the rate of one ton hydrated lime per acre. They vere not limed in 1928. Although magnesian lime was used, the 
actual percentage of $\mathrm{MgO}$ was not recorded. In the tables below the limed end of the plot is designated as $a$ and the unlimed as $b$.

After the tobacco had been fermented and aged for a year, the fire-holding capacity was first tested by the strip test on individual leaves. Then some of the leaves were made into cigars and the combustion tested. The ash from the cigars was then analyzed for magnesium, calcium and potassium.

\section{The Strip Test}

In making this test, the leaf is stretched between the hands and ignited by an incandescent electric filament. The number of seconds during which the fire, or glow, will continue to spread from the edge of the burned hole, after removal from the filament, is recorded as the fire-holding capacity. Twenty tests are made on each hand of tobacco and since four grades of leaves are included in each plot, the fire-holding capacity of any lot of tobacco is the average of 80 tests. Table 30 shows the average fire-holding capacity of each of the plots for the crop of 1928 . Since these same tests were conducted on the three preceding crops, the average fire-holding capacity for the four years is also presented.

\section{Tabie 30. Strip Burn Tests on Lime Plots}

Fire-holding capacity in seconds

\begin{tabular}{|c|c|c|c|c|c|}
\hline \multirow[b]{2}{*}{ Character of fertilizer } & \multirow{2}{*}{$\underset{\text { treatment }}{\operatorname{Lime}}$} & \multicolumn{4}{|c|}{$\tau_{-}$Average fire-holding capacity } \\
\hline & & $\overbrace{\text { Plot }}^{\mathrm{Cr}_{\mathrm{T}}}$ & $\begin{array}{l}\text { Treatment } \\
\text { Tren }\end{array}$ & $\begin{array}{c}\text { Crops o } \\
\text { Plot }\end{array}$ & $\begin{array}{l}\text { f } 1925 \text { to } 1928 \\
\text { Treatment }\end{array}$ \\
\hline Acid (T1) . & $\begin{array}{l}\text { Lime } \\
\text { No lime }\end{array}$ & $\begin{array}{l}21 \\
36\end{array}$ & 29 & $\begin{array}{l}16 \\
31\end{array}$ & 24 \\
\hline Alkaline (T2) & $\begin{array}{l}\text { Lime } \\
\text { No lime }\end{array}$ & $\begin{array}{l}48 \\
55\end{array}$ & 52 & $\begin{array}{l}37 \\
49\end{array}$ & 43 \\
\hline Neutral (T3) & $\begin{array}{l}\text { Lime } \\
\text { No lime }\end{array}$ & $\begin{array}{l}38 \\
55\end{array}$ & 47 & $\begin{array}{l}29 \\
47\end{array}$ & 38 \\
\hline
\end{tabular}

The data presented in Table 30 show that in every comparison, fire-holding capacity has been reduced by liming. This has been apparent during each of the four years of the test. The poor fireholding capacity of the T1 plots as compared with the others is probably due to the large amount of sulfate of ammonia used in this fertilizer.

\section{The Cigar Test}

After sweating and re-sweating the tobacco from the above plots, leaves from the same hands as tested above were used to make clear cigars, that is, filler, binder and wrapper from the same hand. After ageing for a few weeks, these cigars were smoked and records were taken on length of time they would hold fire, color and coherence of ash, closeness of burn, taste and aroma. The results are recorded in Table 31 . 


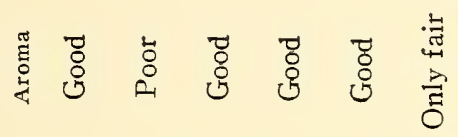

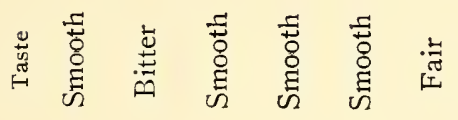

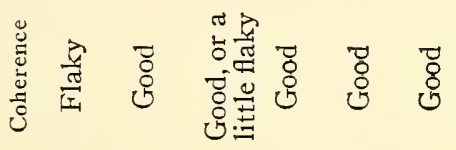

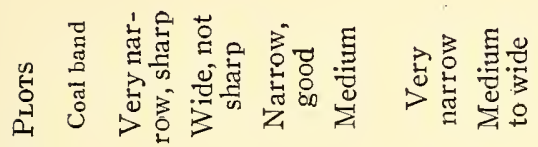

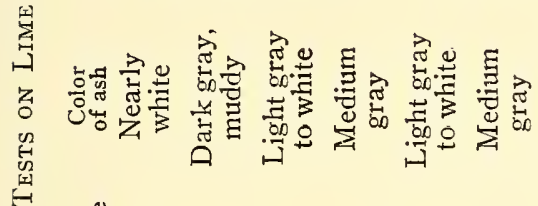

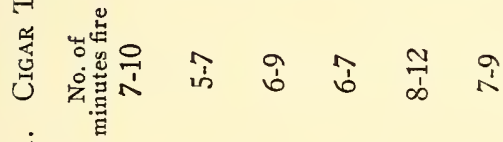

$$
\begin{aligned}
& \text { लं }
\end{aligned}
$$

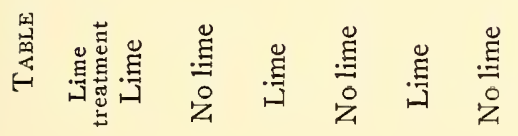

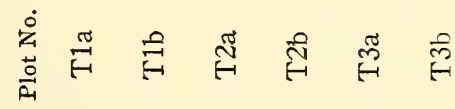

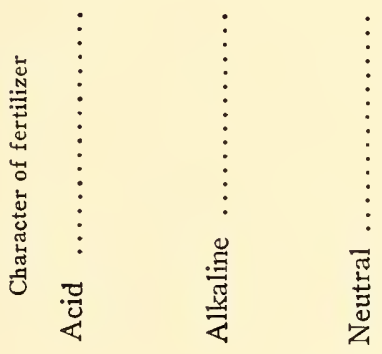


Six cigars were made from each plot. To test the fire-holding capacity, the cigar was well started, then laid on the ash tray, and at the end of five minutes or more it was tried to see whether the burn still held. In this way four or five tests could be made on each cigar. The figures given in the table show the shortest and the longest time during which each cigar remained alight.

It will be noted from Table 31 that cigars from the limed plots held fire longer than those from the unlimed plots, thus reversing the results from the strip tests. Also the cigars from the limed plots had a lighter colored ash and a narrower coal band and in general were superior in taste and aroma. In two of the plots, the ash was inclined to flake, but this tendency was probably not marked enough to be a serious objection. The ash from the T1b plot was very dark and also had a brownish cast which is designated as "muddy." This was the worst burning plot of all.

\section{Chemical Analyses}

The ash from the test cigars was analyzed for magnesium, calcium and potassium. Results of the analyses are presented in Table 32.

Table 32. Chemical, Analyses of the Tobacco from the Test Plots (Percentage of water free weight)

\begin{tabular}{|c|c|c|c|c|c|}
\hline \multirow{3}{*}{$\begin{array}{l}\text { Character of fertilizer } \\
\text { Acid } \ldots \ldots \ldots \ldots \ldots \ldots\end{array}$} & \multirow{3}{*}{$\begin{array}{c}\text { Lime } \\
\text { treatment } \\
\text { Lime } \\
\text { None }\end{array}$} & \multirow{3}{*}{$\begin{array}{l}\text { Plot No. } \\
\qquad \text { T1a } \\
\text { T1b }\end{array}$} & \multirow{2}{*}{\multicolumn{3}{|c|}{$\begin{array}{l}\text { Pagnesium Calcium oxides- } \\
\text { Potassium }\end{array}$}} \\
\hline & & & & & \\
\hline & & & $\begin{array}{l}2.66 \\
0.93\end{array}$ & $\begin{array}{l}4.94 \\
5.12\end{array}$ & $\begin{array}{l}6.40 \\
9.87\end{array}$ \\
\hline Alkaline & $\begin{array}{l}\text { Lime } \\
\text { None }\end{array}$ & $\begin{array}{l}\mathrm{T} 2 \mathrm{a} \\
\mathrm{T} 2 \mathrm{~b}\end{array}$ & $\begin{array}{l}1.82 \\
0.72\end{array}$ & $\begin{array}{l}4.09 \\
6.10\end{array}$ & $\begin{array}{l}7.42 \\
7.82\end{array}$ \\
\hline Neutral & $\begin{array}{l}\text { Lime } \\
\text { None }\end{array}$ & $\begin{array}{l}\text { T3a } \\
\text { T3b }\end{array}$ & $\begin{array}{l}2.10 \\
1.40\end{array}$ & $\begin{array}{l}4.71 \\
4.93\end{array}$ & $\begin{array}{l}7.69 \\
8.55\end{array}$ \\
\hline
\end{tabular}

These analyses are in line with those that have been reported in previous investigations of this Station. They show that when magnesian lime is applied to the soil, there is a decided increase in the magnesium found in the leaf and a smaller decrease in calcium. Similar results were obtained when tobacco of these plots from the crop of 1927 (Connecticut Agricultural Experiment Station Bulletin 311, Table 20) and from the crop of 1926 (Connecticut Agricultural Experiment Station Bulletin 306, Table 5) was analyzed.

\section{Discussion}

The more extensive and more detailed investigation of the crop of 1928 confirms the conclusions from previous investigations as stated in the beginning of this section. It may, therefore, be 
regarded as established that a certain percentage of magnesia in the leaf is essential to produce a satisfactory type of combustion in the cigar. The optimum percentage for tobacco grown under the conditions of this test is nearly 2 per cent. The percentage on the $b$ plots of 1928 (about 1 per cent) did not give a satisfactory ash. In previous tests a percentage of 1.5 did not always produce as white an ash as desirable, while a 3.5 per cent content made the ash too flaky.

It has been shown by Garner and collaborators ${ }^{1}$ that the minimum magnesia requirement of the tobacco plant is about .4 per cent of the dry weight of the leaf, that is, that much is necessary to prevent premature breaking down of chlorophyll and the appearance of magnesia hunger symptoms. The minimum requirement for normal growth, however, is only about one-fifth of the amount that is necessary for a desirable combustion of tobacco grown under the conditions of our test.

From a practical standpoint it is important to determine how much magnesia should be applied to an acre of land in order to produce tobacco with a magnesia content of 2 per cent. Obviously this cannot be determined very closely, because there is variation in the natural magnesia content of different soils and also because magnesia leaches readily. More would be required during a wet year than during a dry year, and more on a soil with a tendency to leach than on other soils. In the plots that have been discussed, the actual amount of magnesia applied each year was not recorded. Some indication may be obtained, however, from other plots on the Station farm where the magnesia applied was known. On some plots where 60 pounds $\mathrm{MgO}$ were applied annually for several years, the crop of 1925 was found to contain 2.05 per cent (Tobacco Substation Bulletin 10, page 43). On some other plots where 89 pounds of $\mathrm{MgO}$ had been applied yearly in double sulfate of potash magnesia, the 1926 crop had a magnesia content of 2.13 per cent, while adjacent plots that had received 52 pounds per acre had a content of 1.56 per cent $\mathrm{MgO}$ (Connecticut Agricultural Experiment Station Bulletin 299: 158).

With our present incomplete knowledge, probably the best recommendation that can be made to the grower whose tobacco burns unsatisfactorily with respect to the points mentioned, is that he apply 75 to 100 pounds of $\mathrm{MgO}$. If this does not produce a satisfactory burn, the dose may be repeated or increased the next year. The inclusion of such large quantities of magnesia in all fertilizer mixtures or in fact their general use, is not to be recommended, except where a whiter ash and closer burn are desired.

There are a number of fertilizer materials and soil amendments that may be used to supply the desired magnesia. The organic

${ }^{1}$ Jour. Agr. Res. 40: 148, 1930. 
materials of the fertilizer mixture contain small amounts of magnesia. Cottonseed meal averages about .7 per cent, castor pomace .8 per cent, linseed meal .7 per cent, fish meal .4 per cent, and tobacco stems about 1 per cent; manure also has a small but variable percentage, .1 or .2 per cent on a wet basis. Where a considerable quantity of organic material is applied in the fertilizer, there is usually enough magnesia present to prevent magnesia hunger but not enough to change a dark ash to a light gray or white one. A heavy coat of 20 tons of horse manure, however, would supply 80 pounds of magnesia per acre, and should be sufficient. Double manure salts (sulfate of potash magnesia) contains 11 per cent of magnesia and is commonly used to supply this element. It has the disadvantage, however, of also containing 46 per cent of sulfate and around 2 per cent of chlorine.

Cotton hull ash is another source of magnesia. It contains about one-half as much as double manure salts and only a small percentage of sulfur and chlorine. It also contains about 25 per cent of potash and 3 per cent of phosphoric acid. Where it is desirable to increase the magnesia application radically without increasing the fertilizer material too much, magnesian lime or limestone (with an $\mathrm{MgO}$ content of 25 per cent or more) is inexpensive and effective. It may be mixed with the fertilizer or applied separately. It also has the advantage of supplying calcium, which is used in large quantity by the tobacco crop. On land that has a high $\mathrm{pH}$ however, the use of lime must be avoided, since it promotes black rootrot. The use of pure magnesium salts such as carbonate or sulfate is not to be recommended in greater quantities, since such salts are known to be toxic to plants, and further investigation of their effect on tobacco should precede any general recommendation.

In these experiments, the strip test was not a true indication of the combustion qualities of the tobacco; that is, the cigar test reversed the conclusion that would have been drawn from the strip test alone, with respect to the relative combustion of the two lots of tobacco. This raises the question as to the value of the strip test, a method that has been used by both European and American investigators for many years, as well as by packers and dealers and manufacturers in the trade. Apparently, in this case at least, it involves the danger of leading to erroneous conclusions. Other factors besides the percentage of magnesia may be present, which may show the same reverse relation. This possibility is generally recognized, however, by experienced dealers in tobacco. Even though the strip test shows that the fire-holding capacity is not so good, they first try the combustion of the cigar before judging the tobacco. Frequently they find the tobacco satisfactory on the cigar whereas it would have been refused on the basis of the strip test. 


\section{Comparative Value of Calcium and Magnesium for Improving Combustion}

Calcium salts are also considered beneficial in making the ash of the cigar white. In order to compare the value of the two in this respect an experiment was conducted in which was compared the effect of very large quantities of pure calcium carbonate and of pure magnesium carbonate applied to the soil.

Thirty-six large crocks were filled with soil from plots that had grown tobacco for four years without fertilizer or lime and therefore had a very low calcium and magnesium content. Fertilizer containing an adequate supply of nitrogen, phosphorus, and potassium was added to each. Twelve of the pots received an application of pure calcium carbonate at the rate of five tons per acre; 12 more received pure magnesium carbonate at the rate of 3.7 tons per acre (molecular equivalent of the five tons of calcium carbonate), and the other 12 had no application of calcium or magnesium and served as checks. One tobacco plant was raised in each crock. It was found that the amount of magnesium carbonate applied was toxic and the plants died quickly. The amount was then reduced to 1.8 tons per acre and the plants grew normally. Cigars were made from the leaves harvested from the three treatments. When these were smoked, the following observations were made:

Cigars from the check plants burned with a coal black ash, but held fire fairly well.

Cigars from the calcium treated plants burned with a very dark gray ash and a narrow coal band, and did not hold fire quite as well as the check.

Cigars from the magnesium treated plants burned with a snow white ash and a very narrow coal band. Held fire very poorly.

From these tests it may be concluded that calcium makes the ash a little lighter, but that its influence is very weak compared with the whitening effect of magnesium.

Samples of the tobacco were analyzed for percentage of bases with results as follows:

\begin{tabular}{|c|c|c|c|}
\hline \multirow{2}{*}{ Treatment } & \multicolumn{3}{|c|}{ - Percentage (air dry basis) of } \\
\hline & Potash $\left(\mathrm{K}_{2} \mathrm{O}\right)$ & Lime $(\mathrm{CaO})$ & $\begin{array}{c}\text { Magnesia } \\
(\mathrm{MgO})\end{array}$ \\
\hline Che & 8.57 & 3.84 & 0.57 \\
\hline Calcium carbonate ....... & 7.73 & 6.78 & 0.41 \\
\hline Magnesium carbonate .......... & 2.88 & 2.05 & 4.74 \\
\hline
\end{tabular}

Although the percentage of calcium in the leaf was almost doubled by treatment of the soil with calcium carbonate, the ash was still much too dark to be satisfactory. A smaller amount of magnesium carbonate applied to the soil increased by 800 per cent the magnesia content of the leaves and made the ash snow white. This large amount of magnesia, however, reduced the percentage 
of potash in the leaf to less than 3 per cent, a shortage that accounts for the very low fire-holding capacity.

These treatments were necessarily extreme in order to magnify the effects of the different bases. The results emphasize the danger of using too much magnesium. This element is absorbed greedily by the tobacco plant and even though it may not be in large enough quantity to be toxic to growth, it may reduce the percentage of potassium to a point that, even on the cigar, will ruin the fire-holding capacity. The grower should keep in mind that the excessive use of magnesium salts may be more disastrous than a shortage of magnesium. 


\title{
EFFECT OF TOPPING AND SUCKERING ON DEVELOP- MENT OF THE TOBACCO PLANT
}

\author{
Th. Berthold
}

Topping and suckering the tobacco plant produces a better growth of leaves and therefore is practiced by growers to increase the yield. Experiments to determine the effect of topping and suckering on the yield of leaves and improvement of the quality have been made in many places. The principal object of the test described below, on the other hand, was to determine the influence of these treatments on the development of the root system of the plant. In 1928 the writer ${ }^{2}$ found that topping, besides producing a better development of the leaves, stimulates growth of the roots.

For the promotion of these studies the writer is indebted to Dr. Anderson, Pathologist in charge of the Tobacco Substation, where the tests described were carried out.

The field on which the test tobacco (Connecticut Havana seed) grew was a leachy, sandy soil that received only commercial fertilizer. The plants were set on May 31, 1930. Until the latter part of July, the weather conditions were favorable, but the month of August was too dry for best growth. For every treatment about 30 plants were used. The treatment was as follows:

\section{Early topping}

1a. High-topped and suckered

1b. High-topped and not suckered

1c. Low-topped and suckered

1d. Low-topped and not suckered
2. Late topping

2b. High-topped and not suckered

2a. High-topped and suckered

2c. Low-topped and suckered

2d. Low-topped and not suckered

3. Checks

3a. Suckered only.

3b. Untreated (neither topped nor suckered)

Most of the plants of Series I were topped on July 16 and the remainder on July 21, at which time none of the flowers had opened. Late topping was done on July 28, after all plants had blossomed. The suckers were removed in a young stage of growth. The harvest took place on August 18 and 19, and from every treatment 15 plants were harvested and the yield of leaf of each plant was determined. At the same time the plants were marked, carefully dug, and the roots washed for examination.

As may be seen in Table 33 the low-topped had an average of three to four leaves less than the high-topped. It should be mentioned that it is difficult at the time of topping, especially the

\footnotetext{
${ }^{1}$ Assistant at the Tobacco Substation for the season of 1930, formerly tobacco expert for province of Brandenburg, Germany.

${ }^{2}$ Berthold, Th.. Vergleichende morphologische und physiologische Untersuchungen an einigen Tabaksorten, Landw. Jahrbuch fuer Bayern Heft $11 / 12,1929$.
} 
earlier, to leave the same number of leaves if the stage of development of all plants is not entirely the same, because in carrying out this work only the stage of development of the single plant is decisive and not the number of leaves. An experienced grower does not count the leaves of the plant at topping, but tops according

Table 33. Yield of Plots Variously Topped and Suchered. Weight (Grams) of Green and Cured Leaves

Treatment

\section{Early}

High-topped and suckered ... High-topped and not suckered Low-topped and suckered ...

Low-topped and not suckered 183

\section{Late}

High-topped and suckered ... 261

High-topped and not suckered 259

Low-topped and suckered ... 222

Low-topped and not suckered 219

Only suckered ............ 234

Untreated ............. 233

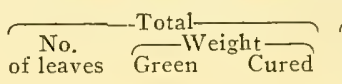

No. Yield per plant
of leaves
Green

to his judgment of the stage of development and to the growth ability of the plant.

"High-topping" means that as many leaves were left on the plant as could be expected to develop into commercial grades. This was two or three leaves below the first bald sucker (spike sucker). "Low-topping" means that the stalk was broken off about three leaves below "high-topping."

In the investigation of the root systems the absolute and relative size of the main laterals and (smaller) fibrous roots was compared in the following ways: (1) A few plants that had about the average yield of leaf for thit particular treatment, were compared with plants that had average leaf yield for every other treatment. (2) From each plot, roots of all the plants that produced about the weight of leaves that was average for all plots combined, were compared. (3) The differeatly treated early topped plots were first compared among themselves, as were the late topped. Then the early topped plots were compared with the late topped, and finally with the untopped plants.

The root system of the Havana Seed type is very similar to that of the types that I studied in Germany, with the exception of the type Schwabacher Veilchentabak F. D., Nicotiana rustica. The Havana Seed root system consists of larger laterals and smaller fibrous roots, most of which spread out horizontally. A chief, or tap, root was not found, but repeatedly rudiments only. The biggest part of the fibre roots is mostly around the crown. 


\section{Comparison of the Plants With the Average Yield of Leaf of Each Treatment}

The root system of the early topped, suckered plants was on the average somewhat bigger than that of the topped, not suckered plants. The difference depended partly on the quantity of the fibrous roots, partly on the thickness of the main laterals. The formation of root of the early and high-topped, suckered plants was almost as large as that of the early and low-topped, suckered
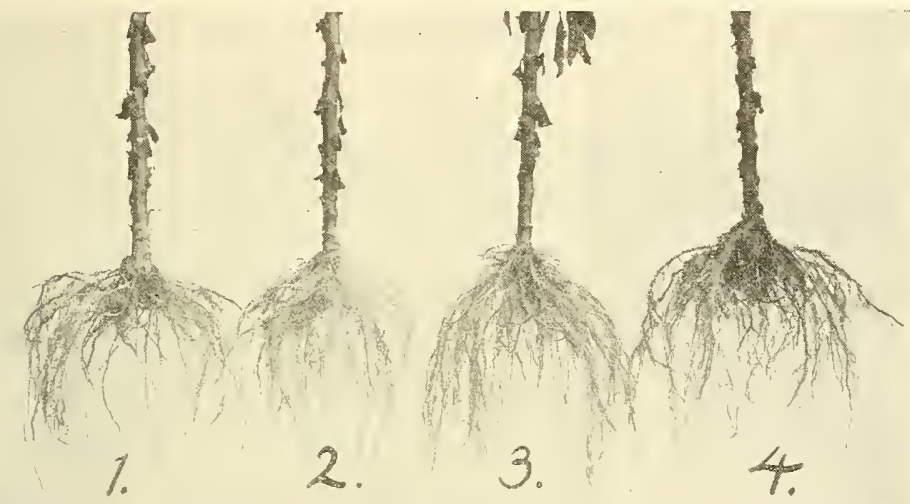

FIgURE 23. Effect of topping and suckering on root development. No. 1, untreated; 2 , only suckered; 3 , only topped; 4 , topped and suckered.

plants. In general the root system of the plants not suckered (with the exception of Plot $3 \mathrm{~b}$, untreated) was very well perfected. Sometimes that of the early and low-topped, not suckered plants was better developed than that of the high-topped, not suckered plants and just as large as that of the topped, suckered plants. The differences were certainly not very large.

Between the late topped, suckered and not suckered plants there was not such a large difference. The root development of plants of this series was generally not so vigorous as that of the early topped plants. Between the early and high-topped, not suckered and the late and high-topped, not suckered plants there was no considerable difference. In comparison to the topped plants the root system of the not topped ones was considerably smaller. The roots, especially the main laterals, were not so thick and not so long as those of the topped plants. The mat of fibrous roots was not so close. Contrasted with the topped, the root system of the not topped plants appeared very poor in development.

No great difference in the size and perfection of the root system between the untreated and the plants only suckered could be found. 


\section{Comparison of the Plants With the Average of Yield of All Plants}

The early and high-topped, suckered plants had a somewhat larger root system than the early and high-topped, not suckered plants. The root systems were all very well developed, however, with the difference that in general the suckered had more fibre roots, especially around the crown of the root, than the not suckered plants. The root system of the early and low-topped, suckered plants was a little bigger than that of the early and hightopped, not suckered, and that of the early and low-topped, not suckered was nearly as large as that of the early and high-topped, suckered plants. Also the root development of the early and lowtopped, suckered plants was better and a little bigger than those of the early and high-topped, not suckered plants. They had more fibre, and somewhat thicker main roots. From these results it may be inferred that low-topping had a bigger influence on the development of the root system than high-topping.

On the late topped plants the differences in the effect of the different treatments compared with the early topped plants were not so apparent. This was probably due to the drought and duration of the time after topping. From the plants of Series II, the low-topped, suckered have the best perfected root system, then the high-topped, suckered plants are next. Between the low and hightopped, not suckered plants the difference is insignificant.

Compared with the early topped, the root system of the late topped plants was in general not so well perfected. The root system of the early and low-topped, suckered plants was a little better developed, and had more fibre roots than that of the late and low-topped suckered plants. The early and late high-topped, suckered plants did not differ perceptibly.

The root systems of the not-topped, suckered plants and untreated plants were much the same, but rarely as big as that of a topped plant.

A direct relation between yield of leaf and size of the root system was not established. It may be regarded, however, as self-evident that a certain connection exists between the aerial and subterranean parts of the plant. As a rule, the plants producing bigger yield of leaf have a larger root system, yet, the comparison certainly showed in respect to the harvested weight of leaf that the root system of the early and low-topped, not suckered plants is considerably bigger than that of the untreated plants, although the yield of leaf of the latter is bigger than that of the former. Similar relations exist between the root system of the early and low-topped, not suckered plants and that of the late and high-topped, not suckered plants, and that of the early and low-topped, suckered with that of the early and high-topped, suckered plants. 
Thus from this investigation we find that topping and suckering promoted the perfection of the root system, besides aiding growth of the leaves, and the effect of topping on the development of the root system was bigger than that of suckering. Suckering effected chiefly only a better development of the net of fibre roots. Final conclusions about the extent of the effect of topping and suckering can, however, not be drawn from this test. Because of the drought after topping, the whole development of the plants

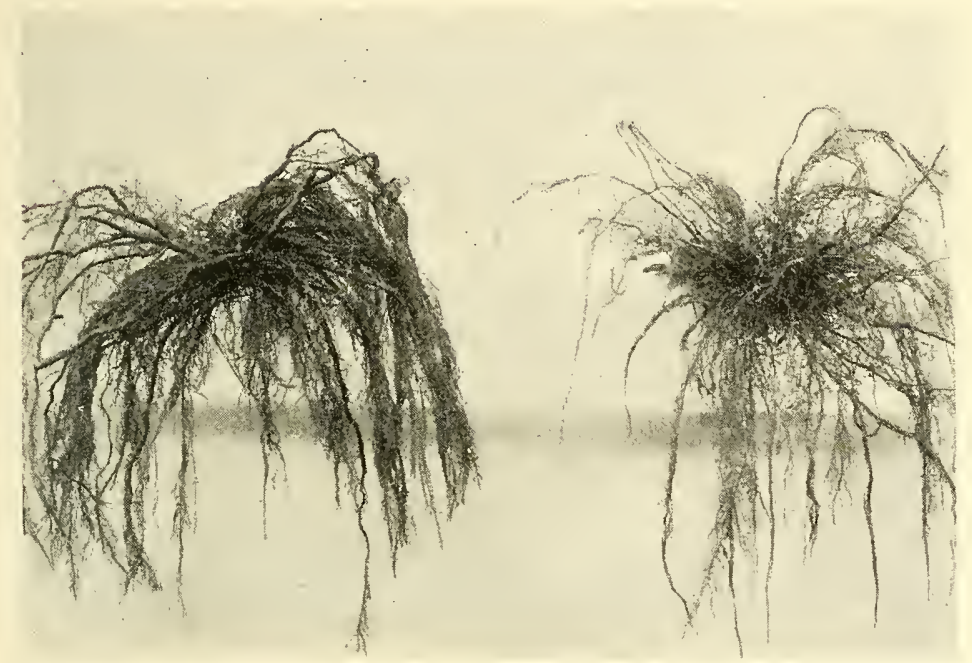

Figure 24. Root systems of plants differently treated. Left, topped and suckered. Right, neither topped nor suckered. Both plants were transplanted on May 31, and taken out of the soil on September 6. Plant on left topped very low on July 8.

was reduced. It may be accepted, however, that the perfection of the root system is largely affected by the height of topping, the stage of development of the plant at topping time, and the duration of time after topping. See Figure 24.

The big difference in the size of the root system between topped, suckered and untreated plants shows that the range of root development and, therefore, the ability to collect larger quantities of food and water are increased. Also the larger root system has a bracing value and keeps the plants from blowing over during storms.

\section{The Development of the Leaves}

Besides the effect on the growth, topping and suckering also had a considerable influence on the maturity of the leaves. The leaves of topped, suckered plants grew better than those of untreated 
plants. The effect of the different methods of treatment on the maturity is analogous to the development of leaf. It was found that topping as well as removing the suckers accelerated the ripening of the leaves. Accordingly the leaves of the early topped plants began to ripen earlier than those of the late topped plants. On the leaves of the low-topped plants the first spots of maturity showed themselves soon after topping. The ripeness of the early and low-topped suckered plants was, therefore, far advanced when compared to the plants treated in any other way. At the harvest, they were overripe, while the early and high-topped suckered plants were not in this advanced stage of maturity. Leaving the suckers on the plants retarded the maturity of leaf, for the topped but not suckered plants came to maturity later than the topped and suckered plants. This observation was made on the early and on the late topped plants. From Series II the high-topped suckered plants also ripened later and more slowly than the lowtopped suckered plants.

The leaves, especially those from the upper part, of the untreated plants only suckered were still green at the middle of August and had few or no spots of maturity. The leaves of the not-topped plants ripened slowly from the lower ones upward. Yet more sandleaves could be harvested from these plants than from the topped ones.

Nelson ${ }^{1}$ found in his researches on the effect of topping and suckering on the quality that low-topping yields more light colored leaves than high-topping. The reason for this result may be the greater influence of low-topping on the maturity, for usually riper leaves get a lighter color in curing.

The treatment of the plant also influences, in different degree, the quality and constitution of leaf. Even by touch, it could be established that the leaves of the low-topped, suckered plants had a much rougher structure and were thicker than those of the hightopped, suckered plants. Concerning the effect of topping Garner ${ }^{2}$ states that high-topping retards the maturity and produces thinner leaves.

\section{Growth of the Suckers}

In the intensity of the production of suckers the high and lowtopped plants showed no large difference. The lateral shoots of the high-topped, not suckered plants were a little higher but not stronger than those of the low-toppped, not suckered plants. At the time of harvest the suckers of the early topped plants had flowers, whereas those of the late topped, not suckered plants were

\footnotetext{
${ }^{1}$ Nelson, N. T. The effect of topping and suckering on Havana Seed Tobacco. Conn. Agr. Exp. Sta. Bull. 297. 1928. 1929.

${ }_{2}^{2}$ Garner, W. W., Tobacco Culture, U. S. Dept. Agr. Farmers' Bull. 571.
} 
backward in their development because of the later topping. On the suckered only and still more on the untreated plants the growth of suckers was small.

\section{Turgescence of the Leaves}

Further, there was observed an influence of topping and suckering on the turgescence of the leaves. Especially on hot days the leaves of the differently treated plants exhibited different degrees of wilting, which was certainly caused only by topping and suckering. The leaves of the untreated plants wilted most and those of the low-topped suckered plants wilted least. The leaves of the high-topped, not suckered plants had a less erect position of leaf than those of the high-topped, suckered plants. On the leaves of the early topped plants this difference came out a little more than on the late topped plants. The cause is probably this: By topping, a considerable reduction of the organs of evaporation takes place because the main shoot has been removed and the number of leaves decreased. With the same root pressure a higher turgor for the remaining leaves will be effected. In the same way, suckering increases the turgor. Besides other important factors, the height of topping is an influence, therefore the turgescence. On the leaves of the topped, suckered plants it is to be expected that with the increase in thickness of the leaves the turgescence is augmented; the same may also be remarked about the age of leaf. Undoubtedly the size of the root system plays an important rôle here too.

From the observations and investigations described it can be seen that topping especially produced a better growth of the whole plant and changes the course of development of the leaves. The extent of the effect of topping depends upon the conditions of growth, the ability of development of the type and upon the stage of development of the plant at topping and the height of topping. For correct topping the plant must be in that stage of development in which the ability of growth is fully apparent and consideration must be taken of the character of soil, fertilization and circumstances of weather that the plant must still endure. In regard to the marked effect of topping on the development of the plant, therefore, Hoffmann" rightly says: "Das Entgipfeln darf als eine der einflussreichsten Massnahmen im Tabakbau bezeichnet werden." (Topping may be regarded as one of the most important measures in the tobacco industry.)

${ }^{1}$ Hoffmann, Oek. Rat, Anleitung zum Tabakbau, 1919. 


\section{INFLUENCE OF PLANT TRIMMING ON WEIGHT OF THE SEEDS}

TH. BERTHOLD

One of the factors to be considered in the production of a good crop of tobacco is good seed. Although this is generally recognized and practiced in the growing of other crops, it has never received much attention in tobacco production. One reason is the enormous number of seeds that is produced by one plant; only a few plants are needed to produce seed enough for a large field. The quantity required is not sufficient therefore to encourage commercial seedsmen to grow and improve the strains by selection and breeding.

Shamel $^{1}$ and Shamel and Cobey ${ }^{2}$ found that the weight of the seed is important. Heavy seed produced more vigorous, larger and more uniform plants than did light seed. They also state that plants from such seed are more resistant to disease. They suggested that these benefits were due to the increased reserves of food in the heavier seed.

Selby ${ }^{3}$ and Hoffman ${ }^{4}$ investigated the influence on seed development when the inflorescence is trimmed and more leaves are retained. The object of the tests to be described here was to determine what effect different practices, such as removal of leaves and trimming the inflorescences down to certain number of pods, would have on the weight and number of seeds produced. The tests were conducted on Havana seed tobacco at the Tobacco Substation in Windsor.

On the first row all pods except 10 to 11 of the earliest and largest were trimmed off. On the next row 20 to 25 were left; next row, 35 to 40 ; the last row was not trimmed at all. Sixty plants were in each row. At the time of harvesting the leaves, all the leaves were removed from half of each row; on the other half the three top leaves were left. All suckers and flowers that developed after harvesting the leaves were removed. The extremely dry weather during the latter part of July and during the month of August was not favorable for seed development.

The first seed was harvested on September 5, at which time the pods and pedicles of the plants trimmed to 10 to 11 pods and those to 20 to 25 , were entirely brown and dry. On those with 35 to 40 pods the outer ones were still green, while on the untreated plants, almost all were green. Some pods from all plots except the untreated row (where they were too green) were removed at that time. Also eight plants from every row were cut off at the sur-

\footnotetext{
${ }^{1}$ Shamel. A. D. The improvement of tobacco by breeding and selection. Yearbook U. S. Dept. Agr. 1904.

${ }^{2}$ Shamel, A. D., and Cobey, W. W. Tobacco breeding. U. S. Dept. Agr. Bull. 96. 1907.

${ }^{3}$ Selby, A. D., and Houser, True. Tobacco: Breeding cigar filler in Ohio. Ohio Agr. Exp. Sta. Bull. 239. 1912.

${ }^{4}$ Hoffman, Oek. Rat. Anleitung zum Tabakbau, 1919.
} 
face of the ground and were hung in a tobacco barn to test the effect of after-ripening in this condition.

On September 23 and 24, pods were again harvested from each row and eight more plants from each were cut and hung in the shed.
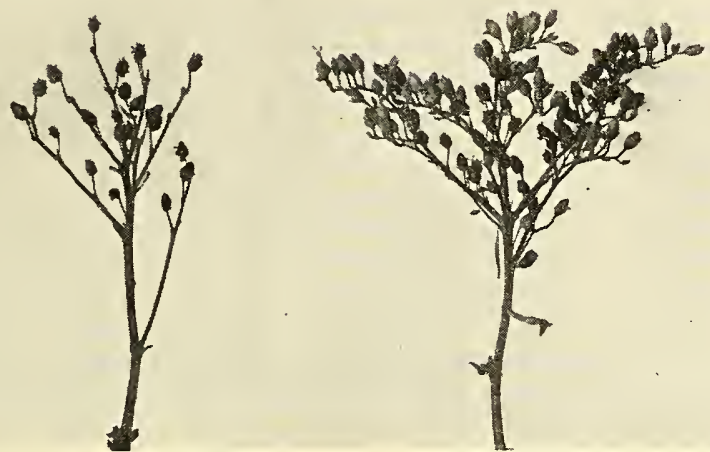

Figure 25. Trimmed (left) and untreated (right) inflorescences.

After the harvested pods were thoroughly dried, the seed was threshed. In order to determine the influence of any treatment on the weight of seed, one-fourth of a gram was weighed and the number of seeds counted. The results of these counts are shown in Table 34.

Table 34. Influence of Plant Trimming on Weight of Seeds Harvested September 5

Method of treatment

Inflorescence with $10-11$ pods, plants with leaves ......

\begin{tabular}{|c|c|c|}
\hline$z^{\prime \prime}$ & " & $20-25$ \\
\hline "6 & “ & \\
\hline$"$ & " & $35-40$ \\
\hline " & $" 6$ & " \\
\hline " " & & " \\
\hline
\end{tabular}

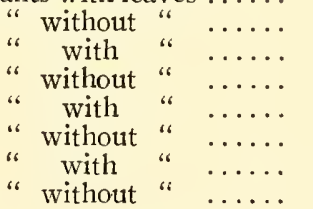

$\begin{array}{cc}\begin{array}{c}\text { No. of } \\ \text { seeds } \\ \text { in 1 gm. }\end{array} & \begin{array}{c}\text { Weight } \\ (\mathrm{gms} .) \text { of } \\ 10,000 \text { seeds }\end{array} \\ 11,636 & 0.859 \\ 11,772 & 0.849 \\ 11,800 & 0.847 \\ 12,092 & 0.827 \\ 12,856 & 0.778 \\ 12,148 & 0.823 \\ 13,832 & 0.723 \\ 15,084 & 0.659\end{array}$

Harvested September 23-24

Inflorescence with 10-11 pods, plants with leaves ......

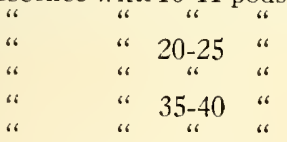

" Not trimmed "

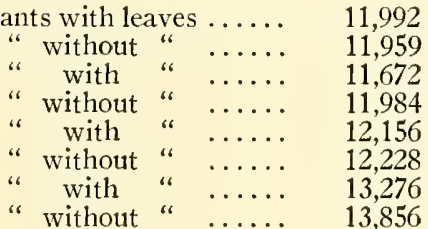


These figures show in general that the weight of the seeds is increased by reducing the number of pods per inflorescence. This difference is most evident when we compare the weight of seeds from inflorescences that were not trimmed at all and those that were trimmed to a smaller number of pods. This was due to the much larger number of pods on the untrimmed plants. The average number of pods on an untreated plant was 110, as determined by counting 10 plants.

Permitting some of the upper leaves to remain on the stalk until the pods were ripe also had a favorable influence in increasing the weight of the seeds. This was more apparent when comparing the untrimmed plants with the others, because in this case almost the entire ripening period of the pods was after the harvesting of the leaves.

\section{After-Ripening}

Kissling $^{1}$ states that if the stalks of the seed plants are taken from the field with the inflorescence and left to dry out gradually in the shed, there will be a considerable increase in the weight of the seed. It was with the object of determining to what extent this was true that eight plants from each treatment were removed and dried in the shed as previously mentioned. Seeds from these plants were counted in the same manner as before described and the results are presented in Table 35.

Table 35. Weight of Seeds from Plants Dried Oút in Shed Harvested September 5

Method of treatment

Inflorescence with $10-11$ pods, plants with leaves .

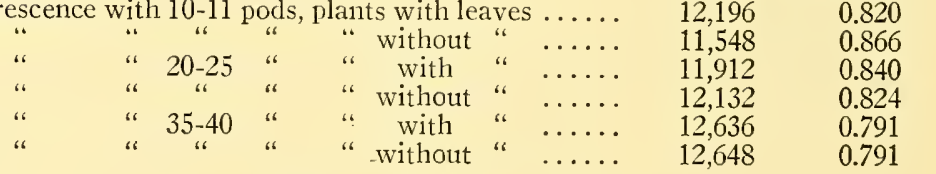

Harvested September 24

Inflorescence with 10 -11 pods, plants with leaves .... $\quad 11,416 \quad 0.876$

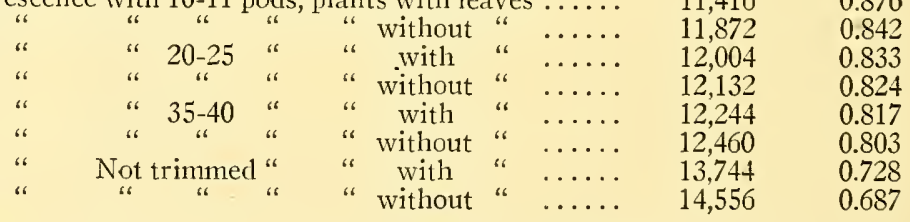

This table shows again the favorable infuence on seed weight of trimming the inflorescences and of leaving the top leaves on the seed plants.

\footnotetext{
${ }^{1}$ Kissling, R. Tabakkunde, Tabakbau and Tabakfabrikation, 1925.
} 
When Table 35 is compared with Table 34, however, there appear to be no significant differences to indicate that harvesting the seed in this manner has increased the weight of the seed. In this connection it should be mentioned that during the hot, dry season of 1930 the pods ripened more rapidly than usual, and when they were removed from the inflorescence in the field on the dates mentioned they were for the most part dry and brown, as also the pedicels that supported them. It may be supposed that increase in seed weight would be possible only if the pods and pedicels were not entirely mature when the plants were taken from the field.

\section{Influence of the Position of the Pod in the Inflorescence}

Since the pods of an inflorescence do not all develop at the same time and usually differ in size, the seeds from pods in different parts of the inflorescence were counted and weighed in order to see whether position has an influence on weight of seed. The results are presented in Table 36.

Table 36. Influence of Position of Pods in Inflorescence on the Weight of the SeEd

A. Pods of an untrimmed plant with leaves

$\begin{array}{cc}\text { No. of } & \begin{array}{c}\text { Weight } \\ \text { seedsin1 } \mathrm{gm} .\end{array} \\ 10,000 \text { seeds }\end{array}$

1. Pods from the inner part of the crown

Number of seeds ......... 2,142

Weight of seeds .......... $0.187 \mathrm{~g}$

11,455

0.873

2. Pods from the outer part of the crown

Number of seeds ........ 2,720

Weight of seeds ......... $0.204 \mathrm{~g}$.

3. Pods from the side branch beneath the crown

Number of seeds ........ 3,684

Weight of seeds ........... $0.307 \mathrm{~g}$.

$12,000 \quad 0.833$

B. Pods of an untrimmed plant without leaves

1. Pods from the inner part of the crown

Number of seeds ........ 2,575

Weight of seeds ......... $0.228 \mathrm{~g}$.

2. Pods from the outer part of the crown

Number of seeds ........ 3,334

Weight of seeds $\ldots \ldots \ldots \ldots .0 .138 \mathrm{~g}$.

3. Pods from the side branch beneath the crown

Number of seeds ........ 4,014

Weight of seeds ........... $0.301 \mathrm{~g}$.

The results on both plants $A$ and $B$ indicate that the heaviest seeds are found in the pods at the center of the inflorescence. These are the pods that are developed first. The seeds from the lateral branches below the main forks of the inflorescence are not quite so heavy. Lightest of all are the seeds from the outside of the main inflorescence, that is, those that are developed latest. 
Furthermore, the results show the influence of the leaves on the development of seed in different parts of the inflorescence. The removal of all leaves had no influence on the weight of seeds at the center of the inflorescence but a striking reduction in weight of the seed from the outer part appeared when the leaves were removed. These pods are developed mostly after leaf removal and do not obtain their full supply of food necessary to give seed of good weight.

Undoubtedly the increasing effect of dry weather played some part also in the development of these later pods, in just the same way that it reduces the size of leaves. Certainly the drought, which began during the latter part of July, had more effect on the younger pods than on the interior pods, which were already in an advanced stage of development. It seems likely that under unfavorable conditions of growth, the seed may be harvested prematurely. Therefore, in a dry season the best seed cannot be obtained from a sandy leachy soil and the grower should select his seed from less sandy fields where development may be completed.

In practice, the lighter seed is usually separated from the heavy by a cleaning or blowing apparatus.

Germination tests on the seed secured from the plants treated in different ways as mentioned above did not show any significant differences in the percentage of seed that sprouted. All germinated at about 80 per cent.

\section{Summary}

1. Trimming the inflorescence down to a smaller number of pods increases the weight of the seeds.

2. Leaving some of the upper leaves on the stalk until the pods are entirely mature increases the weight of the seeds.

3 . Pods in the center of the inflorescence produce heavier seeds. For production of heavy seeds about 20 to 25 of these should be left. All others should be trimmed off soon after the fading of the first flowers. 


\title{
CURING EXPERIMENTS
}

\author{
O. E. Street
}

In the summer of 1929, experiments on the curing of shade tobacco were started in two chambers especially designed for the exact control of temperature and humidity.

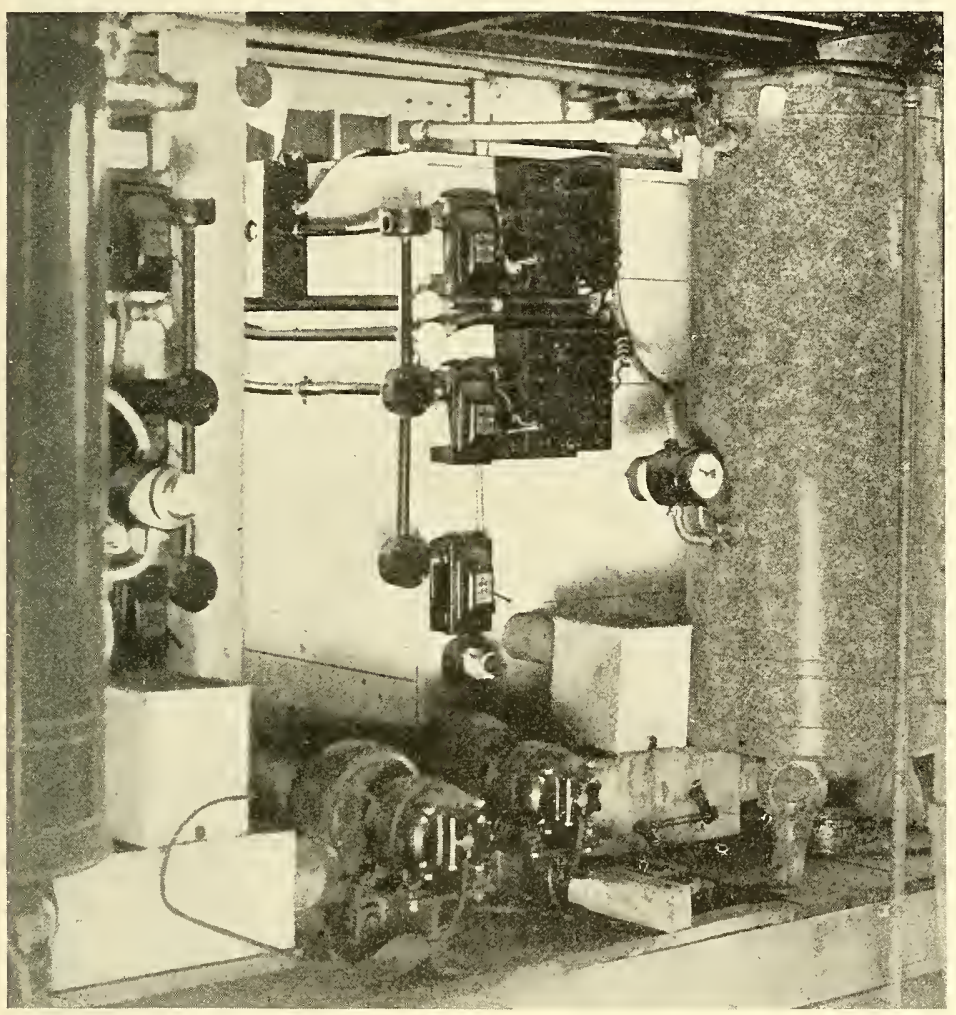

FIGURE 26. Rear view of curing chambers, showing instrument panels and other mechanical features.

The chambers are boxes of cubical shape, four feet in each dimension, built with double walls of wood and having double doors, the inner door being of glass sash. Each chamber holds 18 lath of shade leaves. Figure 26 shows the instrument panels of the two chambers, and other mechanical features. Figure 27 shows the interior of a chamber with tobacco and instruments in position. The design and construction of the chambers follows 


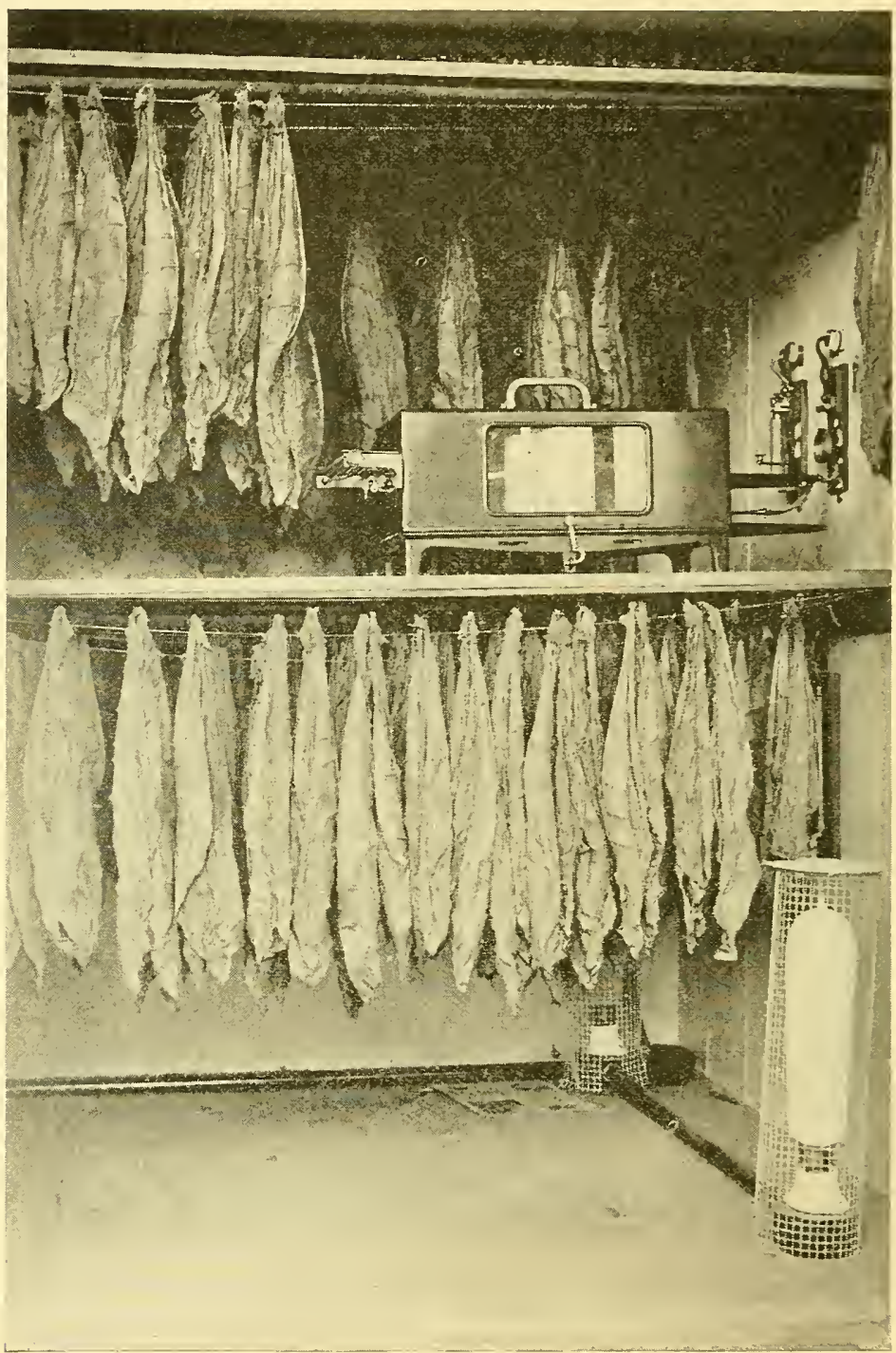

FIGURE 27. Interior of curing chamber.

closely those used by Johnson ${ }^{1}$ at the Wisconsin Agricultural Experiment Station, through whose courtesy the necessary electrical and mechanical specifications were available.

${ }^{1}$ Johnson, James. Constant temperature and humidity chambers, Phytopati 18: 227-239. 1928. 
The general plan of the experiments in 1929 was to study the effect of differences in humidity on the cure of tobacco, the temperature being kept nearly the same in the two chambers. Two runs were made under conditions to be detailed later, tobacco from the Station tent being used. The third run, after the hailstorm, was made on tobacco obtained through the courtesy of $\mathrm{H}$. C. Griswold of Windsor. A preliminary study of temperature effect was also made on this run.

In each of these tests, tobacco from the same basket was used for both chambers, alternate lath being taken for each chamber as the tobacco was strung. This was done to secure equal lots for the two chambers.

The following table gives in condensed form notes on the tobacco while curing and on the cured product.

\section{Table 37. Summary of Curing Results, 1929}

1 st run, 1st picking Station shade. Temperature $90^{\circ} \mathrm{F}$., both chambers

\author{
Description \\ of treatment

\section{Notes on tobacco in curing}

Chamber 1, 60-70\% humidity

Chamber 2, 85-97\% humidity
Cured in 6 days. Leaves tended to be brittle and boardy. Final color yellow-green, typical "haying down."

Cured in 9 days. Leaves pliable and of good texture. Final color medium to dark brown. Midribs cured slowly.

\author{
Notes on \\ sweated tobacco
}

Much too yellow, poor grain, no desirable brown leaves, stiff and boardy. Inferior aroma and bitter taste.

Very good grain, leaves elastic and of good quality. Color a medium brown. Mild aroma and pleasant taste.

$2 \mathrm{~d}$ run, $3 \mathrm{~d}$ picking Station shade. Temperature chamber $1,90^{\circ}$, chamber $2,94^{\circ} \mathrm{F}$.

Chamber $1,70-80 \%$ Cured in 15 days. Much humidity

Chamber 2, 85-95\% Cured in 16 days. Cure humidity improved cure over 60 $70 \%$ humidity. Final color light brown, uniform, with a slight green cast. Good texture.

slow in early stages, very rapid in latter stages. Color range brown to reddish brown. Leaves a little papery.
Good color and texture. Leaves elastic and free from coarseness. Color light brown, uniform.

Tobacco not very satisfactory, rather inelastic. Color a dark olive but quite uniform.

3d run, 3d picking (2d seconds), Griswold plantation. Humidity 80-90\%, both chambers.

Chamber $1,85^{\circ} \mathrm{F}$. Cured in 15 days. Color mostly light brown, no greenish or olive shades. Leaves had some hail injury, did not cure uni-

Colors quite satisfactory, mostly medium to dark brown, fairly uniform. No olive shades. 
Table 37. Summary of Curing Results, 1929-Concluded. $3 \mathrm{~d}$ run, $3 \mathrm{~d}$ picking ( $2 \mathrm{~d}$ seconds), Griswold plantation. Humidity $80-90 \%$, both chambers--Concluded.

Description of treatment

Chamber $2,95^{\circ} \mathrm{F}$. Cured in 10 days. Color medium to dark brown, with some olive shades. Leaves somewhat injured by hail. Cure very rapid for this picking.
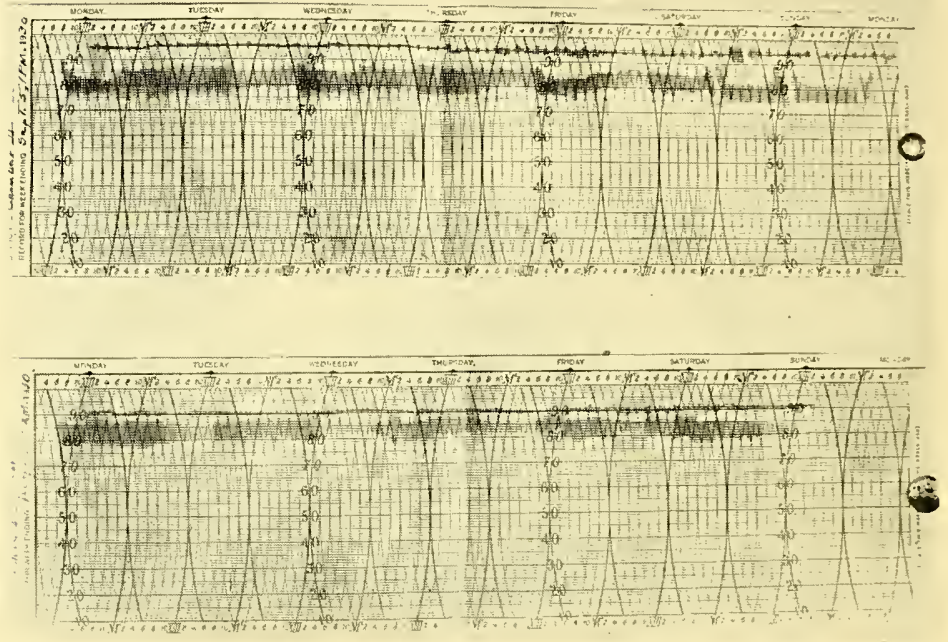

FIGURE 28. Hygrothermograph charts showing temperature and humidity control in curing chambers.

Although the control during these runs was not so good as was obtained later, it was possible to make some general observations from the results.

A relative humidity of 60 to 70 per cent dried out the tobacco too rapidly, setting the green color and interfering with normal curing processes. These undesirable characteristics were not eliminated in subsequent sweating and a rank, coarse leaf was the final result.

Too high a humidity, 90 per cent or above, should also be avoided, especially on later pickings. Aside from the danger of pole sweat, which is very important in shed curing, the cure is delayed too much and the leaves are apt to be spotted. A humidity of $80-85$ per cent seems to be the optimum. 
From the evidence of the third run there is partial proof that a temperature of $95^{\circ} \mathrm{F}$. is too high for the later pickings; $85^{\circ}$ was considerably better.

\section{Experiments in 1930}

Based on the above results, an optimum humidity of 80 to 85 per cent was chosen for the experiments in 1930. This was maintained in both chambers through four runs, while the temperature was varied through a range of 80 to $95^{\circ} \mathrm{F}$. As far as possible, the various temperatures were tested on both early and later pickings. Control of both temperature and humidity was improved over that of the previous year. Figure 28 shows some typical charts from the hygrothermograph records. The broader band in each case indicates the range in relative humidity, and the narrower band the range in temperature.

In addition to the tobacco cured in the control chambers, a few laths from each lot were hung in a large well-ventilated curing room in the Station building, where they were allowed to cure in ordinary atmospheric conditions to serve as a check.

The following table shows the characteristics of the tobacco in curing and after sweating.

\section{Table 38. Summary of Curing Results, 1930}

Description of

at $80-85 \%$ humidity

$$
\begin{gathered}
\text { Notes on } \\
\text { tobacco while curing }
\end{gathered}
$$

Notes on

sweated tobacco

1st run, 1st picking, Station shade

Chamber $180^{\circ} \mathrm{F}$. Cured in 9 days. Some pole sweat noted. Final color medium brown to chacolate brown. Slow cure for 1st picking.

Chamber $295^{\circ} \mathrm{F}$. Cured in 7 days. Tobacco in brown stage in 4 days. Final color olive green. Rapid cure but apparently satisfactory.

Pole sweat spread badly in case during sweating. Reddish brown color very pronounced. Tobacco only fair.

Tobacco much superior to that of chamber 1. Color a light olive brown, very good.

$2 \mathrm{~d}$ run, 2d picking, Station shade

Chamber $180^{\circ} \mathrm{F}$. Cured in 13 days. Final color reddish brown, not very dark, very mottled and many yellow spots. Secondary veins cured more rapidly than web.

Chamber $295^{\circ} \mathrm{F}$. Cured in 11 days. Web cured rapidly, midribs slowly. Final color a desirable medium brown, uniform.

A little pole sweat. Reddish shades a little deeper. Tobacco somewhat better than first run in this chamber.

Tobacco very good. Olive tinge a little less pronounced. Very good texture and elasticity. 
Table 38. Summary of Curing Results, 1930-Concluded

Description of

treatment. All runs

at $80-85 \%$ humidity

3d run, 4th picking, Station shade

Chamber $185^{\circ} \mathrm{F}$. Cured in 18 days. Type Some pole sweat. General of cure similar to $80^{\circ} \mathrm{F}$. Final color dark reddish brown, not very uniform.

Chamber $290^{\circ} \mathrm{F}$. Cured in 14 days. More rapid water loss than at $85^{\circ}$. Greater development of olive brown color. Uniformity good.
Notes on sweated tobacco color a dark red. Not so good as Chamber 2.

Colors lighter than inchamber 1. Deep chocolate browns, rather good for 4th picking.

4th run, 3 1-2 picking, Hartman plantation late shade

Chamber $180^{\circ} \mathrm{F}$. Cured in 22 days. Curing Color reddish brown and proceeded slowly at all stages, bright yellow stage prominent. Final color dark reddish brown.

none whatever of the olive shades. Very marked difference in color in favor of this chamber.

Chamber $295^{\circ} \mathrm{F}$. Cured in 12 days. Allowed Brokes due to handling to run 10 days longer to dry out midribs. Web brown in 11 days. Final color was toward a greenish brown. while too dry. Dark colors, very objectionable, of the "blue-black" type, were very common.

The tobacco was sorted into the usual grades for shade, the records for the checks on the third and fourth runs being included. Checks for the first and second run did not differ enough from the low temperature lots to justify inclusion in the table. The table of sorting records follows:

TABle 39. Sorting Record, 1930

Treatment

1st run, 1st picking

Chamber 1

Chamber 2

$2 d$ run, $2 d$ picking

Chamber 1

Chamber 2

$3 d$ run, 4th picking

Chamber 1

Chamber 2

Check on $3 \mathrm{~d}$ run

Temp. $70^{\circ} \mathrm{F}$, Hum. $80 \%$

4th run, $31 / 2$ picking

Hartman plantation

Chamber 1

Chamber 2

Check on 4th run.

Conditions same as check on run 3 .

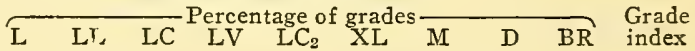

$\begin{array}{lllllllll}22.6 & 20.0 & 21.3 & 7.4 & 9.3 & 0.0 & 0.0 & 19.4 & 2.708\end{array}$

$\begin{array}{lllllllll}21.8 & 19.7 & 27.6 & 13.8 & 5.3 & 7.2 & 4.6 & 3.181\end{array}$

$\begin{array}{llllllll}18.4 & 22.7 & 30.2 & 6.0 & 12.4 & 3.8 & 6.5 & 2.919\end{array}$

$\begin{array}{llllllll}22.2 & 21.2 & 25.1 & 13.4 & 3.1 & 12.4 & 2.6 & 3.178\end{array}$

$\begin{array}{rrrrrrrrrr} & 3.4 & 30.2 & 3.4 & 4.2 & 5.9 & 6.7 & 34.4 & 11.8 & 1.533 \\ 4.8 & 9.6 & 25.7 & 9.6 & 1.2 & 8.4 & 16.1 & 21.7 & 2.8 & 2.847 \\ & & & & & & & & & \\ & & 22.8 & 3.6 & 2.1 & 5.2 & 12.4 & 52.4 & 1.5 & 1.271 \\ & & & & & & & & & \\ 2.4 & 15.6 & 26.9 & 2.8 & & 6.6 & 39.1 & 6.6 & & 2.195 \\ & 1.0 & 14.6 & 2.4 & 5.3 & 3.9 & 5.8 & 39.8 & 28.2 & .972\end{array}$

$\begin{array}{llllllll}8.5 & 38.6 & 1.4 & 2.9 & 18.5 & 21.4 & 8.5 & 1.906\end{array}$ 
From the sorting records, additional evidence on the effect of temperature on the color of cured tobacco may be found. No LV's are found at $80^{\circ}$, either first or second picking, while more than 13 per cent are found in each of the corresponding $95^{\circ}$ runs. The grade indexes are almost identical for the two $95^{\circ}$ lots, both better than the indexes for the $80^{\circ}$ lots. The darker color at the lower temperature in the second run, is shown by the presence of M's.

In the third rum, as the temperature was increased the colors became lighter. In the check at about $70^{\circ}$, there was 52.4 per cent darks, with 34.4 per cent at $85^{\circ}$ and 21.7 per cent at $90^{\circ}$. L's and LL's made up 14.4 per cent of the total at the higher controlled temperature, 3.4 per cent at the lower, and none in the check. More LV's and M's were also found in the $90^{\circ}$ lot.

The most striking feature of the fourth run was the large development of deep olive colors at a temperature of $95^{\circ}$. In contrast with fourth picking tobacco at all lower temperatures, in which the darks were of a reddish tinge, there was a great preponderance of "blue-black" leaves. Apparently the very high temperature caused too rapid drying and interference with normal removal of the decomposition products, resulting in an excess of nitrogenous compounds which blackened in the sweating process.

It may be noted in this run that there was 39.8 per cent darks and 5.8 per cent mediums in the $95^{\circ}$ lots, and 6.6 per cent darks and 39.1 per cent mediums at $80^{\circ}$. Only 1.0 per cent L's and LL's at the high temperature can be contrasted with 18.0 per cent L's and LL's at the low temperature.

\section{General Discussion}

Curing of tobacco has been recognized for some time as the interaction of two separate processes. One of these is the dehydration of the leaf, the loss of water from the cells to the outside air. At saturation, or 100 per cent relative humidity, no loss occurs, but the rate increases in proportion as the surrounding air becomes less humid. The other process is the chemical breakdown of a certain portion of the leaf material, a process that removes all sugars and starches from the curing leaf, and a considerable part . of the simpler nitrogenous compounds.

It is necessary to maintain conditions in curing that permit these two processes to operate at about the same rate. This is best done by avoiding extreme conditions, as hot and dry or cold and moist combinations. Thus in the experiments of 1929, using temperatures near $90^{\circ} \mathrm{F}$. humidity conditions below 70 per cent hastened the drying too much, and did not permit normal chemical breakdown. A humidity above 90 per cent, at temperature below $85^{\circ} \mathrm{F}$, would cause pole sweat, but even at high temperatures, this very high humidity has ill effects. Drying out of the leaves is hampered 
and the chemical processes are allowed to advance too far, which causes a papery leaf. The use of 80 to 85 per cent relative humidity as a working standard for temperatures of $85^{\circ}$ to $95^{\circ} \mathrm{F}$. seems to be justified. At temperatures of $70^{\circ}$ to $80^{\circ} \mathrm{F}$. a humidity between 70 per cent and 80 per cent should maintain the proper balance between the two processes.

The effect of temperature, aside from its interaction with humidity, seems to be a fundamental one in the curing of tobacco. In the 1930 experiments, all at a humidity of 80 to 85 per cent, temperatures of $85^{\circ}$ and below consistently produced reddish brown tobacco after sweating, while temperatures of $90^{\circ}$ and above produced olive or greenish shades of brown. For the early pickings the higher temperatures were the most desirable, while for late pickings, too high a temperature was decidedly unfavorable.

A great difference in the appearance of the leaves while curing was noted. At $90^{\circ}$ and $95^{\circ} \mathrm{F}$. the web of the leaf dried out rapidly, leaving the midrib thick and fleshy. This would indicate that the web underwent curing and dried out before the system consisting of midrib and secondary veins was able to remove the products of chemical decomposition. At lower temperatures, notably at $80^{\circ} \mathrm{F}$, the process was almost completely reversed. The drying out was so retarded that the midribs and secondary veins completely cured while portions of the web remained green. These areas of leaf tissue, completely isolated and having no connection with the conducting system of the leaf, finally became yellow, but the cured leaf lacked uniformity of color.

While the amount of grain in the leaf was not determined with any degree of accuracy, it seemed more prominent in the tobacco cured at lower temperatures.

\section{Conclusions}

1. Relative humidities of below 70 per cent and above 90 per cent are inadvisable without regard to temperature.

2. Relative humidities of 80 to 85 per cent are the best for most conditions.

3. A temperature of $95^{\circ}$, with a relative humidity of 80 to 85 per cent, is the best for early pickings, while $85^{\circ}$ to $90^{\circ} \mathrm{F}$. seems better for fourth picking:

4. Tobacco cured at $85^{\circ} \mathrm{F}$., or below, had a reddish brown color and above $85^{\circ} \mathrm{F}$. various shades of olive-brown, depending on the picking.

5. "Blue-black" tobacco was produced by a temperature of $95^{\circ} \mathrm{F}$., 80 to 85 per cent humidity, on fourth picking tobacco.

6. Higher temperatures produce more uniform colors and lower temperatures a more prominent grain. 


\title{
TOBACCO INSECT STUDIES IN 1930
}

\author{
DONALD S. LACROIX ${ }^{1}$
}

The work upon which this report is based includes three separate phases: a survey of insects that attack tobacco, a series of insecticide tests, and miscellaneous observations. The work was made possible through the coöperation of Dr. Anderson and his associates at the Tobacco Substation in Windsor.

\section{Survey of Tobacco Insects}

In order to obtain a comprehensive idea of the insect abundance and listribution throughout the tobacco growing districts in Connecticut, tobacco plantations were visited in the following places: Avon, Bloomfield, Buckland, Burnside, East Granby, East Hartford, East Windsor, East Windsor Hill, Enfield, Granby, Hazardville, Manchester, New Milford, Poquonock, Rainbow, Silver Lane, Simsbury, South Windsor, Suffield, West Granby, West Suffield, Windsor, Windsor Locks, and Windsorville. The results of this survey are reported herein.

The season of 1930 was marked at the very outset by serious injury to newly transplanted tobacco by the seed corn maggot, Hylemyia cilicura Rond., and by wireworms, Limonius agonus Say. The wireworms alone infested about 50 per cent of the tobacco acreage in Connecticut. The maggot infestation was widespread, but much of the injury caused by this insect was attributed by many growers to wireworms, hence the difficulty in making an accurate estimate of its damage.

In most cases the activities of these two insects necessitated a second transplanting, and in not a few instances a third. From these facts it is only too obvious that these pests cannot be allowed to go unnoticed. Tobacco set out after about June 10 suffered no injury from either of the above-mentioned insects. Although this fact may suggest delayed planting as one avenue of escape, it is impractical, for most growers prefer to set out their plants as early as possible in order to have the tobacco cured during the hot weather of late summer.

Throughout the season the potato flea beetle, Epitrix cucumeris Harris, appeared on Havana Seed and shade grown tobacco, but caused its most serious injury in late July. This insect was found in practically every field of Havana Seed and shade grown tobacco visited and on a few Broadleaf plantations. Twenty-five to 30 per cent of the acreage suffered material losses from the attacks of this pest.

${ }^{1}$ Assistant Entomologist assigned by the Department of Entomology to the Tobacco Substation for the season of 1930. 
Next in importance are the grasshoppers, several species of which feed on tobacco, and all of which combined are of economic significance. These were particularly abundant on fields located near hay land or on fields planted on ground that had been in hay the year before. The red-legged grasshopper, Melanoplus femur-rubrum DeG., was responsible for considerable injury. Associated with it, but far less abundant, was the Carolina grasshopper, Dissosteira carolina Linn. Several other species, particularly the green grasshoppers or Locustidae, were found, and often accompanied the two above mentioned.

Hornworms or greenworms were not plentiful this season. A few were found here and there, pretty well distributed over the

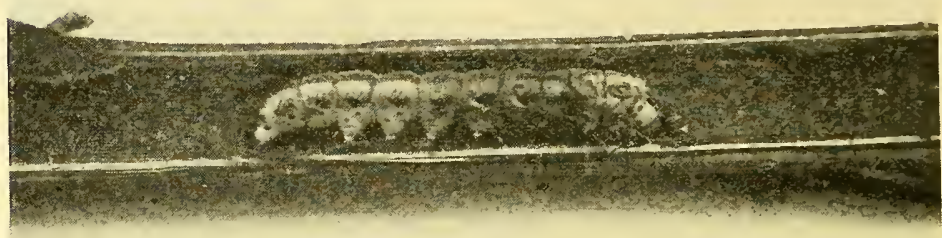

Figure 29. Stalk borer and its work.

tobacco growing area. They caused more injury in the New Milford district than in the Connecticut Valley. Both species, the northern, Protoparce quinquemaculata Haw., and P. sexta Johanssen were found, the latter being more abundant at the Tobacco Substation than the former.

Cutworm injury to newly set plants was found here and there, but most of the tobacco growers held the pest in check by the early use of poisoned bran bait, so that serious infestation had no opportunity to develop.

The stalk borer (Figure 29), Papaipema nitela Guen., was found in tobacco plants at East Hartford and at Windsor, tunnelling stalks near the edges of the fields. Its injury to tobacco was not widespread in 1930 .

The tarnished plant bug, Lygus pratensis Linn., was found in the majority of fields visited (except shade) in July and August. 
Although it was observed piercing immature flower buds, no injury was found that could have been attributed to it.

Many other species were taken on tobacco, but all were of minor importance economically.

\section{Experiments with Insecticides}

The potato flea beetle was present in the majority of fields and in many places seriously injured the foliage. Several materials were used in an attempt to find an insecticide that would control the beetle on tobacco, all of these being applied in the dust form. Three plots were screened off with tent cloth under shade and three plots were treated on sun grown tobacco.

Dusts were applied on the following dates: June 12, 19 and 23 and july $2,9,11$ and 16 .

\section{Paris Green and Calcium Arsenate}

This combination is said to be of value in controlling the southern species of flea beetle. When mixed at a rate of 1 part of paris green to 5 parts of calcium arsenate and applied at a rate of about 10 pounds to the acre on young plants, the beetle was somewhat checked (see Table 40). However, as the plants

Table 40. Flea Beetle Population on Dusted and Check Plots

\section{Sun grown tobacco}

\begin{tabular}{|c|c|c|c|c|c|c|c|}
\hline Date & $\begin{array}{l}\mathrm{Pa} \\
\text { and cal } \\
\text { Full stre }\end{array}$ & $\begin{array}{l}\text { isenate } \\
\text { Diluted }\end{array}$ & $\overbrace{\text { Full stre }} \mathrm{C}$ & Diluted & $\begin{array}{l}\text { Bariu } \\
\text { Full str }\end{array}$ & $\begin{array}{l}\text { ilicate } \\
\text { Diluted }\end{array}$ & Chec \\
\hline June 21 & 1 & 7 & 3 & 6 & & & 39 \\
\hline June 23 & 5 & 8 & 8 & 15 & 5 & 7 & 4 \\
\hline June 24 & 3 & 4 & 8 & 4 & 2 & 2 & 3 \\
\hline June 25 & 1 & 0 & 6 & 0 & 1 & 9 & 8 \\
\hline June 30 & 4 & 5 & 1 & 1 & 6 & 6 & \\
\hline July 7 & 14 & 8 & 6 & 6 & 5 & 6 & \\
\hline July 12 & 85 & 29 & 6 & 24 & 2 & 13 & 27 \\
\hline & & & lade grc & tobacco & & & \\
\hline June 21 & 1 & 3 & 0 & 0 & & & \\
\hline June 23 & 3 & 3 & 2 & 1 & 3 & 2 & \\
\hline June 24 & 0 & 0 & 1 & 0 & 0 & 0 & \\
\hline June 25 & 0 & 0 & 1 & 1 & 1 & 1 & \\
\hline June 30 & 0 & 0 & 1 & 0 & 0 & 0 & \\
\hline July 7 & 1 & 2 & 3 & 7 & 5 & 8 & \\
\hline July 12 & 15 & 16 & 6 & 21 & 3 & 4 & 17 \\
\hline July 21 & $\ldots$ & .. & 5 & 6 & 4 & 4 & 21 \\
\hline July 28 & .. & .. & 30 & 23 & 19 & 33 & \\
\hline
\end{tabular}

increased in size a heavier dosage was necessary ( 15 to 18 pounds per acre) to get good coverage. In the experiments carried out at Windsor, repeated applications were made on account of the 
many rains in June with extensive burning as a result. The injury to the foliage was negligible when compared with the injury to the base of the stalk (Figure 30). It seems that the dust was washed off the leaves by successive rains and carried down the main stalk to its base at the soil surface. This accumulation of poison produced a condition quite similar to that which is known as "soreshin," the stalk becoming black and rotten. In some cases the stalk eventually broke off at this point.

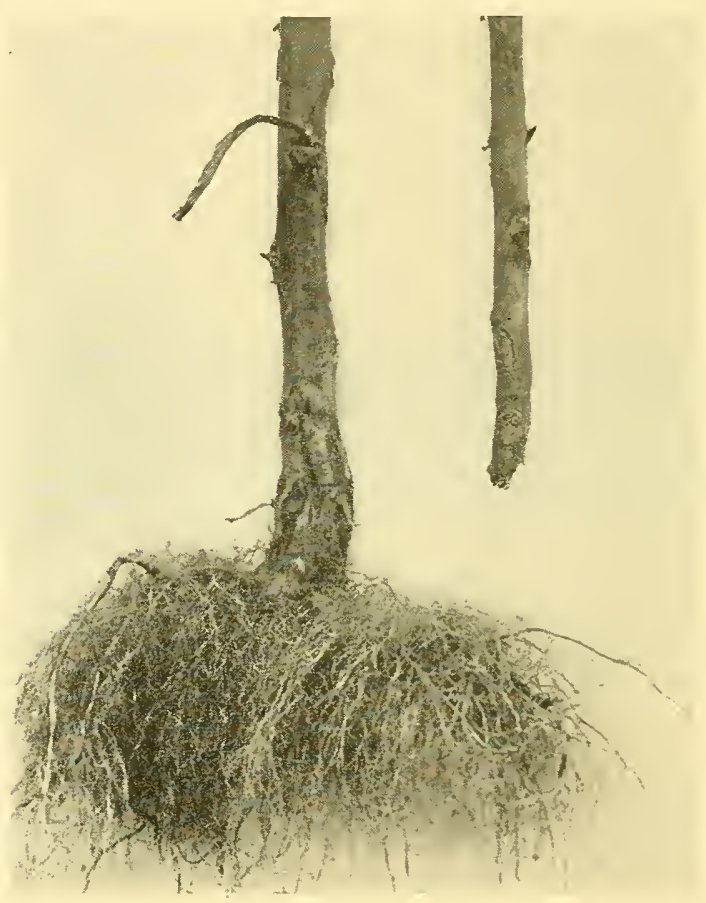

Figure 30. Paris green and calcium arsenate injury to base of stalk.

This condition was found on shade grown as well as on Havana Seed treated with the same mixture. All of the shade grown tobacco dusted with this mixture at full strength suffered from this burning and about 50 per cent of the Havana Seed. Where the paris green-calcium arsenate mixture was used diluted witl lime (one to five) the poison injury was slight. The Havana Seed tobacco that was dusted with full strength mixture was uniformly smaller than the check.

Table 40 gives the comparisons in figures of the numbers of beetles found on 20 plants in each case. 


\section{Cryolite}

This substance is a fluoride of aluminum and sodium, and under ordinary conditions is relatively insoluble, thus reducing the chances of foliage injury when used on plants. It is not toxic to man and animals, but is poisonous to insects.

Cryolite was used at full strength and also diluted one to five with hydrated lime, and kept the flea beetle population down to a fairly low figure. See Table 40.

\section{Barium Fluosilicate}

This material has been used with some success against the flea beetle in the South, and was tried on several experimental plots this season at Windsor. It is also a substance of low solubility and therefore not dangerous to use on foliage. It is said to act somewhat more slowly as a poison than does cryolite, but it kept the flea beetle population down to a minimum. As with cryolite, no foliage injury from its use was observed on the experimental plots.

While the differences in beetle population on treated and untreated plots were not great at first, there certainly was a great difference between treated and untreated shade grown tobacco at the time of the peak of emergence. For instance, on July 21 the treated shade grown tobacco had, in the case of cryolite, five and six beetles per 20 plants, while the untreated shade had a population of 219; on the same date, the untreated sun grown tobacco, just outside the tent, had 71 beetles per 20 plants. These figures are certainly of some significance.

Cryolite and barium fluosilicate were also used on two plots of late-planted strain-test varieties to check the beetles that might migrate from the earlier tobacco as it was being harvested. The dusts were used at full strength and were applied at the rate of about 30 pounds per acre. At the time of application, July 28, there were 137 and 141 beetles per 20 plants on the barium fluosilicate and cryolite plots respectively. Four days later, August 1, there were 97 and 92 respectively with 131 on the check. On August 9 there were 32 and 18 per 20 plants respectively and 51 on the check. The beetle population dropped off so rapidly on the untreated check plants as well as on the dusted ones after that date, that it was impossible to say that the scarcity of this pest was due to the effect of the poison or to a natural seasonal decline in abundance.

The problem of residue on the foliage is one factor that stands in the way of the use of insecticides on Connecticut grown leaf. For this reason, the dustings were discontinued after July 16 on the Havana Seed. About a week later the beetles became very abundant on these plots, causing damage of commercial importance. This means that the beetle must be completely suppressed in its first brood, or that some insecticide must be found that may be used up until harvesting time and that will leave no troublesome residue. 


\section{Miscellaneous Observations on Tobacco Insects}

Flea Beetle, Epitrix cucumeris Harris

In order to determine the nature of the activities of this insect on tobacco, daily observations were made on the plantation at the Tobacco Substation. Twenty plants were marked in each of five

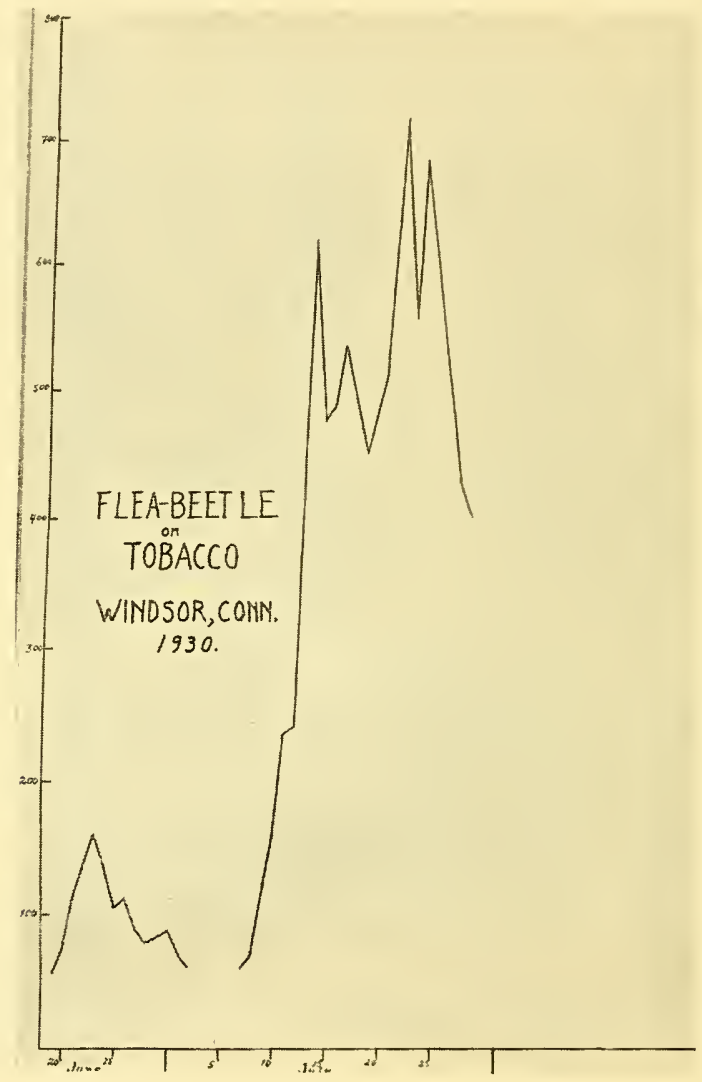

Figure 31. Flea beetle population on tobacco at Station plantation, 1930.

parts of the field, and the beetles on each of the plants in these sections were counted every day. One of these sections, No. 5, was on the shade grown tobacco. Table 41 contains the figures showing the daily population secured in this manner.

The flea beetle is more abundant on shade grown tobacco in the later part of the season, reaching its peak of abundance about ten 
days to two weeks earlier than the beetles on sun grown tobacco. A comparison of these facts is represented graphically in figures 31 and 32. Also the peak of abundance on shade grown tobacco coincides with or closely approximates the picking of the first leaves. There appears to be a smaller increase in numbers early in July, followed by a decline, which suggests that there are at least two broods. By the middle of August few beetles could be found on any plantation, and by August 20, they had practically disappeared.

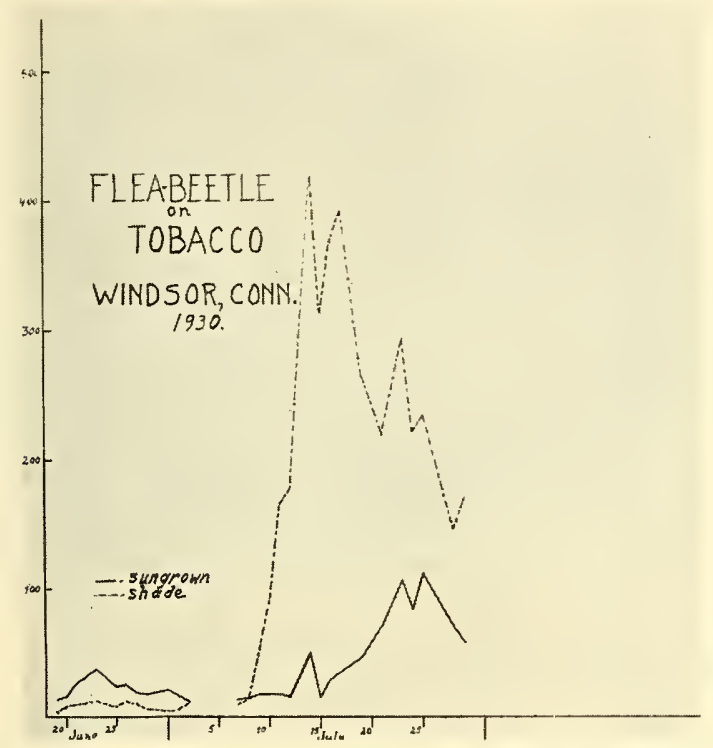

Figure 32. Comparison of flea beetle population on shade and sun grown tobacco at station.

Although this pest may riddle the leaves of the young plants during June, its more serious form of damage is done from midJuly to late July, particularly on the shade grown foliage. At this period of its existence it feeds on both surfaces of the leaf, while earlier it confines its activities to the lower side only. After the lower leaves have been "primed" it migrates up to the next highest foliage and continues its feeding.

The potato is the favorite food plant of this species, and under circumstances where potato and tobacco fields are planted side by side, the potatoes have been observed to suffer more than the tobacco. In one field, the tobacco next to heavily infested potatoes 
Table 41. Flea Beetle Population on Station Tobacco

Taken on 100 Plants, 20 in Each of Five Parts of Field

\begin{tabular}{|c|c|c|c|c|c|c|}
\hline Date 1930 & $\begin{array}{l}\text { No. beetles } \\
\text { on Sec. } 1\end{array}$ & $\begin{array}{l}\text { No. beetles } \\
\text { on Sec. } 2\end{array}$ & $\begin{array}{l}\text { No. beetles } \\
\text { on Sec. } 3\end{array}$ & $\begin{array}{l}\text { No. beetles } \\
\text { on Sec. } 4\end{array}$ & $\begin{array}{l}\text { No. beetles } \\
\text { on Sec. } 5\end{array}$ & $\begin{array}{l}\text { Daily } \\
\text { total }\end{array}$ \\
\hline June 19 & 5 & 6 & 11 & 31 & 3 & 56 \\
\hline June 20 & 8 & 15 & 16 & 27 & 8 & 74 \\
\hline June 21 & 18 & 16 & 30 & 39 & 9 & 112 \\
\hline J une 23 & 49 & 38 & 27 & 34 & 12 & 160 \\
\hline June 24 & 34 & 27 & 31 & 33 & 9 & 134 \\
\hline June 25 & 36 & 15 & 24 & 23 & 8 & 106 \\
\hline June 26 & 35 & 9 & 31 & 24 & 12 & 111 \\
\hline June 27 & 25 & 14 & 20 & 20 & 10 & 89 \\
\hline June 28 & 24 & 20 & 13 & 17 & 5 & 79 \\
\hline June 30 & 33 & 20 & 15 & 15 & 4 & 87 \\
\hline July 1 & 30 & 16 & 12 & 6 & 5 & 69 \\
\hline July 2 & 13 & 14 & 13 & 10 & 10 & 60 \\
\hline July 7 & 29 & 12 & 3 & 8 & 7 & 59 \\
\hline July 8 & 22 & 10 & 8 & 16 & 14 & 70 \\
\hline July 9 & 31 & 20 & 5 & 13 & 53 & 122 \\
\hline July 10 & 23 & 16 & 7 & 23 & 93 & 162 \\
\hline July 11 & 13 & 23 & 7 & 26 & 166 & 235 \\
\hline July 12 & 9 & 21 & 6 & 27 & 178 & $2+1$ \\
\hline Ju'y 14 & 23 & 73 & 18 & 87 & 418 & 619 \\
\hline July 15 & 29 & 45 & 17 & 71 & 313 & 475 \\
\hline July 16 & 24 & 37 & 18 & 39 & 368 & 486 \\
\hline July 17 & 18 & 48 & 27 & 49 & 393 & 535 \\
\hline July 19 & 37 & 73 & 21 & 53 & $26 t$ & 448 \\
\hline July 21 & 75 & 80 & 67 & 71 & 219 & 512 \\
\hline July 23 & 74 & 176 & 89 & 85 & 293 & 717 \\
\hline July 24 & 83 & 134 & 58 & 57 & 221 & 553 \\
\hline July 25 & 66 & 248 & 58 & 78 & 234 & 684 \\
\hline July 28 & 101 & 85 & 37 & 59 & 145 & 427 \\
\hline July 29 & 90 & 63 & 31 & 47 & 170 & 401 \\
\hline Totals & 1,057 & 1,374 & 720 & 1,088 & 3,644 & 7,883 \\
\hline
\end{tabular}

was free from the flea beetle until the potato vines began to dry up. Then the tobacco next to the potatoes became infested.

A tomato plant and a potato vine were placed in a row of tobacco that was heavily infested with beetles, and in a few days the insect was far more abundant on the potato than on either the tomato or the tobacco plant nearest. These facts suggest that it may be possible to make up a poisoned bait, using for an attractant the juice of potato vines or the substance that gives the potato its characteristic odor and flavor. 


\section{Grasshoppers}

On July 18,1930 , our attention was called to a sudden infestation of grasshoppers on 181-2 acres of shade grown tobacco in Avon. Most of the hoppers were young nymphs (probably Melanoplus atlantis Riley) apparently not more than a week old and had started toward the complete devastation of the crop. About 90 per cent of the plants showed injury of the nature indi-

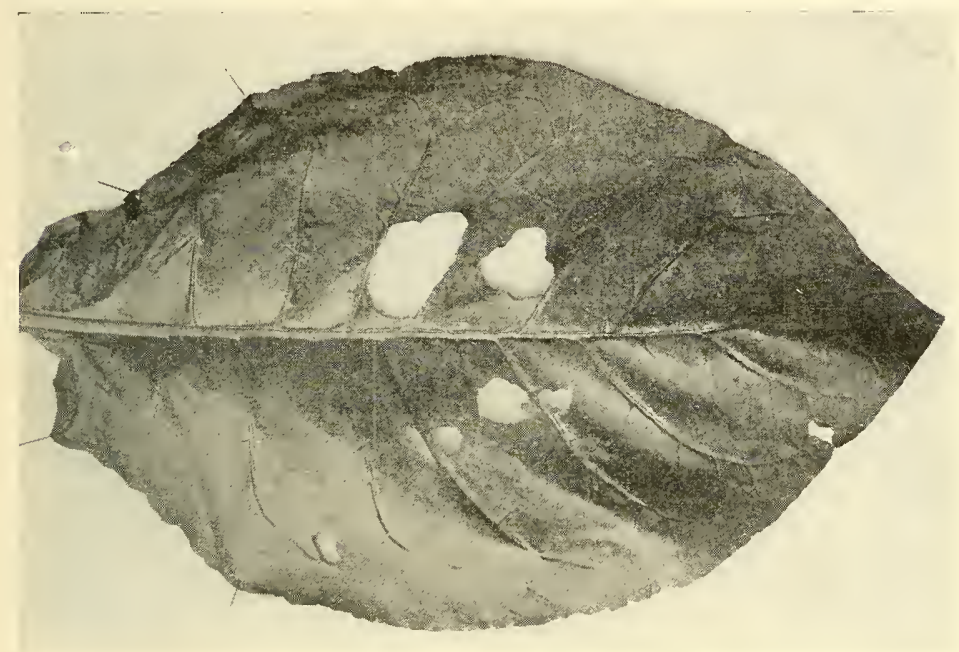

Figure 33. Grasshopper injury to leaves.

cated in Figure 33, and individual plants had anywhere from one to six leaves with such holes in them. Badly infested plants had as many as ten holes to a leaf. The manager hired boys to handpick the hoppers, but judging from the size of the insects at that stage and their activity, it is doubtful that the boys were able to catch more than one in four.

The immediate use of poisoned bran bait was advised, and the following standard mixture was made up:

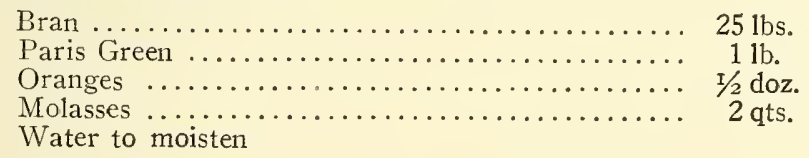

This material was scattered on the ground between every other row.

A visit to the plantation on July 21 showed that about 75 per cent of the grasshoppers had disappeared. At this time, the bait 
that was left over from the first application was being scattered between the rows not treated before. On July 24 it was estimated that about 90 per cent of the hoppers were gone.

A careful examination of the ground resulted in the recovery of some dead grasshoppers and many dead and dying ground beetles. The hoppers were hard to find because of their small size and because of the fact that they turn brown and shrivel up soon after death. All of these and some that were taken before the application of the poison were submitted to chemical tests for the presence of arsenic. The dead hoppers and dead ground beetles gave positive reactions to the tests, while the hoppers collected before the use of the poison reacted negatively.

An estimate of the costs involved for the 18.5 acre field was made by the manager of the plantation. They are as follows:

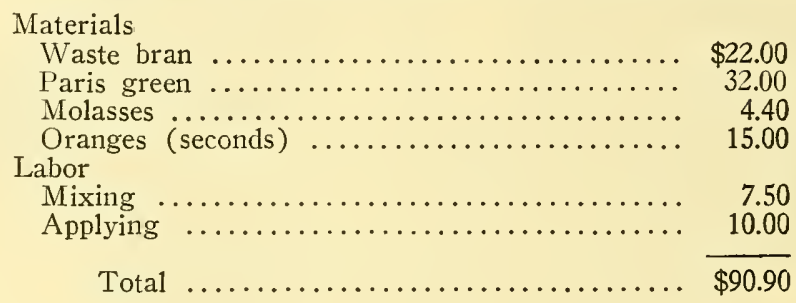

CAUTION: This mixture will cause serious burning if allowed to come in contact with or remain on the foliage. Domestic animals and fowl should be kept away.

It is unusual to find grasshopper infestations under shade unless it be along the edges of the fields. In the above cited instance, the land had been in hay the year previous to planting tobacco, and in alfalfa for several years prior to that. As stated above, the principal species in this infestation was thought to have been the lesser migratory locust, Melanoplus atlantis Riley. It was in a very young nymphal stage. A few mature red-legged grasshoppers, $M$. femur-rubrum DeG., were found, and an occasional carolina locust, $D$. carolina $\mathrm{L}$.

Another field (Broadleaf in this case) in Windsor Locks was being damaged by the red-legged grasshopper, and the Carolina grasshopper. It was a three-acre piece surrounded by hay land, and as soon as the hay had been cut, the hoppers migrated to the tobacco. While the edges of the field were attacked more seriously, the hoppers found their way to the middle. A single application of the grasshopper bait was sufficient to kill them all off in the center, and two applications in the immediate grass land and along the outside rows of tobacco completed the control measures very satisfactorily. Two days after the first application, dead hoppers could be picked up by the handful. 


\section{Late Infestation of Wireworms}

A late infestation of wireworms was found at Burnside on August 16 in a field of Broadleaf. The larvae had apparently

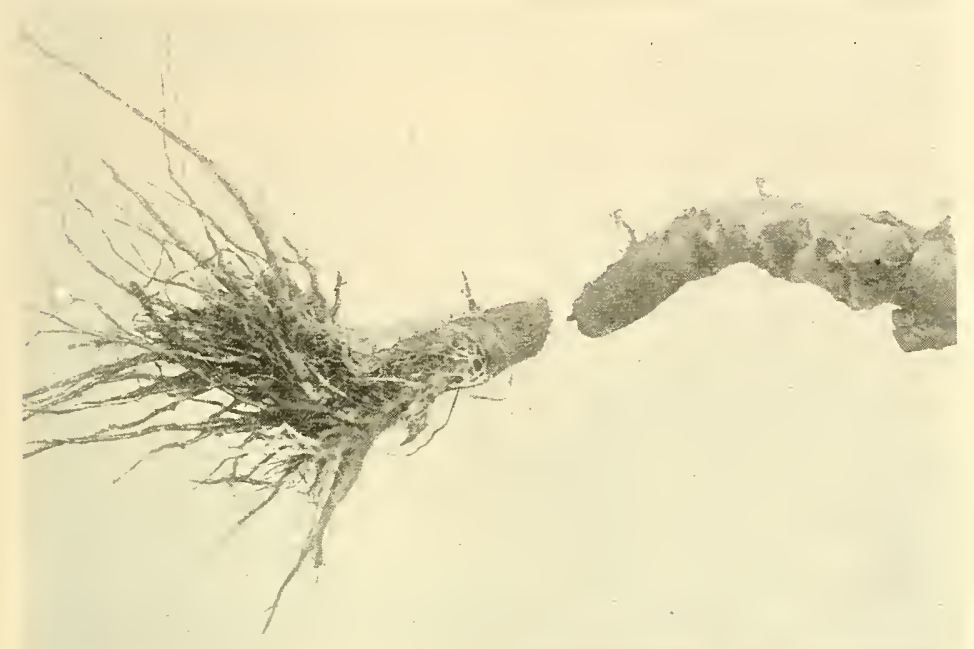

FigURE 34 . Wireworm injury to large tobacco stalks.

been at work for some time as plants of all sizes could be found infested with them. Thirteen worms were taken from one plant.

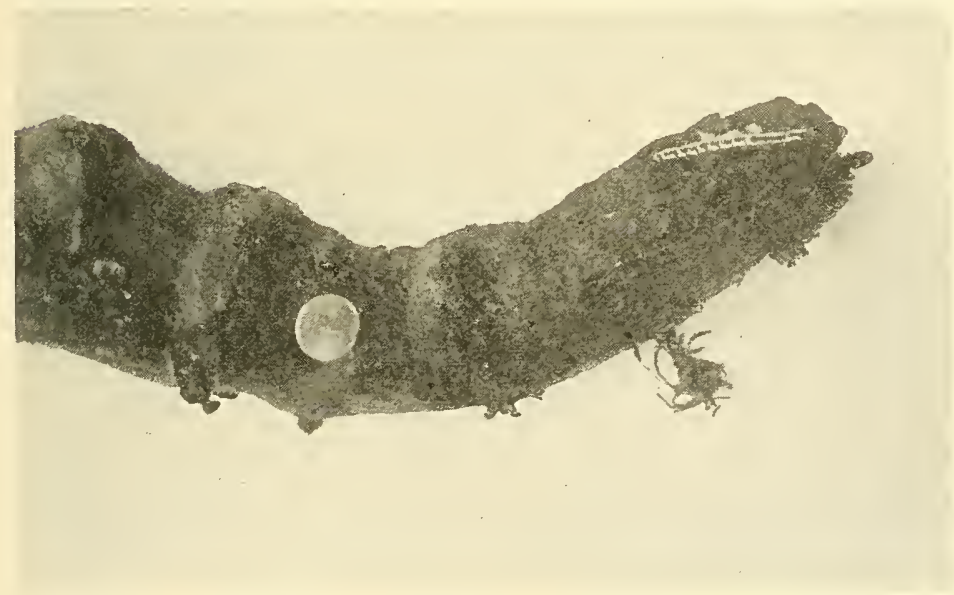

Figure 35. Specimen of wireworm on injured stalk. 
The injury (shown in Figures 34 and 35) resulted in malformed plants, dwarfed plants and chlorotic foliage. In some instances, half-grown plants had been bored and tunnelled so extensively that they broke off at the soil surface. Still others were connected with the root system only by a few rotting strands of plant tissue, so that a gentle pull broke them off completely. Areas infested ranged in size from single plants up to a square rod or so. A late infestation of this nature is unusual.

\section{Stalk Borer}

The common stalk borer, Papaipena nitela Guen., (Figure 29) was found tunnelling tobacco stalks in a few fields. This insect usually works on the outside rows near weedy borders. The larva enters the stalk an inch or so above the soil surface (Figure 36 )

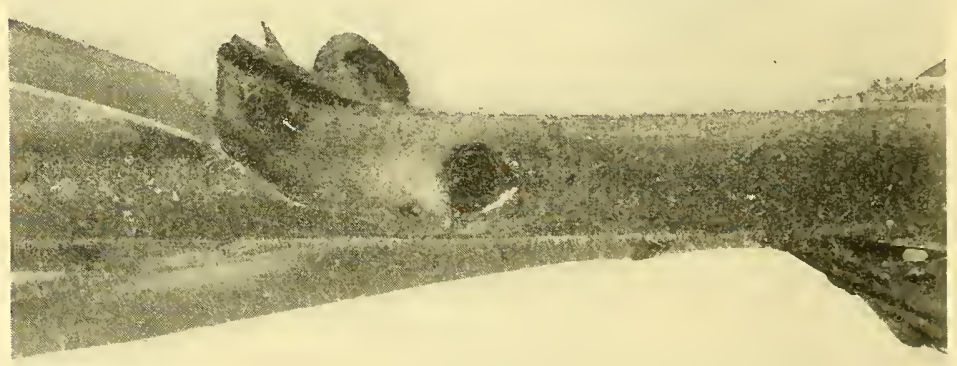

FIGURE 36. Stalk borer entrance in sucker.

and bores out the pith from root to growing tip. Practically all summer is spent in the larval stage, and only one borer lives in a stalk. Infested plants transplanted in breeding cages tended to send out abnormal growth of suckers. In one case, the main stalk dried up and two suckers took its place, one of these being tunnelled by the original borer.

\section{Hornworms}

Both species of hornworm were found on tobacco this season. The first larvae were found in the latter part of July in Suffield and were anywhere from one-third to full grown at this time. On August 18, half-grown as well as full-grown worms were found in New Milford. The only larvae of the southern species taken 
this season were found on the Experiment Station plots in Windsor.

Pupation in rearing cages started in late July and continted through late August. No moths had emerged by August 23. A third species, the white lined sphinx, Celerio lineata Fab., was taken on tobacco as a larva July 18. It pupated July 20 and emerged on August 13.

\section{Paris Green Injury to Tobacco}

Our attention was called to foliage injury resulting from the promiscuous scattering of cutworm bait on a field of young plants.
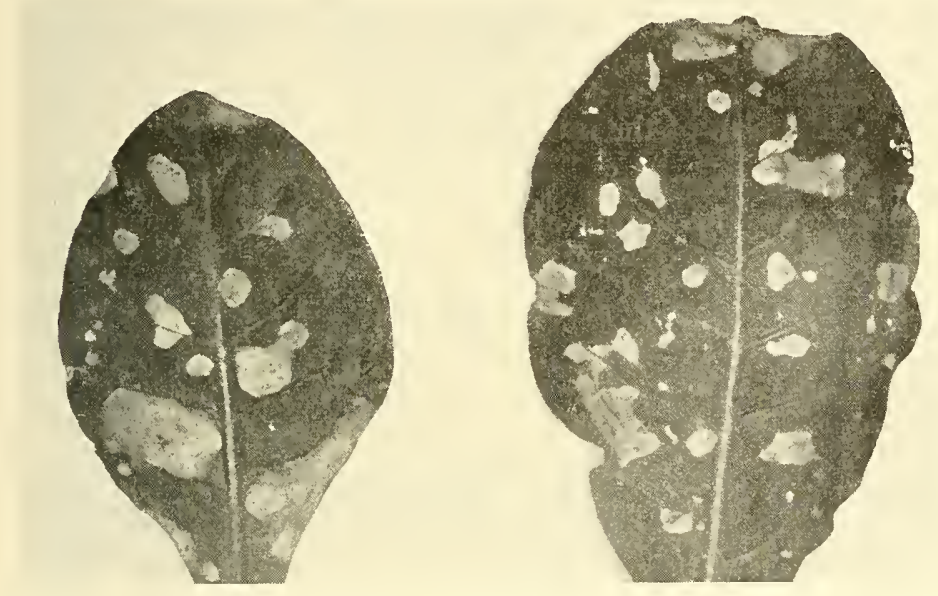

Figrue 37. Paris green injury to shade leaves.

A shade grown field had been treated with bran and paris green and the mixture had been allowed to lodge on the foliage of nearly every plant, with the result that most of the leaves were severely burned. Figure 37 shows how paris green spots the leaves.

Some burning was also observed on the field treated for grasshopper. The manager realized that burning would result from the poisoned bait lodging on the foliage and cautioned his men. However, accidental spilling occurred and resulted in injury worse than that of the grasshoppers. 


\title{
FERTILIZER LOSSES THROUGH LEACHING AS MEASURED BY LYSIMETER EXPERIMENTS
}

\author{
M. F. Morgan, O. E. Street and H. G. M. Jacobson
}

As reported in Bulletin 311, a lysimeter equipment was installed at Windsor in the spring of 1929 for the purpose of studying the losses of plant food elements through leaching, as affected by soil type, character of the fertilizer and crop removal. It is common knowledge that the leaching of fertilizer during wet seasons is a serious problem in tobacco production, particularly on our sandy soils. Although less conspicuously in evidence, the fate of fertilizer ingredients that are applied in excess of crop removal in our heavy tobacco fertilizer practice is an important factor in the cumulative effect of continuous tobacco culture upon the productive power of the soil. Much light should be thrown upon these problems by means of the experiments now in progress.

Briefly, the plan of the investigations is as follows:

Surface soil lysimeters. Cylindrical tanks 20 inches in diameter containing only the normal depth (seven inches) of surface soil are used in this experiment. Four different soils are compared:

1. An excessively sandy soil from the "plains," designated as Merrimac coarse sand; taken from a shade field operated by $\mathrm{H}$. C. Griswold in the town of Windsor Locks.

2. A medium sandy loam of the type most generally used for tobacco, designated as Merrimac sandy loam; taken from the Tobacco Substation field.

3. A very fine sandy loam, characteristic of the lighter textured soils of the gently rolling low uplands that occur just east of the level terraces lying east of the Connecticut River, designated as Enfield very fine sandy loam; taken from a field owned by P. Chamberlain, near Broad Brook.

4. A reddish brown loam, typical of the heavier upland soils which are derived from red (Triassic) sandstone glacial till, designated as Wethersfield loam; taken from a field owned by Olds and Whipple, in the town of Suffield.

On each of these soils the following forms of fertilizer nitrogen are compared, each used in amounts equivalent to 200 pounds of nitrogen per acre per year: nitrate of soda, sulfate of ammonia, urea and cottonseed meal. Precipitated bone, carbonate of potash, sulfate of potash and sulfate of magnesia are added to each tank in amounts sufficient to supply 100 pounds of phosphoric acid, 200 pounds of potash and 25 pounds of magnesia per acre per year.

The Merrimac sandy loam soil (No. 2) also includes tanks without nitrogen, but with other nutrients applied at the usual rate. All treatments are in duplicate.

All of the surface soil lysimeters are uncropped, since this experiment is primarily designed to study the absolute amounts of nitrogen that become available and leach through the surface soil 
at different periods of the year from various sources of nitrogen on the different soils.

Twenty-inch lysimeters. These are cylindrical tanks 20 inches in diameter and 20 inches deep, containing surface of normal depth (seven inches) placed over about 12 inches of subsoil. All the soil for this experiment is the Merrimac sandy loam from the Tobacco Substation field, identical with the one used in the surface soil lysimeters.

In this experiment a comparison is made between the following sixteen nitrogenous fertilizers:

Mineral and synthetic sources

Nitrate nitrogen $\left\{\begin{array}{l}\text { nitrate of soda } \\ \text { nitrate of potash } \\ \text { nitrate of lime }\end{array}\right.$

Ammonia nitrogen $\left\{\begin{array}{l}\text { sulfate of ammonia } \\ \text { ammophos " } B "\end{array}\right.$

Urea

Calurea (containing both urea and nitrate of lime)

Cyanamid

Vegetable organic sources

Cottonseed meal

Castor pomace

Linseed meal

Animal organic sources

Dry ground fish meal

Hoof and horn meal

Dried blood

Animal tankage

Cow manure

In all cases precipitated bone, carbonate of potash, sulfate of potash and sulfate of magnesia are added in amounts sufficient to supply the soil in the tanks with a total of 100 pounds of phosphoric acid, 200 pounds potash and 25 pounds of magnesia, except that the nitrate of potash necessary to furnish the required amount of nitrogen also supplied 677 pounds of potash, while the ammophos yielded 312 pounds of phosphoric acid. ${ }^{1}$

One tobacco plant is grown to normal harvest maturity on each of the 20 -inch tanks. In 1929 the crop was destroyed by hail just before harvest time and the crop was chopped up and returned to the soil, as was the common field practice following the severe hailstorm that year. The crop of 1930 was harvested, dried, weighed and analyzed, in order to obtain data on crop removal of plant food elements.

Whenever a sufficient amount of rain has fallen to produce leaching, the leachate is measured and sampled, and the nitrate nitrogen content of the leachate is determined. Complete chemical analyses

\footnotetext{
${ }^{1}$ In 1929 errors in preliminary data on the nitrogen content of the fertilizer material caused the use of 227 pounds of nitrogen as cyanamid and 280.6 pounds of nitrogen as hoof and horn meal.
} 
of the composite samples of the leachings from each tank are made for two six-months periods for each year beginning about May 25. This is the normal date for the fertilizer applications that are made just before tobacco setting.

The data collected during the year ending May 25, 1930, and for the six-months period ending November 25,1930 , will be briefly summarized in order to show the character of the results and for comparison with those of future years. It is to be remembered that soil leaching is dependent upon weather conditions, which fluctuate from season to season. These have been abnormal for practically the entire period since the beginning of these experiments.

The rainfall since May 25, 1929, has been unusually low almost every month. The year ending May 25, 1930, showed a rainfall of only 32.75 inches, which is about 12 inches below normal. For the six-months period ending November 25, 1930, the rainfall showed a corresponding deficiency.

In the tobacco growing season of 1929 , no leaching occurred, except about 0.2 of an inch from the sandiest soil, until the heavy rain and hailstorm, which destroyed the crop on August 1. More than two inches of rain at this time saturated all the soils and produced leaching, except in the 20 -inch tanks.

The amounts of leaching in terms of equivalent inches of rainfall for the different soils during 1929-1930 were as follows:

\begin{tabular}{|c|c|c|c|c|}
\hline Surface soil tanks & $\begin{array}{l}\text { May 26- } \\
\text { Aug. } 4,1929\end{array}$ & $\begin{array}{c}\text { May 26- } \\
\text { Nov.25,1929 }\end{array}$ & $\begin{array}{l}\text { Nov. } 26,1929- \\
\text { May 25, } 1930\end{array}$ & $\begin{array}{l}\text { Total } \\
\text { for year }\end{array}$ \\
\hline Merrimac coarse sand & 1.885 & 5.9 & 7.7 & 13.6 \\
\hline Merrimac sandy loam & 1.255 & 4.6 & 6.4 & 11.0 \\
\hline Enfield v. f. s. $1 . \ldots \ldots \ldots \ldots$ & 0.527 & 2.9 & 5.8 & 8.7 \\
\hline Wethersfield loam ......... & 0.760 & 3.8 & 6.7 & 10.5 \\
\hline $\begin{array}{l}\text { Twenty-inch tanks } \\
\text { Merrimac sandy loam }\end{array}$ & & 24 & 60 & 84 \\
\hline
\end{tabular}

During the growing season of 1930 , heavy rains at the end of May and in early June produced leaching of all the soils. No further rain of significant volume to produce leaching occurred until August 20, after the tobacco was harvested, and the season continued very dry until the heavy rains of November.

Leachings during the first six months of the 1930-1931 lysimeter year, and for the rainy period of May 26 to June 11 are shown below, in equivalent inches of rainfall.

\begin{tabular}{ccc}
\multicolumn{1}{c}{ Surface soil tanks } & $\begin{array}{c}\text { May 26- } \\
\text { June 11,1930 }\end{array}$ & $\begin{array}{c}\text { Mav 26- } \\
\text { Nov. 25, 1930 }\end{array}$ \\
Merrimac coarse sand $\ldots \ldots \ldots \ldots \ldots$ & 2.019 & 5.268 \\
Merrimac sandy loam $\ldots \ldots \ldots \ldots \ldots$ & 1.729 & 4.649 \\
Enfield v. f. s. 1. $\ldots \ldots \ldots \ldots \ldots \ldots$ & 1.208 & 3.324 \\
Wethersfield loam $\ldots \ldots \ldots \ldots \ldots \ldots$ & 1.621 & 4.407 \\
$\quad$ Twenty-inch tanks & & \\
Merrimac sandy loam $\ldots \ldots \ldots \ldots$ & 1.166 & 2.470
\end{tabular}


It is thus seen that a distinct difference appeared in the distribution of the rainfall in the growing seasons of 1929 and 1930. In 1929 leaching did not occur until at the end of the period, practically all being collected on August 1 and August 4, more than two months after the fertilizer was applied. In 1930 all the leaching occurred in the first two weeks, before the nitrification of the non-nitrate forms of nitrogen had time to reach a maximum. This difference is clearly evident in a comparison of the amount of nitrate nitrogen and its maximum concentration during these periods of leaching.

Table 42. Nitrate Nitrogen Leached from the Surface-Sorl Lysimeters in the Growing Seasons of 1929 and 1930

Soil and treatment

Merrimac coarse sand

Nitrate of soda

ammonia ..........

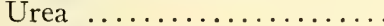

Cottonseed meal ...........

Merrimac sandy loam

Nitrate of soda ...........

Sulfate of ammonia ........

Urea ...................

Cottonseed meal ...........

No nitrogen

Enfield v. f. s. 1.

Nitrate of soda ...........

Sulfate of ammonia ........

Urea ....................

Cottonseed meal

Wethersfield loam

Nitrate of soda ...........

Sulfate of ammonia ........

Urea ....................

Cottonseed meal

$$
\overbrace{1929}^{\text {Lbs. per acre }} \underset{1930}{\longrightarrow}
$$

97.394

36.013

70.153

64.813

113.401

59.661

82.132

65.207

25.701

33.299

12.273

17.740

13.907

60.879

21.975

37.851

33.871

127.631
17.344
33.413
9.478

102.914

21.612

37.447

9.408

10.684

36.917

12.940

14.343

9.119

85.459

13.434

48.971

10.140

Maximum concentration of leachate, in parts per million $1929 \quad 1930$

400

108

198

175

667

67

150

33

540

630

$294 \quad 86$

$333 \quad 180$

$302 \quad 30$

15538

The greater volume of leachate in the growing season of 1930 explains the somewhat greater losses of nitrogen from the nitrate of soda treatments for three of the four soils. It is evident that during the first two weeks after fertilizer application cottonseed meal has produced a nitrate nitrogen concentration much lower than sulfate of ammonia and that urea has produced a concentration significantly higher. This indicates that nitrification of urea begins more promptly and it is believed that if it had continued to be wet during the latter half of June a serious loss of nitrogen from the urea-treated soils would have occurred.

The heavy losses of nitrogen from the nitrate of soda tanks on all soils except the Enfield very fine sandy loam show that leaching 
at any time during the season will remove much of the available nitrogen from the surface soil.

It is interesting to note that while the surface soil tanks of the Merrimac sandy loam in 1930 revealed a removal of more than half of the total application of nitrogen as nitrate of soda at the beginning of the growing season, the 20-inch tanks, with normal subsoils under the same surface soils, showed that this nitrogen was not lost to the crop. The loss from none of the 20 -inch tanks in the growing season exceeded 10 pounds per acre, while the crop of 1930 was able to take up more nitrogen from the tanks treated with nitrate of soda than from any other treatment. The data on crop removal on the 20-inch tanks in 1930 are shown in Table 43.

Table 43. Nitrogen Removed by 1930 Crop of Tobacco from 20-Inch LYSIMETER TANKS

\begin{tabular}{|c|c|c|}
\hline \multirow[t]{2}{*}{ 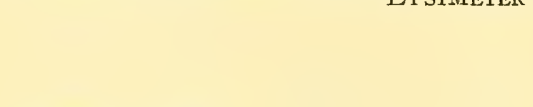 } & \multicolumn{2}{|c|}{ Average of duplicate tanks } \\
\hline & Lbs. peragere & $\begin{array}{l}\text { duplicate tanks- } \\
\text { Percentage of } \\
\text { nitrogen in dry har- } \\
\text { vested tobacco } 0^{1} \text { plants }\end{array}$ \\
\hline Nitrate of soda .. & 109.481 & 3.06 \\
\hline Ammophos "B" . & 107.107 & 3.14 \\
\hline Calurea $\ldots \ldots \ldots \ldots \ldots \ldots \ldots \ldots$ & 102.983 & 2.99 \\
\hline Urea $\ldots \ldots \ldots \ldots \ldots \ldots \ldots \ldots \ldots$ & 99.308 & 2.90 \\
\hline Nitrate of potash $\ldots \ldots \ldots \ldots \ldots \ldots$ & 98.560 & 3.20 \\
\hline 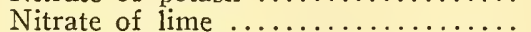 & 91.045 & 3.07 \\
\hline Sulfate of ammonia ............. & 89.585 & 3.15 \\
\hline 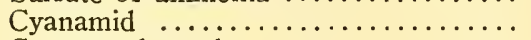 & $80.015^{2}$ & 3.42 \\
\hline Cottonseed meal ................ & 75.887 & 1.80 \\
\hline Castor pomace $\ldots \ldots \ldots \ldots \ldots \ldots \ldots$ & 76.922 & 2.07 \\
\hline Linseed meal . . . . . . . . . . . . . & 76.032 & 2.19 \\
\hline Dry ground fish $\ldots \ldots \ldots \ldots \ldots \ldots$ & 78.931 & 2.39 \\
\hline Hoof and horn meal ............. & 70.165 & 2.04 \\
\hline Dried blood ................... & 73.310 & 2.23 \\
\hline Tankage .................... & 69.121 & 2.02 \\
\hline Manure $\ldots \ldots \ldots \ldots \ldots \ldots \ldots \ldots \ldots$ & 52.659 & 1.68 \\
\hline No nitrogen $\ldots \ldots \ldots \ldots \ldots \ldots \ldots \ldots$ & 24.255 & 1.27 \\
\hline
\end{tabular}

It is evident from the above data that in spite of the leaching in early June, more nitrogen was available in the soil from all the non-organic nitrogenous materials than from the organic sources. The only plants that showed evident symptoms of nitrogen starvation were on the tanks without fertilizer nitrogen or with manure as the only source of nitrogen. This agrees with field observations, where nitrogen deficiency was noted only on soils similar to the Merrimac coarse sand, with nitrate of soda as the chief source of the element.

By November 25, the end of the first six-months period, in both years practically the entire application of nitrate of soda was

\footnotetext{
${ }^{1}$ Analyses by Dr. E. M. Bailey, head of the Department of Analytical Chemistry.

${ }^{2}$ Two plants per pot on these tanks.
} 
leached from all the surface soils. The 20-inch lysimeters were not comparable in the two different years, since in 1929 the haildestroyed crop was returned to the soil. 'The nitrogen losses during the second six months of the first lysimeter year were very low on all the surface soils, although the bulk of the nitrogen losses from the 20 -inch tanks occurred during that period.

Table 44. Nitrate Nitrogen Leached from Surface SoIl Lysimeter TANKS IN 1929 AND 1930

\section{Pounds per acre}

Soil and treatment

Merrimac coarse sand

Nitrate of soda .....

Sulfate of ammonia..

Urea ...............

Cottonseed meal ....

Merrimac sandy loam

Nitrate of soda .....

Sulfate of ammonia..

Urea .............

Cottonseed meal .....

No nitrogen .......

Enfield v. f. s. 1.

Nitrate of soda .....

Sulfate of ammonia..

Urea .............

Cottonseed meal ....

Wethersfield loam

Nitrate of soda .....

Sulfate of ammonia..

Urea ..............

Cottonseed meal ..... $\begin{array}{cc}\text { May 26- } & \text { Nov. 26, } 1929 . \\ \text { Nov.25, } 1929 & \text { May 25, } 1930\end{array}$

May 26-

Nov. 25, 1930

Total to

Nov. 25, 1930

$\begin{array}{lrrr}208.207 & 6.727 & 218.608 & 423.542 \\ 117.982 & 6.050 & 72.939 & 196.971 \\ 148.637 & 5.963 & 90.509 & 245.109 \\ 138.032 & 6.594 & 80.324 & 224.950\end{array}$

250.328

201.161

219.708

174.612

76.379

12.056

11.451

10.413

12.421

11.768

233.918

172.383

169.164

119.132

58.771

496.302

384.996

389.285

306.165

146.918

192.525

14.127

210.662

164.265

417.314

146.581

142.732

107.984

16.291

16.291

153.350

93.597

335.677

312.373

222.206

167.216

158.359

160.451

99.714

$\begin{array}{rr}\mathbf{5 5 . 8 8 7} & 220.442 \\ 31.597 & 153.336 \\ 50.633 & 189.629 \\ 35.395 & 91.680\end{array}$

443.545

343.292

400.713

226.789

From the above table it is evident that urea is leached from the soil at a distinctly more rapid rate than cottonseed meal, and that its rapid transformation into nitrate nitrogen proceeds until practically all of the material is nitrified. Cottonseed meal has been more slowly and incompletely nitrified, and the 20-inch lysimeters show that this is true of all the organic ammoniates. Sulfate of ammonia begins to nitrify more slowly than urea, but the amount that becomes available as nitrates is as high or higher than for urea. This is true except on the Merrimac coarse sand, which is so sandy that it loses a considerable amount of ammonia nitrogen by leaching.

The leaching of ammonia nitrogen during the first lysimeter year was as follows: 
Table 45. Nitrogen Leacied as Ammonium Salts from Surface SorL Tanks. First Lysimeter Year (May 26, 1929, to May 25, 1930)

Pounds per acre

$\begin{array}{lccrc}\text { Merrimac coarse sand ...... } & \begin{array}{c}\text { Nitrate } \\ \text { of soda }\end{array} & \begin{array}{c}\text { Sulfate } \\ \text { of ammonia }\end{array} & \text { Urea } & \begin{array}{c}\text { Cottonseed } \\ \text { meal }\end{array} \\ \text { Merrimac sandy loam ....... } & 1.308 & 41.617 & 13.250 & 8.051 \\ \text { Enfield v. f. s. 1. ........... } & 2.421 & 5.171 & 2.197 & 2.156 \\ \text { Wethersfield loam ......... } & 0.702 & 1.165 & 0.700 & 0.978 \\ \end{array}$

The leaching of nitrate nitrogen from the 20-inch tanks has shown rather significant differences in the absolute loss of nitrogen through the subsoil for the different sources of nitrogen. This is shown in Table 46.

Table 46. Nitrate Nitrogen Leached from 20-Inch Lysimeter TANKS IN 1929 AND 1930

Pounds per acre

Treatment

Nitrate of soda .........

Nitrate of potash ......

Nitrate of lime ........

Sulfate of ammonia ....

Ammophos ............

Urea $\ldots \ldots \ldots \ldots \ldots \ldots$

Calurea...........

Cyanamid...$\cdots \ldots \ldots$.

Cottonseed meal .......

Castor pomace .........

Linseed meal ...........

Dry ground fish .........

Hoof and horn meal ...

Dried blood ............

Tankage .............

Manure ..............

No nitrogen...$\ldots \ldots$.

$\begin{array}{cc}\begin{array}{c}\text { May 26- } \\ \text { Nov.25, } 1929\end{array} & \begin{array}{c}\text { Nov. } 26,1929- \\ \text { May 25,1930 }\end{array} \\ 79.170 & 111.236 \\ 62.103 & 133.343 \\ 66.796 & 122.909 \\ 37.109 & 121.832 \\ 41.483 & 114.727 \\ 43.750 & 98.378 \\ 45.575 & 117.321 \\ 19.459 & 58.501 \\ 43.476 & 71.023 \\ 44.297 & 91.269 \\ 38.039 & 80.354 \\ 35.481 & 78.898 \\ 43.539 & 99.250 \\ 41.111 & 117.980 \\ 32.538 & 85.407 \\ 31.681 & 43.035 \\ 13.088 & 43.272\end{array}$

$\begin{array}{cc}\begin{array}{c}\text { May 26- } \\ \text { Nov. } 25,1930\end{array} & \begin{array}{c}\text { Total to } \\ \text { Nov. } 25,1930\end{array} \\ 76.173 & 266.579 \\ 59.964 & 255.410 \\ 52.159 & 241.864 \\ 28.819 & 187.760 \\ 40.398 & 196.608 \\ 38.569 & 180.697 \\ 49.003 & 211.899 \\ 44.659 & 122.619^{1} \\ 34.644 & 149.143 \\ 32.151 & 167.717 \\ 28.848 & 147.241 \\ 36.591 & 150.970 \\ 24.948 & 167.737^{2} \\ 32.026 & 181.117 \\ 30.423 & 148.368 \\ 34.977 & 109.693 \\ 15.296 & 71.656\end{array}$

\section{The Effect of Various Nitrogenous Fertilizers Upon the Leaching of the Basic Constituents of the Soil}

Since there are great differences in the amounts of nitrate nitrogen leached, which depend upon the form of nitrogen and the character of the soil, it is to be expected that there will be corresponding differences in the removal of the basic constituents, principally calcium, magnesium, potassium and sodium, from the soil by percolating water. Nitrate nitrogen is in the form of anions,

${ }^{2} 280.6$ pounds of nitrogen applied in 1929 . 
which are tied up with these cations, as chemical compounds dissolved in the leachate. The restilts of complete chemical analyses have verified this supposition.

Table 47. The Leaching of Basic Constituents from the Surface Soil. Lysimeter Tanks. The First Lysineter Year (May 26. 1929, to May 25, 1930)

Pounds per acre

\begin{tabular}{|c|c|c|c|c|}
\hline Soil and treatment & Calcium & Magnesium & Potassium & Sodium \\
\hline \multicolumn{5}{|l|}{ Merrimac coarse sand } \\
\hline Nitrate of soda $\ldots . . .$. & 68.700 & 11.168 & 50.388 & 299.298 \\
\hline Sulfate of ammonia .... & 153.123 & 14.415 & 62.767 & 13.567 \\
\hline Urea $\ldots \ldots \ldots \ldots \ldots$. & 112.891 & 11.056 & 49.203 & 10.027 \\
\hline Cottonseed meal ....... & 90.125 & 17.167 & 62.294 & 13.131 \\
\hline \multicolumn{5}{|l|}{ Merrimac sandy loam } \\
\hline Nitrate of soda $\ldots \ldots \ldots$ & 148.445 & 24.850 & 43.203 & 263.591 \\
\hline Sulfate of ammonia .... & 376.153 & 48.599 & 71.133 & 24.725 \\
\hline Urea $\ldots \ldots \ldots \ldots \ldots \ldots$ & 246.959 & 37.820 & 61.144 & 21.688 \\
\hline Cottonseed meal ....... & 204.239 & 32.710 & 63.633 & 17.399 \\
\hline No nitrogen...$\ldots \ldots$. & 122.769 & 19.098 & 59.583 & 9.469 \\
\hline \multicolumn{5}{|l|}{ Enfield v. f. s. 1 . } \\
\hline Nitrate of soda $\ldots . . . \cdots$ & 102.991 & 25.265 & 51.617 & $\begin{array}{r}164.851 \\
32.257\end{array}$ \\
\hline $\begin{array}{l}\text { Stultate of ammonia } \ldots \ldots \\
\text { Urea } \ldots \ldots \ldots \ldots \ldots \ldots\end{array}$ & 165.861 & $\begin{array}{l}3+.090 \\
35.031\end{array}$ & $\begin{array}{l}64.407 \\
51.342\end{array}$ & 24.699 \\
\hline Cottonseed meal ....... & 113.733 & 28.436 & 55.725 & 25.647 \\
\hline \multicolumn{5}{|l|}{ Wethersfield loam } \\
\hline Nitrate of soda .... & 162.803 & 24.314 & 11.999 & 186.533 \\
\hline Sulfate of ammonia .... & 341.436 & 34.328 & 13.321 & 40.183 \\
\hline Urea $\ldots \ldots \ldots \ldots \ldots \ldots$ & 238.594 & 25.647 & 12.888 & 48.833 \\
\hline Cottonseed meal ........ & 184.112 & 26.324 & 13.441 & 49.333 \\
\hline
\end{tabular}

On all soils, nitrate of soda shows a very high value for sodium leachings, with low figures for the other basic elements. On the two sandy soils, practically all the nitrate outgo can be accounted for as sodium nitrate. Sulfate of ammonia has very materially enhanced the leachings of calcium, magnesium and potassium Urea has produced materially greater calcium losses than has cottonseed meal, as would be expected with the more complete nitrification of the former material. Cottonseed meal and urea produced practically the same losses of magnesium, potassium and sodium.

Similar data for the 20-inch tanks, shown in Table 48, have confirmed these results, and show a close correlation between the calcium losses and the nitrate losses, except in the case of sodium nitrate, sulfate of ammonia and ammophos " $\mathrm{B}$ " (containing sulfate of ammonia). As in the shallow tanks, sodium nitrate has repressed the calcium outgo, while the sulfate of ammonia, furnishing the two soluble anions, has greatly enhanced it. 
Table 48. The Leaching of Basic Constituents from the 20-Inch

Tanis. The First Lysimeter Year (May 26, 1929, to May 25, 1930)

Pounds per acre

\begin{tabular}{|c|c|c|c|c|}
\hline Treatment & Calcium & Magnesium & Potassium & Sodium \\
\hline Nitrate of soda & 131.241 & 14.689 & 63.513 & 117.906 \\
\hline Nitrate of potash & 205.922 & 28.411 & 54.329 & 22.700 \\
\hline Nitrate of lime $\ldots \ldots \ldots \ldots$ & 215.054 & 23.112 & 46.609 & 19.836 \\
\hline Sulfate of ammonia ...... & 282.605 & 39.973 & 55.885 & 19.812 \\
\hline Ammophos "B" ......... & 245.876 & 36.598 & 51.228 & 20.265 \\
\hline Urea $\ldots \ldots \ldots \ldots \ldots \ldots \ldots$ & 168.265 & 19.981 & 52.759 & 14.376 \\
\hline Calurea ....... & 196.651 & 23.527 & 56.066 & 20.306 \\
\hline Cyanamid $\ldots \ldots \ldots \ldots \ldots$ & 96.414 & 15.351 & 57.441 & 20.049 \\
\hline Cottonseed meal ......... & 135.836 & 14.835 & 51.242 & 21.096 \\
\hline Castor pomace..$\ldots \ldots \ldots$ & 165.034 & 18.741 & $63.078^{1}$ & 15.827 \\
\hline Linseed meal $\ldots \ldots \ldots \ldots$ & 148.840 & 20.084 & 60.701 & 17.569 \\
\hline Dry ground fish $\ldots \ldots \ldots$ & 141.744 & 14.227 & 51.136 & 11.164 \\
\hline Hoof and horn meal ...... & 173.348 & 22.470 & 58.441 & 10.828 \\
\hline Dried blood ........... & 172.380 & 31.810 & 56.171 & 26.741 \\
\hline Tankage $\ldots \ldots \ldots \ldots \ldots$ & 143.866 & 16.124 & 50.096 & 27.848 \\
\hline Manure .... & 90.393 & 12.038 & 47.379 & 20.952 \\
\hline No nitrogen $\ldots \ldots \ldots \ldots \ldots$ & 76.485 & 18.773 & 52.138 & 20.785 \\
\hline
\end{tabular}

One very striking point in these data is the fact that nitrate of potash, furnishing 677 pounds of $\mathrm{K}_{2} \mathrm{O}$ per acre as compared with 200 pounds for all other applications, produced no increase in the amount of potassium in the leachate, although it caused almost as great a calcium outgo as did nitrate of lime. It appears that while sodium caused very little base exchange, potassium was almost completely absorbed by the soil, its place being taken by calcium in the leachate.

\section{Other Important Constituents of the Leachate from Soils Treated With Various Nitrogenous Fertilizers}

Besides the nitrate, there are two other important anions in the leachates: the sulfate and the bicarbonate. Since all of the soils are acid and no liming material was used in this experiment, no carbonates were present, and the bicarbonates were very low on the two most acid soils, Merrimac coarse sand and Enfield very fine sandy loam.

Tests for the chlorides showed a very low concentration in all the leachates, the outgo in no case exceeding one and one-half pounds per acre for the first year. No chlorides were used in the fertilizer. The concentration of phosphates was of about the same order of magnitude, and these two anions may be practically disregarded.

Some of the surface soil tanks, particularly those treated with sulfate of ammonia and urea, showed a distinctly acid leachate. In such cases significant amounts of manganese and aluminum were present.

\footnotetext{
${ }^{1}$ One hundred and fifty pounds potash applied in 1929.
} 
Table 49. Leachings of Certain Constituents from the Surface Soll Tanks and their Relationship to the Reaction of the Leachate. First Lysimeter Year (May 26, 1929, to May 25, 1930)

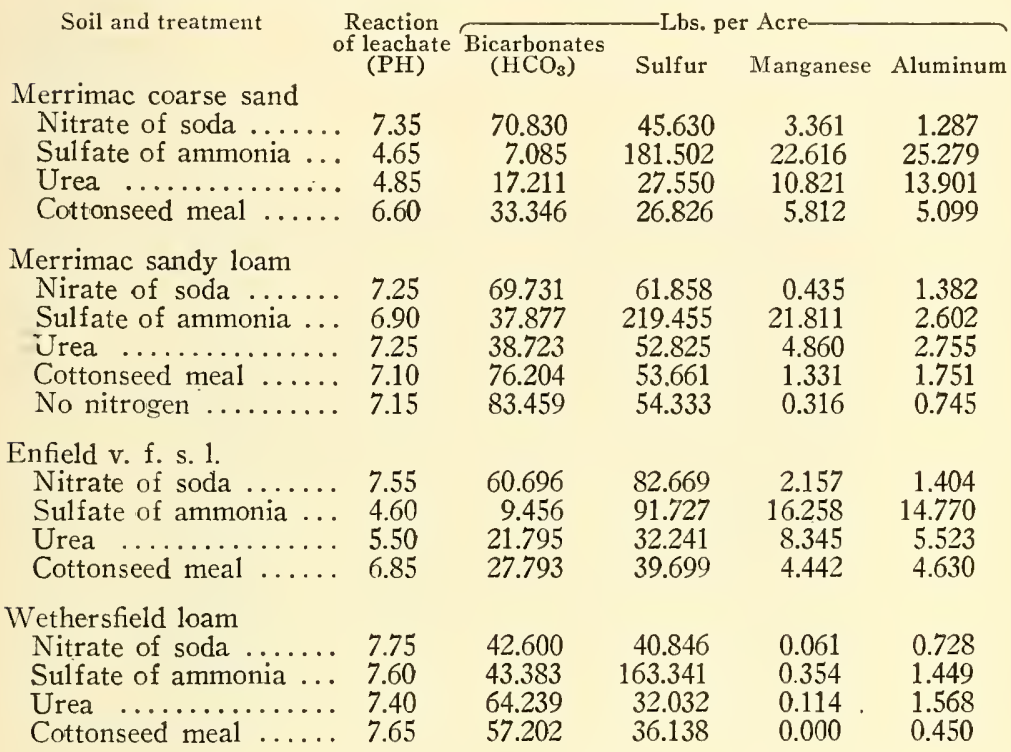

The 20-inch tanks produced leachates that were slightly alkaline in nearly all cases, the reaction varying from 7.0 to $8.2 \mathrm{pH}$ with no apparent correlation with fertilizer treatment. The manganese and aluminum concentration of all 20-inch leachates was almost negligible, which indicates that these elements, if leached from the surface soil of the Merrimac sandy loam, were absorbed in the subsoil.

The bicarbonates in the 20-inch leachate, expressed as $\left(\mathrm{HCO}_{3}\right)$ in the first lysimeter year ranged from 57 to 73 pounds per acre, with no apparent correlation with treatment.

The sulfate outgo, expressed as sulfur, for the same period from the same series of tanks ranged from 28 to 64 pounds per acre from all treatments except sulfate of ammonia and ammophos " $\mathrm{B}$ ". These were 148.231 and 103.112 pounds, respectively, which indicates the rapid outgo through the subsoil of heavy applications of sulfate material. 


\section{THE USE OF COKE IN HEATING TOBACCO SHEDS}

\section{J. S. OWENS ${ }^{1}$}

The use of artificial heat in curing tobacco must be determined by the effect on the quality of the product (including control of pole sweat) and the cost. Stalk growers in particular have con-

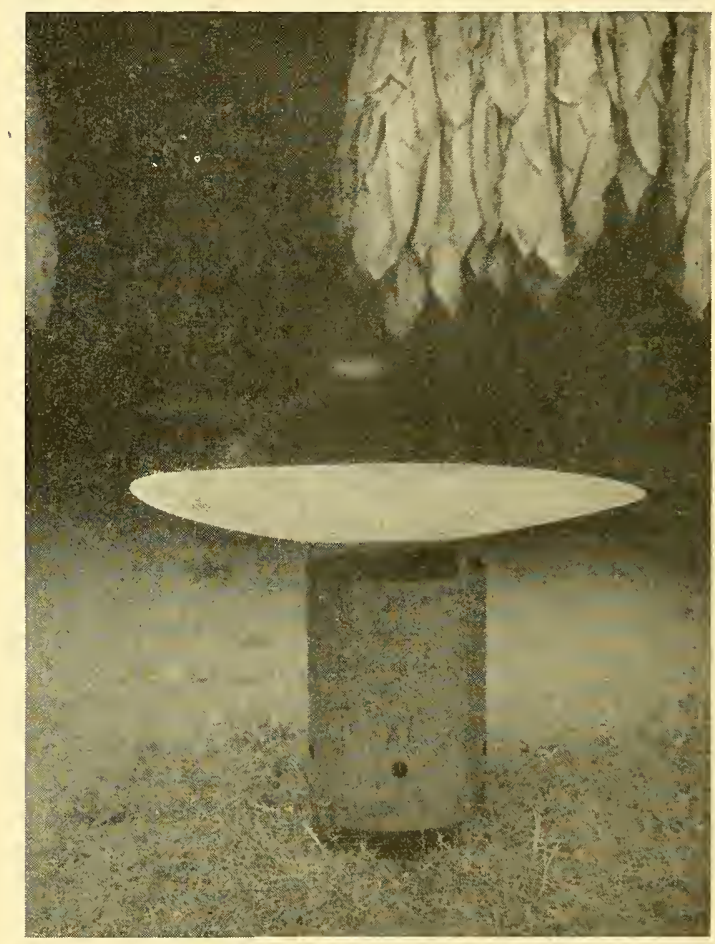

Frgure 38. Salamander and spreader designed for use in tobacco sheds. Note that 18-inch height permits spread of heat underneath lower tier of tobacco.

sidered the use of charcoal too costly, except when extreme danger of sweat is imminent. Gas coke has been used in the Burley district. Coke made from bituminous coal is now distributed widely in this state. This project was andertaken to determine

\footnotetext{
${ }^{1}$ Extension agronomist of the Connecticut Agricultural College. The project was conducted in coöperation with the Connecticut Coke Company and David M. Hadlow of that company assisted in developing the equipment used and in conducting the tests.
} 
whether coke might be used with good results and whether its cost for both labor and fuel compared favorably with charcoal.

In 1929, several types of salannanders or burners were developed and tried in empty sheds, at the Tobacco Substation, but loss of the crop by hail prevented using coke for curing trials there. Later in the season, coke fires were used in curing a small shed of tobacco on the farm of Lester Lloyd in Suffield. Except for some difficulty in keeping the grates clean, the coke fires appeared satisfactory.

On August 15, 1930, coke fires were started in shed No. 3 at the Station. This shed is 28 by 80 feet. Thirteen salamanders 12 inches in diameter and 16 inches high, and another 14 inches in diameter and 16 inches high, were distributed in two rows 12 feet apart. The salamanders were placed 13 feet apart in the rows and the rows were eight feet from the outside wall. The salamanders were made cylindrical, of sheet metal, fitted with a grate and covered with an inverted cone-shaped spreader of light metal, three feet in diameter. Thermometers located at varied elevations and distances from the burners showed variations within $4^{\circ} \mathrm{F}$. The distribution of heat was excellent in spite of a strong, cool wind and large cracks in the sides of the shed.

Thirty charcoal fires were started on the same day in shed No. 2, which is 28 by 93 feet. Fifteen fires were placed on each side and both sheds were heated 48 hours. Although an attempt was made to keep the sheds at approximately the same temperatures, the coke shed, with readings taken at the same time and in corresponding locations, averaged $7.2^{\circ} \mathrm{F}$. higher than the shed heated with charcoal, and $17.4^{\circ} \mathrm{F}$. above the outside temperature. Observations on the tobacco both at time of curing and when sorted. showed no difference in quality.

The coke consumed weighed 900 pounds, and the charcoal, 1.200. At prevaiting prices of $\$ 13$ and $\$ 20$ per ton respectively, the fuel cost was $\$ 5.85$ for the coke and $\$ 12.00$ for the charcoal. Reduced to the basis of equal shed area the cost for charcoal would have been $\$ 10.34$.

On September 5, a shed 128 by 30 feet, filled with Broadleaf, on the farm of John M. Herr, East Hartford, was heated with coke. Twenty-four salamanders were used. Twenty-three were 12 inches in diameter and 16 inches tall, and one was 14 inches in diameter and 16 inches tall. The fires were run continuously for 40 hours and an average temperature of $81.2^{\circ} \mathrm{F}$., or $12.9^{\circ}$ above outside temperature was maintained. One ton of stove size coke and 60 pounds of charcoal (for starting fires) were used.

Experience appears to warrant a few comparisons between coke and charcoal. In the test at the Tobacco Station more than 40 per cent of the fuel cost was saved by using coke. With 14 inch salamanders fitted with large mesh grates, attention was needed only every four to eight hours, while charcoal fires needed replen- 
ishing at periods ranging from 20 minutes to one hour. Coke gave a steady, practically odorless and smokeless heat, which with properly designed salamanders, and spreaders, was well distributed, and no trace of objectionable odor or injurious effect upon the tobacco appeared in any one of the three sheds so heated.

Charcoal fires are more flexible. They are a little easier to start, and to increase or decrease than the coke. If continuous fires are needed, this factor would be insignificant. Coke requires special burners. A smaller number of fires are needed than with charcoal and the cost of the equipment might be covered by the saving in fuel during the first season. The equipment should last many years. 


\section{FIRE-CURING TESTS ON STALK TOBACCO}

\section{J. S. OWEns}

Growers of shade tobacco consider artificial heat indispensible for hastening curing and for prevention of pole sweat. An occasional grower of stalk tobacco uses charcoal fires in emergencies to prevent pole sweat, and on a very few farms, fires are used to hasten curing. This project was undertaken to determine the practicability and the effect upon quality of curing stalk tobacco with methods similar to those that the shade growers believe essential.

In 1928, one or more sheds were fired on each of nine farms. Four of the growers raised Havana and five Broadleaf. Immediately after filling, most of the sheds were heated for about fortyeight hours, or until the leaves became wilted. Open or covered charcoal fires were used and readings of $20^{\circ} \mathrm{F}$. above outside temperature maintained, except during hot days. Every shed was fired from one to three times to dry off the leaves during the dampest spells. Because of the varying condition of the tobacco and weather, a uniform plan of heating and ventilation could not be followed.

Only a small amount of pole sweat existed in any of the sheds fired, although the season was exceptionally favorable to such damage and heavy losses from sweat were general. Where sweat occurred in the fired sheds, either the firing had been delayed until weather conditions became bad or the fires were not maintained long enough to dry the leaves thoroughly. Injury from overfiring was not indicated, even in the sheds that were heated a total of 150 hours.

The weather conditions were much more favorable for curing without artificial heat in 1929. Two growers of Broadleaf and four growers of Havana fired to hasten curing, almost regardless of weather conditions. Again the tobacco appeared to be of good quality. However, no comparisons with what would have resulted without firing were possible.

In 1930 comparative tests were conducted on three farms. In each case tobacco was taken from the field and portions stored in two similar sheds on the same day. One of each pair of sheds was heated immediately and kept about $20^{\circ} \mathrm{F}$. above outside temperature for approximately 48 hours, at which time the leaves were

Note: The tests and observations on which this report is based were made with the assistance of R. G. Tryon and Dan Andrews, Glastonbury; R. E. Case, West Granby; S. R. Spencer, Suffield; Theodore Hurlbut, Somers : Horace Pease and DeCarli Brothers, Ellington; Harry N. Farnham and J. E. Shepard, East Windsor; and John M. Herr, East Hartford. The writer wishes to express appreciation for the splendid coöperation given by these men. 
well wilted. The same sheds were again heated a week later for a period of 12 to 24 hours, to remove the moisture during a damp spell.

The sorting records for each of the three farms are as follows:

John M. Herr, East Hartford (Broadleaf)

\begin{tabular}{|c|c|c|c|c|c|c|c|c|c|c|c|}
\hline & Acre yield & $\overparen{L}$ & M & LS & $\begin{array}{l}\text { Perc } \\
\text { SS }\end{array}$ & $\begin{array}{c}\text { ntage } \\
\text { LD }\end{array}$ & $\begin{array}{c}\text { of grades } \\
\text { No.2S }\end{array}$ & $\mathrm{F}$ & B & $\overline{\mathrm{LT}}$ & $\begin{array}{l}\text { Grade } \\
\text { index }\end{array}$ \\
\hline & 2122 & 2.3 & 8.2 & 18.9 & 1.3 & 27.5 & 23.3 & 4.9 & 3.4 & 10.3 & .372 \\
\hline Not fired & 1908 & $\ldots$ & 3.5 & 13.6 & 3.9 & 27.1 & 22.4 & $\ldots$ & 12.5 & 17.1 & .313 \\
\hline
\end{tabular}

Harry N. Farnham, East Windsor (Broadleaf)

\begin{tabular}{|c|c|c|c|c|c|c|c|c|c|c|c|}
\hline & Acre yield & & $M$ & LS & & $D^{\text {of }}$ & & $\mathrm{F}$ & B & $\mathrm{T}$ & \\
\hline & & $\begin{array}{l}2.4 \\
9.6\end{array}$ & & & & $\begin{array}{l}31.7 \\
24.9\end{array}$ & $\begin{array}{r}20.5 \\
8.1\end{array}$ & $\begin{array}{l}9.8 \\
9.4\end{array}$ & & $\begin{array}{l}7.9 \\
9.6\end{array}$ & .44 \\
\hline
\end{tabular}

S. R. Spencer, Suffield (Havanı Seed)

\begin{tabular}{lccrrrrrrrrrr}
\multicolumn{1}{c}{ Acre yield d } & & L & M & LS & SS & LD & No.DS & F & B & T & Grade \\
index \\
Fired & 1412 & 17.3 & 8.5 & 27.8 & $\ldots$ & 37.2 & $\ldots$ & 9.2 & $\ldots$ & $\ldots$ & .512 \\
Not fired & 1412 & 20.1 & 12.2 & 24.2 & $\ldots$ & 36.3 & $\ldots$ & 7.2 & $\ldots$ & $\ldots$ & .536
\end{tabular}

Changes in the quality that can be credited to the firing are neither consistent nor large. The season was abnormally dry throughout. Some tobacco cured too rapidly without artificial heat, and pole sweat was almost unknown. It is hardly possible to deduce from the one season's experience what effect there would be upon quality in a season with an average range of humidity. The results did not seem to justify firing last year, but the fact that there was little, if any, injury from firing under the extremely dry conditions, would indicate that possible damage to the crop is not the most important factor in deciding whether firing should be done. 


\section{APPENDIX}

Fertilizer Forifulas Used in the Tests of 1930 Referred to in THIS REPort

N1.

Standard Formula; 200 Pounds Nitrogen

\begin{tabular}{|c|c|c|c|c|c|}
\hline & & & & & \\
\hline Name & Lbs. per acre & $\mathrm{N}$ & $\mathrm{P}_{2} \mathrm{O}_{5}$ & $\mathrm{~K}_{2} \mathrm{O}$ & $\mathrm{MgO}$ \\
\hline Cottonseed meal & 1765. & 120 & 52.9 & 35.3 & 12.4 \\
\hline astor pomace . . & 741. & 40 & 14.8 & 7.4 & 5.9 \\
\hline ate of soda & 260. & 40 & & & \\
\hline potash ........ & 163.8 & & & 78.6 & \\
\hline onate of potash ..... & 122.8 & & & 78.7 & \\
\hline gnesian lime ......... & 400. & & & & 100. \\
\hline Total .... & 3452.6 & 200 & 67.7 & 200. & 118.3 \\
\hline
\end{tabular}

N2.

One-Half of the Nitrogen in Nitrate of Soda

Cottonseed meal ........

Castor pomace .........

Nitrate of soda ..........

Sulfate of potash .......

Carbonate of potash .....

Double sulfate .........

$$
\text { Total }
$$

\begin{tabular}{rr}
1103. & 75 \\
463. & 25 \\
649.4 & 100 \\
65.1 & \\
122.8 & \\
243.8 & \\
\hline 2647.1 & -200
\end{tabular}

33.1

$9.3 \quad 4.6$

31.3

78.6

63.4

38.3

N8.

One-Half of the Nitrogen in Urea

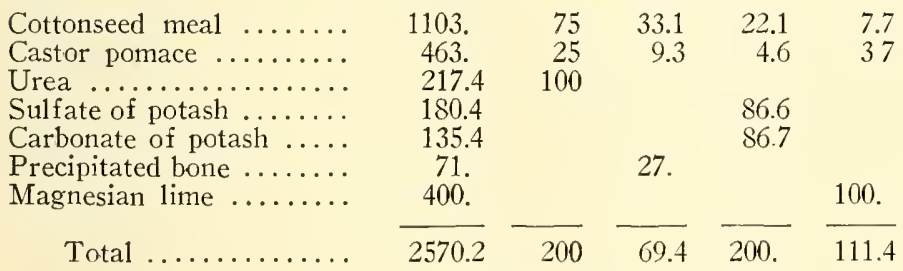

N9.

Urea ...............

Carbonate of potash .....

Sulfate of potash ........

Precipitated bone .......

Magnesian lime

Total
All Nitrogen in Urea

434. 200

$154 . \quad 100$

$200 . \quad 100$.

180.

67.7

400.

$\overline{1368 .} \quad \overline{200} \overline{67.7} \overline{200 .} \quad \overline{100 .}$

N18. Standard Formula; Calcium Nitrate Substituted for Nitrate of Soda

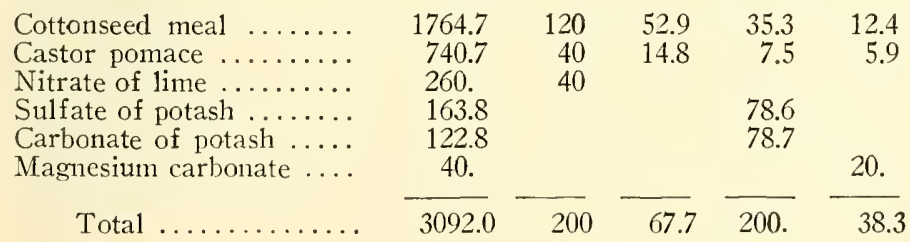


N28. Standard Formula ; 200 pounds Nitrogen

\begin{tabular}{|c|c|c|c|c|c|c|}
\hline Name & Lbs. per acre & $\mathrm{N}$ & $\mathrm{P}_{2} \mathrm{O}_{5}$ & $\mathrm{~K}_{2} \mathrm{O}$ & $\mathrm{MgO}$ & $\mathrm{CaO}$ \\
\hline $\begin{array}{l}\text { Cottonseed meal } \ldots \ldots \ldots \\
\text { Castor pomace } \ldots \ldots \ldots \\
\text { Nitrate of lime } \ldots \ldots \ldots \\
\text { Sulfate of potash } \ldots \ldots \\
\text { Carbonate of potash } \ldots \ldots \\
\text { Magnesium carbonate } \ldots \\
\text { Precipitated bone }\end{array}$ & $\begin{array}{c}1764.7 \\
740.7 \\
260 . \\
163.8 \\
122.8 \\
36 . \\
243\end{array}$ & $\begin{array}{r}120 \\
40 \\
40\end{array}$ & $\begin{array}{l}52.9 \\
14.8\end{array}$ & $\begin{array}{r}35.3 \\
7.4 \\
78.6 \\
78.7\end{array}$ & $\begin{array}{r}12.4 \\
5.9\end{array}$ & $\begin{array}{r}5.3 \\
5.9 \\
72.8 \\
0.3\end{array}$ \\
\hline ecipitated Done... . & 243. & & 92.5 & & & 09.4 \\
\hline Total ... & 3331. & 200 & 160. & 200. & 36. & 193.7 \\
\hline
\end{tabular}

N29. One-Hundred Pounds Nitrogen from Nitrophoska

\begin{tabular}{|c|c|c|c|c|c|c|}
\hline \multirow{6}{*}{$\begin{array}{l}\text { Cottonseed meal } \\
\text { Castor pomace . } \\
\text { Nitrophoska ... }\end{array}$} & \multirow{6}{*}{$\begin{array}{c}1103 . \\
463 . \\
645.2 \\
46.3 \\
79.2 \\
50 .\end{array}$} & \multirow{3}{*}{$\begin{array}{r}75 \\
25\end{array}$} & \multirow{2}{*}{$\begin{array}{r}33.1 \\
9.3\end{array}$} & \multirow{2}{*}{$\begin{array}{r}22.1 \\
4.6\end{array}$} & \multicolumn{2}{|l|}{7.7} \\
\hline & & & & & 3.7 & 3.7 \\
\hline & & & 100. & 122.6 & 0.7 & 3.5 \\
\hline & & & 17.6 & & & 20.8 \\
\hline & & & & 50.7 & & \\
\hline & & & & & 25. & \\
\hline Total & 2386.7 & 200 & 160. & 200 & 37.1 & \\
\hline
\end{tabular}

N30. Maximum Nitrogen from Nitrophoska

\begin{tabular}{|c|c|c|c|c|c|}
\hline $\begin{array}{l}\text { Nitrophoska } \ldots \ldots \ldots \ldots \\
\text { Urea ...................... } \\
\text { Magnesium carbonate .... }\end{array}$ & $\begin{array}{l}1052.6 \\
80 . \\
73 .\end{array}$ & $\begin{array}{r}163.2 \\
36.8\end{array}$ & 163.2 & 200. & 36.5 \\
\hline Total & 1205.6 & 200. & 1632 & 200. & 37. \\
\hline
\end{tabular}

K1. Basal Ration with All Mineral Potash in Sulfate of Potash $\begin{array}{llllll}\text { Cottonseed meal ....... } & 1765 . & 120 & 52.9 & 35.3 & 12.4\end{array}$

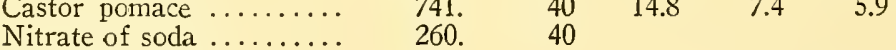
Sulfate of potash ....... 327. Magnesian lime ....... 400 . $-\quad-116$. Total .......... $3493 . \quad 200 \quad 67.7 \quad 200 . \quad 134.3$

K5.

All Mineral Potash in Carbonate

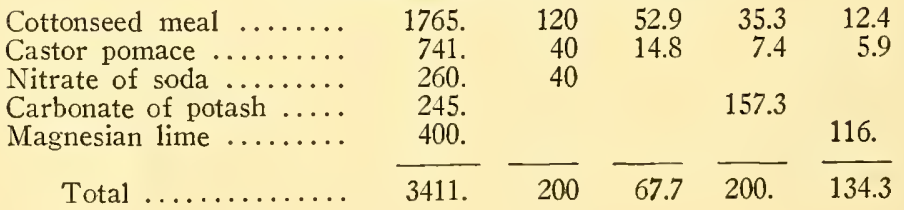


K7. Three-Fourths of the Mineral Potash in Nitrate; One-Third in Carbonate

\begin{tabular}{|c|c|c|c|c|c|}
\hline Name & Lbs. per acre & $\mathrm{N}$ & $\mathrm{P}_{2} \mathrm{O}_{5}$ & $\mathrm{~K}_{2} \mathrm{O}$ & $\mathrm{MgO}$ \\
\hline Cottonseed meal & 1765. & 120 & 52.9 & 35.3 & 12.4 \\
\hline Castor pomace ... & 741. & 40 & 14.8 & 7.4 & 5.9 \\
\hline Nitrate of potash.. & 325. & 40 & & 143. & \\
\hline Carbonate of potash & 22. & & & 14.3 & \\
\hline Magnesian lime...$\ldots \ldots$ & 400. & & & & 116. \\
\hline Total & 3253. & 200 & 67.7 & 200. & 134.3 \\
\hline
\end{tabular}

K8. Mineral Potash Divided Equally Between Sulfate and Carbonate of Potash

\begin{tabular}{|c|c|c|c|c|c|}
\hline \multirow{5}{*}{$\begin{array}{l}\text { Cottonseed meal } \ldots \ldots \ldots \\
\text { Castor pomace } \ldots \ldots \ldots \\
\text { Nitrate of soda } \ldots \ldots \ldots \\
\text { Sulfate of potash } \ldots \ldots \\
\text { Carbonate of potash } \\
\text { Magnesian lime } \ldots . . .\end{array}$} & 1765. & 120 & 52.9 & 35.3 & \\
\hline & 741. & 40 & 14.8 & 7.4 & \\
\hline & 260. & 40 & & & \\
\hline & 163. & & & 78.6 & \\
\hline & 400. & & & & 116. \\
\hline Total & 3452. & 200 & 67.7 & 200 & \\
\hline
\end{tabular}

K9. Mineral Potash Divided Equally Between Sulfate, Nitrate and Carbonate of Potash

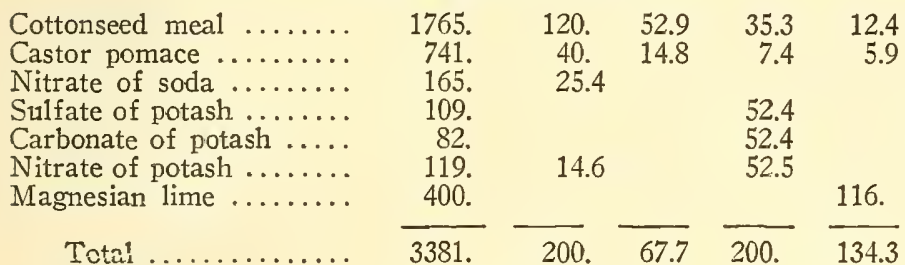

K11.

No Mineral Potash

Cottonseed meal ........

Castor pomace ..........

Nitrate of soda .........

Magnesian lime ..........

\begin{tabular}{|c|c|c|c|}
\hline $\begin{array}{r}1765 . \\
741 . \\
260 . \\
400 .\end{array}$ & $\begin{array}{r}120 \\
40 \\
40\end{array}$ & $\begin{array}{l}52.9 \\
14.8\end{array}$ & $\begin{array}{r}35.3 \\
7.4\end{array}$ \\
\hline 3166. & 200 & 67.7 & 42.7 \\
\hline
\end{tabular}

$\mathrm{K} 12$.

Potash Reduced to 100 Pounds

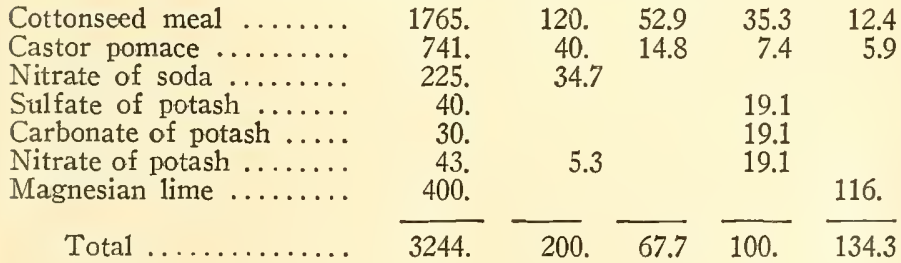


K13. Three Hundred Pounds Potash, Equally from Carbonate, Sulfate, and Nitrate

\begin{tabular}{|c|c|c|c|c|c|}
\hline Name & $\overbrace{\text { Lbs. per acre }}$ & $\mathrm{N}$ & $\begin{array}{r}\text { Nutrie } \\
\mathrm{N}_{2} \mathrm{O}_{5}\end{array}$ & 5 per & $\mathrm{MgO}$ \\
\hline ottonseed meal ...... & 1765. & 120. & 52.9 & 35.3 & 12.4 \\
\hline astor pomace ......... & 741. & 40. & 14.8 & 7.4 & 5.9 \\
\hline ate of soda $\ldots . . .$. & 105. & 16.1 & & & \\
\hline ate of potash $\ldots . .$. . & 195. & 23.9 & & 85.7 & \\
\hline onate of potash ..... & 134. & & & 85.8 & \\
\hline ate of potash ......... & 179. & & & 85.8 & \\
\hline gnesian lime....$\ldots$ & 400. & & & & 116. \\
\hline Total & 3519. & 200. & 67.7 & 300. & 134.3 \\
\hline
\end{tabular}

K14. Two Hundred Pounds Potash, All in Stems

Cottonseed meal ....... 1529. $104 \quad 45.9 \quad 30.5 \quad 10.7$

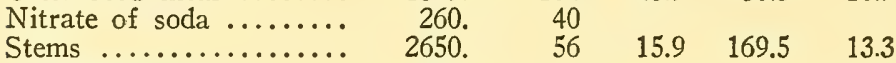

$\begin{array}{lrrrrr}\text { Stems } & \\ \text { Magnesian lime } \ldots \ldots \ldots \ldots & 2650 . & 56 & 15.9 & 169.5 & 13.3 \\ \end{array}$

Total ........... $\overline{4839 .} \quad \overline{200} \quad \overline{61.8} \overline{200 .} \quad \overline{140 .}$

K15. Two Hundred Pounds Potash in Cotton Hull Ashes

Cottonseed meal ....... 1765. $120 \quad 52.9 \quad 35.3 \quad 12.4$

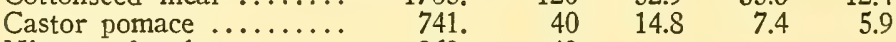

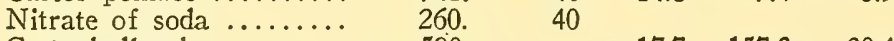

$\begin{array}{lllll}\text { Cottonhull ash } \ldots \ldots \ldots \ldots & 590 . & 17.7 & 157.3 & 30.4\end{array}$

Total .......... $\overline{3356 .} \quad \overline{200} \quad \overline{85.4} \quad \overline{200 .} \overline{48.7}$ 




\section{University of}

Connecticut

\section{Libraries}


8.

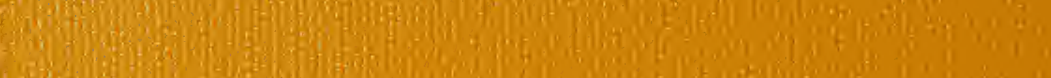

ate

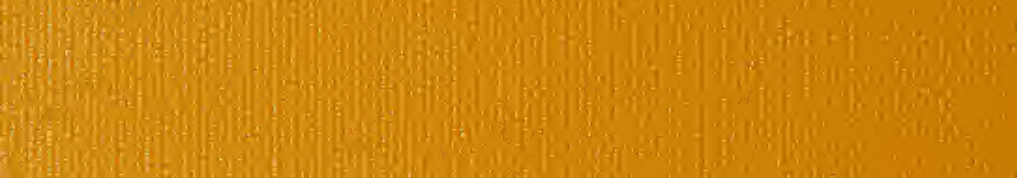

a (2)

(i)

ing

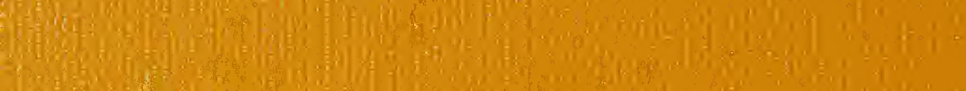

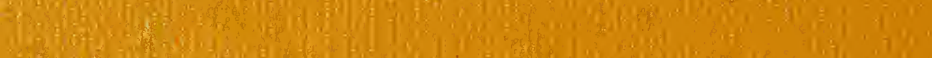

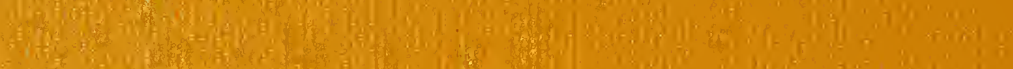

at

(1)

S.

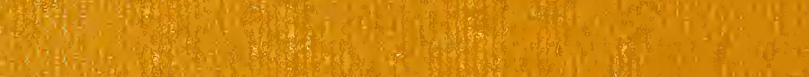

P.

W.

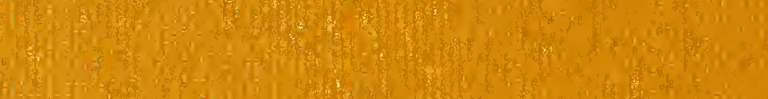

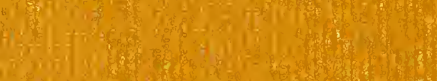

(1)

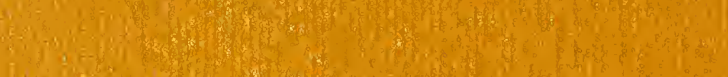

d.

a

(25)

(f)

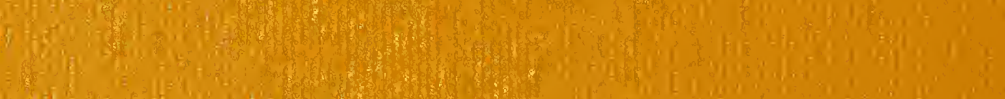

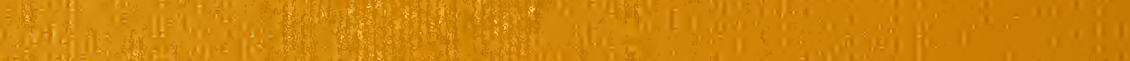

a

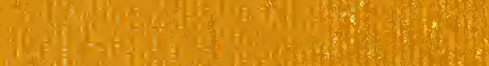

Nof

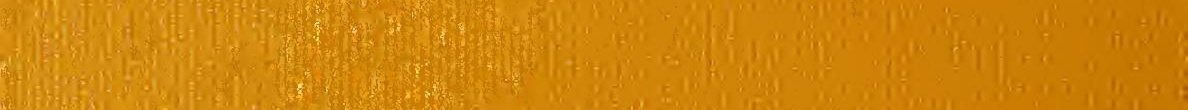

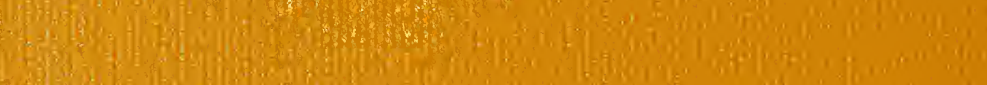
Hef

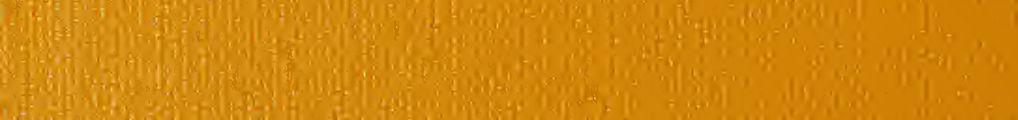
fore ISI

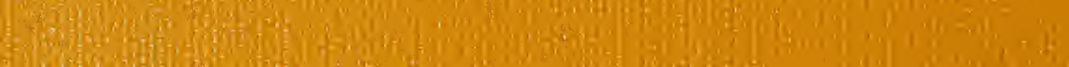

